\title{
\#USES
}

Prepared as part of the U.S. Geological Survey Cooperative Water Program and the National Streamflow Information Program

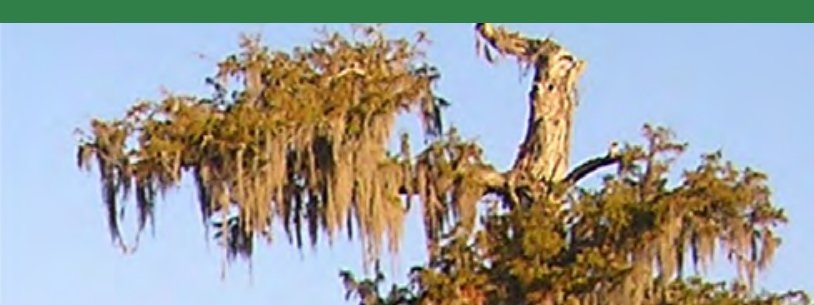

Hrufo ogtc Conditions mining Warider Year 2008

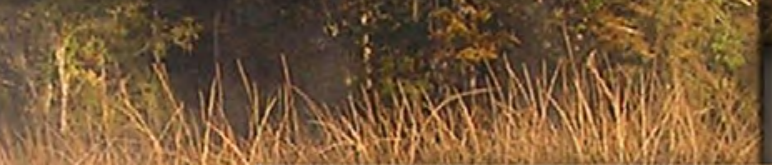

Scientific Investigations Report 2010-5115

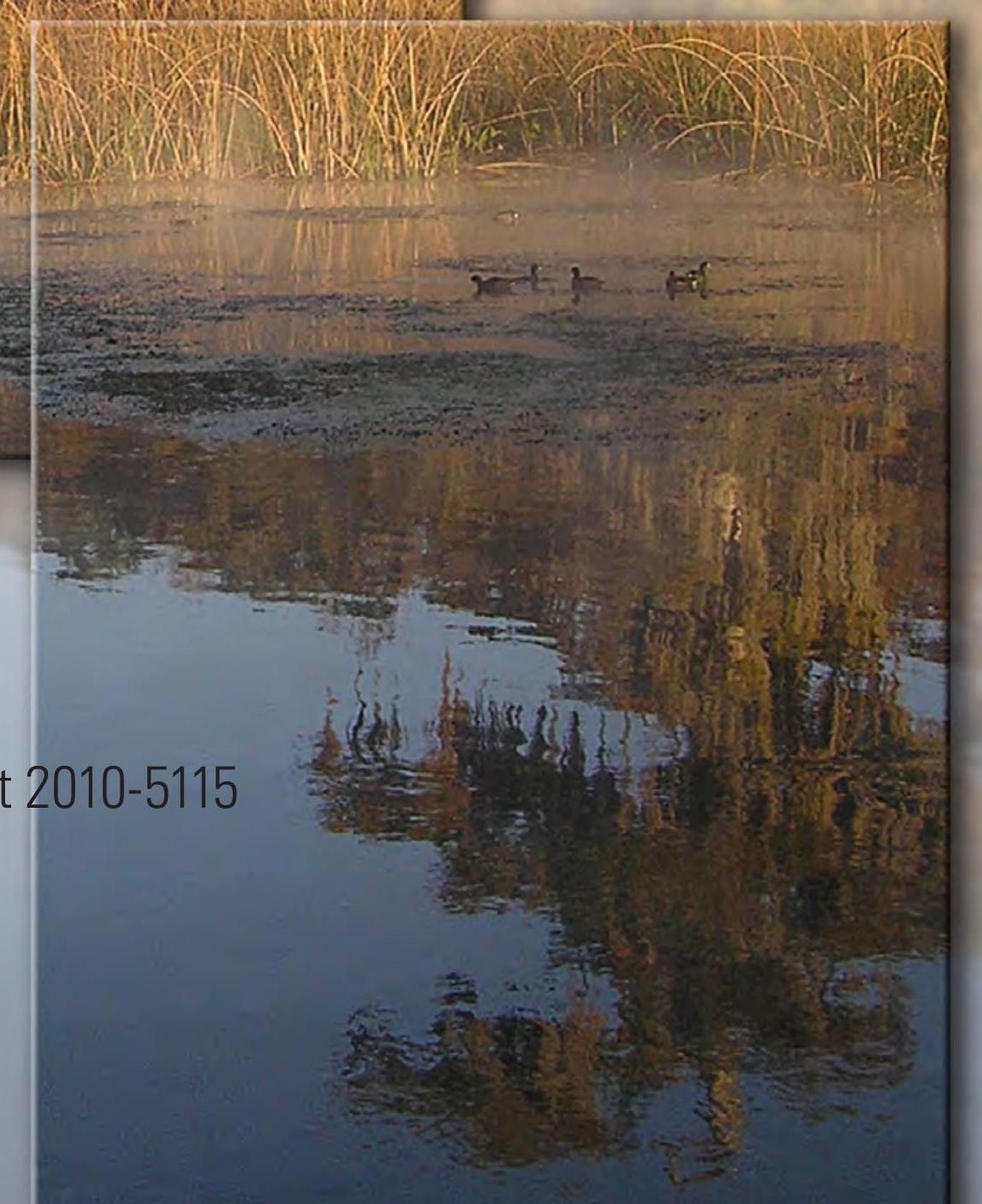

U.S. Department of the Interior U.S. Geological Survey 
Cover. Wakulla River at Wakulla Springs State Park. Photograph by Hal Davis, U.S. Geological Survey. 


\section{Hydrologic Conditions in Florida during Water Year 2008}

By Richard J. Verdi, Sandra L. Holt, Ronald B. Irvin, and David L. Fulcher

Prepared as part of the

U.S. Geological Survey Cooperative Water Program and the

National Streamflow Information Program

Scientific Investigations Report 2010-5115 


\title{
U.S. Department of the Interior \\ KEN SALAZAR, Secretary \\ U.S. Geological Survey \\ Marcia K. McNutt, Director
}

\section{U.S. Geological Survey, Reston, Virginia: 2010}

\author{
For more information on the USGS — the Federal source for science about the Earth, its natural and living resources, \\ natural hazards, and the environment, visit http://www.usgs.gov or call 1-888-ASK-USGS \\ For an overview of USGS information products, including maps, imagery, and publications, \\ visit http://www.usgs.gov/pubprod \\ To order this and other USGS information products, visit http://store.usgs.gov
}

Any use of trade, product, or firm names is for descriptive purposes only and does not imply endorsement by the U.S. Government.

Although this report is in the public domain, permission must be secured from the individual copyright owners to reproduce any copyrighted materials contained within this report.

Suggested citation:

Verdi, R.J., Holt, S.L., Irvin, R.B., and Fulcher, D.L., 2010, Hydrologic conditions in Florida during Water Year 2008: U.S. Geological Survey Scientific Investigations Report 2010-5115, 52 p 


\section{Contents}

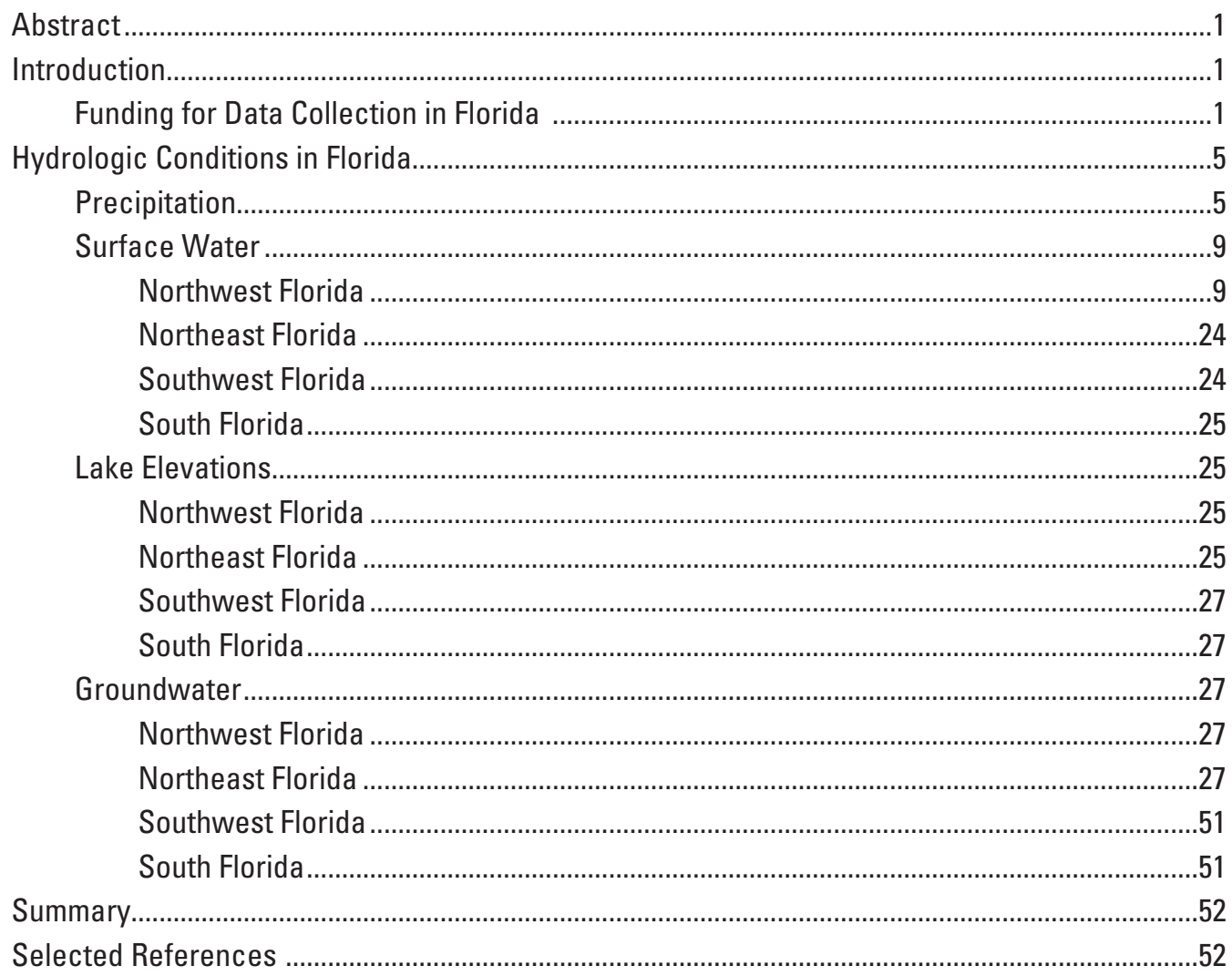

\section{Figures}

1. Map showing delineation of geographic monitoring regions in Florida ............................2

2. Map showing locations of monitoring stations in Florida ....................................................

3. Example of the monthly observed precipitation maps provided by the National Oceanic and Atmospheric Administration, National Weather Service, August 2008 .......6

4. Example of the monthly percentage of normal precipitation maps provided by the National Oceanic and Atmospheric Administration, National Weather Service, August 2008.

5. Examples of the weekly drought monitor maps provided by the National Oceanic and Atmospheric Administration, National Weather Service.

6-60. Figures showing-

6. Suwannee River at Branford water year 2008 monthly mean discharge compared to the maximum, minimum, and mean monthly mean discharge for the period 1931-2008, and the monthly mean discharge for the period October 1998 to September 2008

7. Santa Fe River at Worthington Springs water year 2008 monthly mean discharge compared to the maximum, minimum, and mean monthly mean discharge for the period 1932-2008, and the monthly mean discharge for the period October 1998 to September 2008 
8. Steinhatchee River near Cross City water year 2008 monthly mean discharge compared to the maximum, minimum, and mean monthly mean discharge for the period 1950-2008, and the monthly mean discharge for the period October 1998 to September 2008

9. Ochlockonee River near Havana water year 2008 monthly mean discharge compared to the maximum, minimum, and mean monthly mean discharge for the period 1926-2008, and the monthly mean discharge for the period October 1998 to September 2008.

10. Chipola River near Altha water year $\mathbf{2 0 0 8}$ monthly mean discharge compared to the maximum, minimum, and mean monthly mean discharge for the period 1913-2008, and the monthly mean discharge for the period October 1998 to September 2008.

11. Shoal River near Crestview water year 2008 monthly mean discharge compared to the maximum, minimum, and mean monthly mean discharge for the period 1938-2008, and the monthly mean discharge for the period October 1998 to September 2008

12. Escambia River near Century water year $\mathbf{2 0 0 8}$ monthly mean discharge compared to the maximum, minimum, and mean monthly mean discharge for the period 1934-2008, and the monthly mean discharge for the period October 1998 to September 2008.

13. St. Mary's River near Macclenny water year 2008 monthly mean discharge compared to the maximum, minimum, and mean monthly mean discharge for the period 1927-2008, and the monthly mean discharge for the period October 1998 to September 2008

14. St. John's River near Cocoa water year 2008 monthly mean discharge compared to the maximum, minimum, and mean monthly mean discharge for the period 1954-2008, and the monthly mean discharge for the period October 1998 to September 2008

15. St. John's River near De Land water year 2008 monthly mean discharge compared to the maximum, minimum, and mean monthly mean discharge for the period 1934-2008, and the monthly mean discharge for the period October 1998 to September 2008 ...

16. Ocklawaha River near Conner water year 2008 monthly mean discharge compared to the maximum, minimum, and mean monthly mean discharge for the period 1930-2008, and the monthly mean discharge for the period October 1998 to September 2008

17. Fisheating Creek at Palmdale water year 2008 monthly mean discharge compared to the maximum, minimum, and mean monthly mean discharge for the period 1931-2008, and the monthly mean discharge for the period October 1998 to September 2008.

18. Reedy Creek near Vineland water year 2008 monthly mean discharge compared to the maximum, minimum, and mean monthly mean discharge for the period 1966-2008, and the monthly mean discharge for the period October 1998 to September 2008.

19. Arbuckle Creek near De Soto City water year 2008 monthly mean discharge compared to the maximum, minimum, and mean monthly mean discharge for the period 1939-2008, and the monthly mean discharge for the period October 1998 to September 2008.

20. Withlacoochee River at Trilby water year 2008 monthly mean discharge compared to the maximum, minimum, and mean monthly mean discharge for the period 1928-2008, and the monthly mean discharge for the period October 1998 to September 2008 
21. Little Withlacoochee River at Rerdell water year 2008 monthly mean discharge compared to the maximum, minimum, and mean monthly mean discharge for the period 1958-2008, and the monthly mean discharge for the period October 1998 to September 2008

22. Withlacoochee River near Holder water year 2008 monthly mean discharge compared to the maximum, minimum, and mean monthly mean discharge for the period 1928-2008, and the monthly mean discharge for the period October 1998 to September 2008

23. Peace River at Arcadia water year 2008 monthly mean discharge compared to the maximum, minimum, and mean monthly mean discharge for the period 1932-2008, and the monthly mean discharge for the period October 1998 to September 2008

24. Myakka River near Sarasota water year 2008 monthly mean discharge compared to the maximum, minimum, and mean monthly mean discharge for the period 1937-2008, and the monthly mean discharge for the period October 1998 to September 2008

25. Alafia River at Lithia water year $\mathbf{2 0 0 8}$ monthly mean discharge compared to the maximum, minimum, and mean monthly mean discharge for the period 1933-2008, and the monthly mean discharge for the period October 1998 to September 2008

26. Hillsborough River near Zephyrhills water year 2008 monthly mean discharge compared to the maximum, minimum, and mean monthly mean discharge for the period 1940-2008, and the monthly mean discharge for the period October 1998 to September 2008

27. Anclote River near Elfers water year 2008 monthly mean discharge compared to the maximum, minimum, and mean monthly mean discharge for the period 1947-2008, and the monthly mean discharge for the period October 1998 to September 2008.

28. St. Lucie Canal below S-308 near Port Mayaca water year 2008 monthly mean discharge compared to the maximum, minimum, and mean monthly mean discharge for the period 1931-2008, and the monthly mean discharge for the period October 1998 to September 2008

29. Caloosahatchee River at S-79 near Olga water year 2008 monthly mean discharge compared to the maximum, minimum, and mean monthly mean discharge for the period 1966-2008, and the monthly mean discharge for the period October 1998 to September 2008

30. West Palm Beach Canal at S-352 at Canal Point water year 2008 monthly mean discharge compared to the maximum, minimum, and mean monthly mean discharge for the period 1940-2008, and the monthly mean discharge for the period October 1998 to September 2008

31. Hillsboro Canal below S-351 near South Bay water year 2008 monthly mean discharge compared to the maximum, minimum, and mean monthly mean discharge for the period 1957-2008, and the monthly mean discharge for the period October 1998 to September 2008

32. North New River Canal below S-2 and S-351 near South Bay water year 2008 monthly mean discharge compared to the maximum, minimum, and mean monthly mean discharge for the period 1957-2008, and the monthly mean discharge for the period October 1998 to September 2008

33. Miami Canal at S-354 and S-3 at Lake Harbor water year 2008 monthly mean discharge compared to the maximum, minimum, and mean monthly mean discharge for the period 1958-2008, and the monthly mean discharge for the period October 1998 to September 2008 
34. Industrial Canal at Clewiston water year 2008 monthly mean discharge compared to the maximum, minimum, and mean monthly mean discharge for the period 1976-2008, and the monthly mean discharge for the period October 1998 to September 2008

35. Lake Talquin near Bloxham water year 2008 monthly mean elevation compared to the maximum, minimum, and mean monthly mean elevation for the period 1930-2008, and the monthly mean elevation for the period October 1998 to September 2008 ..

36. Lake Minnehaha at Clermont water year 2008 monthly mean elevation compared to the maximum, minimum, and mean monthly mean elevation for the period 1947-2008, and the monthly mean elevation for the period October 1998 to September 2008

37. Moon Lake in Pasco County water year 2008 monthly mean elevation compared to the maximum, minimum, and mean monthly mean elevation for the period 1965-2008, and the monthly mean elevation for the period October 1998 to September 2008 .

38. Lake Okeechobee water year 2008 monthly mean elevation compared to the maximum, minimum, and mean monthly mean elevation for the period 1912-2008, and the monthly mean elevation for the period October 1998 to September 2008.

39. USGS observation well 422A near Greenhead water year 2008 daily maximum water level compared to historical water levels for the period October 1983 to September 2008, and the Seasonal Kendall Trend Test for the period October 1983 to September 2008 .

40. USGS benchmark well near Crawfordville water year 2008 daily maximum water level compared to historical water levels for the period October 1983 to September 2008, and the Seasonal Kendall Trend Test for the period October 1983 to September 2008 .

41. DOT-41 observation well at Inverness water year 2008 daily maximum water level compared to historical water levels for the period October 1983 to September 2008, and the Seasonal Kendall Trend Test for the period October 1983 to September 2008 .

42. College Street well at Leesburg water year $\mathbf{2 0 0 8}$ daily maximum water level compared to historical water levels for the period October 1983 to September 2008, and the Seasonal Kendall Trend Test for the period October 1983 to September 2008.

43. Lake Oliver deep well near Vineland water year 2008 daily maximum water level compared to historical water levels for the period October 1983 to September 2008, and the Seasonal Kendall Trend Test for the period October 1983 to September 2008.

44. $\quad$ R-47 at Orlo Vista water year 2008 daily maximum water level compared to historical water levels for the period October 1983 to September 2008, and the Seasonal Kendall Trend Test for the period October 1983 to September 2008........34

45. P-49 well near Frostproof water year 2008 daily maximum water level compared to historical water levels for the period October 1983 to September 2008, and the Seasonal Kendall Trend Test for the period October 1983 to September 2008.

46. USGS observation well H-15A near Palmdale water year 2008 daily maximum water level compared to historical water levels for the period October 1983 to September 2008, and the Seasonal Kendall Trend Test for the period October 1983 to September 2008. 
47. State Highway 577 well near San Antonio water year 2008 daily maximum water level compared to historical water levels for the period October 1983 to September 2008, and the Seasonal Kendall Trend Test for the period October 1983 to September 2008.

48. Weeki Wachee well near Weeki Wachee water year 2008 daily maximum water level compared to historical water levels for the period October 1983 to September 2008, and the Seasonal Kendall Trend Test for the period October 1983 to September 2008

49. ROMP 57 Floridan well near Lake Wales water year 2008 daily maximum water level compared to historical water levels for the period October 1983 to September 2008, and the Seasonal Kendall Trend Test for the period October 1983 to September 2008

50. Turner well near Brandon water year 2008 daily maximum water level compared to historical water levels for the period October 1983 to September 2008, and the Seasonal Kendall Trend Test for the period October 1983 to September 2008......40

51. Kibler deep well $26 \mathrm{~B}$ near Bethany water year 2008 daily maximum water level compared to historical water levels for the period October 1983 to September 2008, and the Seasonal Kendall Trend Test for the period October 1983 to September 2008

52. Sarasota well 9 near Sarasota water year 2008 daily maximum water level compared to historical water levels for the period October 1983 to September 2008, and the Seasonal Kendall Trend Test for the period October 1983 to September 2008

53. Marshall deep well near Gardner water year 2008 daily maximum water level compared to historical water levels for the period October 1983 to September 2008, and the Seasonal Kendall Trend Test for the period October 1983 to September 2008

54. USGS observation well S-196A near Homestead water year 2008 daily maximum water level compared to historical water levels for the period October 1983 to September 2008, and the Seasonal Kendall Trend Test for the period October 1983 to September 2008

55. USGS observation well PB-683 near West Palm Beach water year 2008 daily maximum water level compared to historical water levels for the period October 1983 to September 2008, and the Seasonal Kendall Trend Test for the period October 1983 to September 2008

56. USGS observation well C-496 water year 2008 daily maximum water level compared to historical water levels for the period October 1983 to September 2008, and the Seasonal Kendall Trend Test for the period October 1983 to September 2008

57. USGS observation well L-2194 water year 2008 daily maximum water level compared to historical water levels for the period October 1983 to September 2008, and the Seasonal Kendall Trend Test for the period October 1983 to September 2008

58. USGS observation well L-729 water year 2008 daily maximum water level compared to historical water levels for the period October 1983 to September 2008, and the Seasonal Kendall Trend Test for the period October 1983 to September 2008

59. USGS observation well L-1993 water year 2008 daily maximum water level compared to historical water levels for the period October 1983 to September 2008, and the Seasonal Kendall Trend Test for the period October 1983 to September 2008.

60. USGS observation well L-2434 water year 2008 daily maximum water level compared to historical water levels for the period October 1983 to September 2008, and the Seasonal Kendall Trend Test for the period October 1983 to September 2008 ......50 


\section{Tables}

1. Relation of period-of-record mean annual discharge to mean discharge for the 2007 and 2008 water years.

2. Stations reaching record-low monthly mean discharge and month(s) of occurrence during the 2008 water year and their previous record and year of occurrence

3. Stations reaching record-high monthly mean discharge and month(s) of occurrence during the 2008 water year and their previous record and year of occurrence.

4. Peak discharges, river levels, and exceedance probabilities compared to period-of-record peak discharges, river levels, and exceedance probabilites for sites reaching period of record instantaneous peak discharges caused by Tropical Storm Fay.

\section{Conversion factors, abbreviations, acronyms, and datums}

\begin{tabular}{lll}
\multicolumn{1}{c}{ Multiply } & \multicolumn{1}{c}{ By } & \multicolumn{1}{c}{ To obtain } \\
\hline inch (in.) & 2.54 & centimeter $(\mathrm{cm})$ \\
foot $(\mathrm{ft})$ & 0.3048 & meter $(\mathrm{m})$ \\
square mile $\left(\mathrm{mi}^{2}\right)$ & 2.590 & square kilometer $\left(\mathrm{km}^{2}\right)$ \\
cubic foot per second $\left(\mathrm{ft}^{3} / \mathrm{s}\right)$ & 0.02832 & cubic meter per second $\left(\mathrm{m}^{3} / \mathrm{s}\right)$ \\
\hline
\end{tabular}

\begin{tabular}{l|l} 
ADR & Annual Data Report \\
$\mathrm{mg} / \mathrm{L}$ & milligrams per liter \\
NSIP & National Streamflow Information Program \\
NWISWeb & U.S. Geological Survey National Water Information System Webpage \\
SKTT & Seasonal Kendall Trend Test \\
USGS & U.S. Geological Survey
\end{tabular}

Vertical coordinate information is referenced to National Geodetic Vertical Datum of 1929 (NGVD 29).

Horizontal coordinate information is referenced to the North American Datum of 1983 (NAD 83).

Elevation, as used in this report, refers to distance above the vertical datum. 


\title{
Hydrologic Conditions in Florida during Water Year 2008
}

\author{
By Richard J. Verdi, Sandra L. Holt, Ronald B. Irvin, and David L. Fulcher
}

\section{Abstract}

Record-high and record-low hydrologic conditions occurred during water year 2008 (October 1, 2007-September 30,2008 ). Record-low levels were caused by a continuation of the 2007 water year drought conditions into the 2008 water year and persisting until summer rainfall. The gage at the Santa Fe River near Fort White site recorded record-low monthly mean discharges in October and November 2007. The previous records for this site were set in 1956 and 2002, respectively. Record-high conditions in northeast and northwest Florida were caused by the rainfall and runoff associated with Tropical Storm Fay. For example, St. Mary's River near Macclenny recorded a new record-high monthly mean discharge in August 2008. The previous record for this site was set in 1945. Lake Okeechobee in south Florida reached new minimum monthly mean lake levels since monitoring began in 1912 from October to March during the 2008 water year. Some wells throughout northwest and south Florida registered period-of-record lowest daily maximum water levels.

\section{Introduction}

This report describes data and hydrologic conditions throughout Florida during the 2008 water year - a recordsetting year for high and low precipitation, surface-water flows, lake elevations, and groundwater levels. Overall, the hydrologic conditions in Florida in 2008 varied from well below normal, caused by a continuation of the 2007 water year drought conditions, to above normal, caused by the landfall of Tropical Storm Fay in August. Record-low and record-high monthly mean discharge conditions were reported at several locations. Levels at Lake Okeechobee in south Florida reached record lows from October to March in the 2008 water year. Groundwater levels generally were below normal, although some sites were above normal during part of the year. Historically, Florida has been divided into four geographic monitoring regions (fig. 1): northwest, northeast, southwest, and south. The locations of the monitoring stations used in this report are identified in figure 2.

Prior to 1960, these data were published in various U.S. Geological Survey (USGS) water-supply papers and included water-related data collected by USGS during the water year (October 1 to September 30). In 1961, a series of annual reports, called "Water-Resources Data for Florida," was introduced that published only surface-water data. In 1964, a similar report was introduced for the purposes of publishing water-quality data. In 1975, the reports were changed to a single volume and expanded to publish data for surface water, water quality, and ground-water levels. These reports are listed at http://fl.water.usgs.gov/publications/bibliography/ bibliography.html\#S (within the alphabetical listing of entries that begin with "U.S. Geological Survey"). Formal publication of the annual report series was discontinued at the end of the 2005 water year upon activation of the Annual Data Report (ADR) database website. Reports for water years subsequent to 2005 are available at this website. This website facilitates the retrieval of data by hydrologic units or individual basins that cross State and county boundaries, and gives the user many options regarding the data and site locations of which they have interest. National data for discharge, lake and groundwater levels, and quality of water for the 2008 water year are accessible to the public on the USGS ADR website at http://wdr.water.usgs.gov/.

Current and historical data, including site information, daily values, statistics, and field measurements, are available for all monitoring sites on the National Water Information Webpage (NWISWeb) at http://waterdata.usgs.gov/fl/nwis/nwis. Incremental time-series data for past 10 to 15 years are available for many parameters (gage height, discharge, water temperature, specific conductance, and so forth) for many USGS stations since the evolution of electronic data loggers; computer systems have made it possible to store and provide access to such data. The Instantaneous Data Archive is available at: http://ida.water. usgs.gov/ida/index_usgs.cfm.

\section{Funding for Data Collection in Florida}

Funding to provide hydrologic data to the public primarily comes from three Federal sources: (1) the USGS Cooperative Water Program in which Federal, State, and local agencies share in the costs of the monitoring stations with the USGS; (2) other agency funds; and (3) the National Streamflow Information Program (NSIP). The NSIP provides some Federal funding for gages with the following critical interests: 


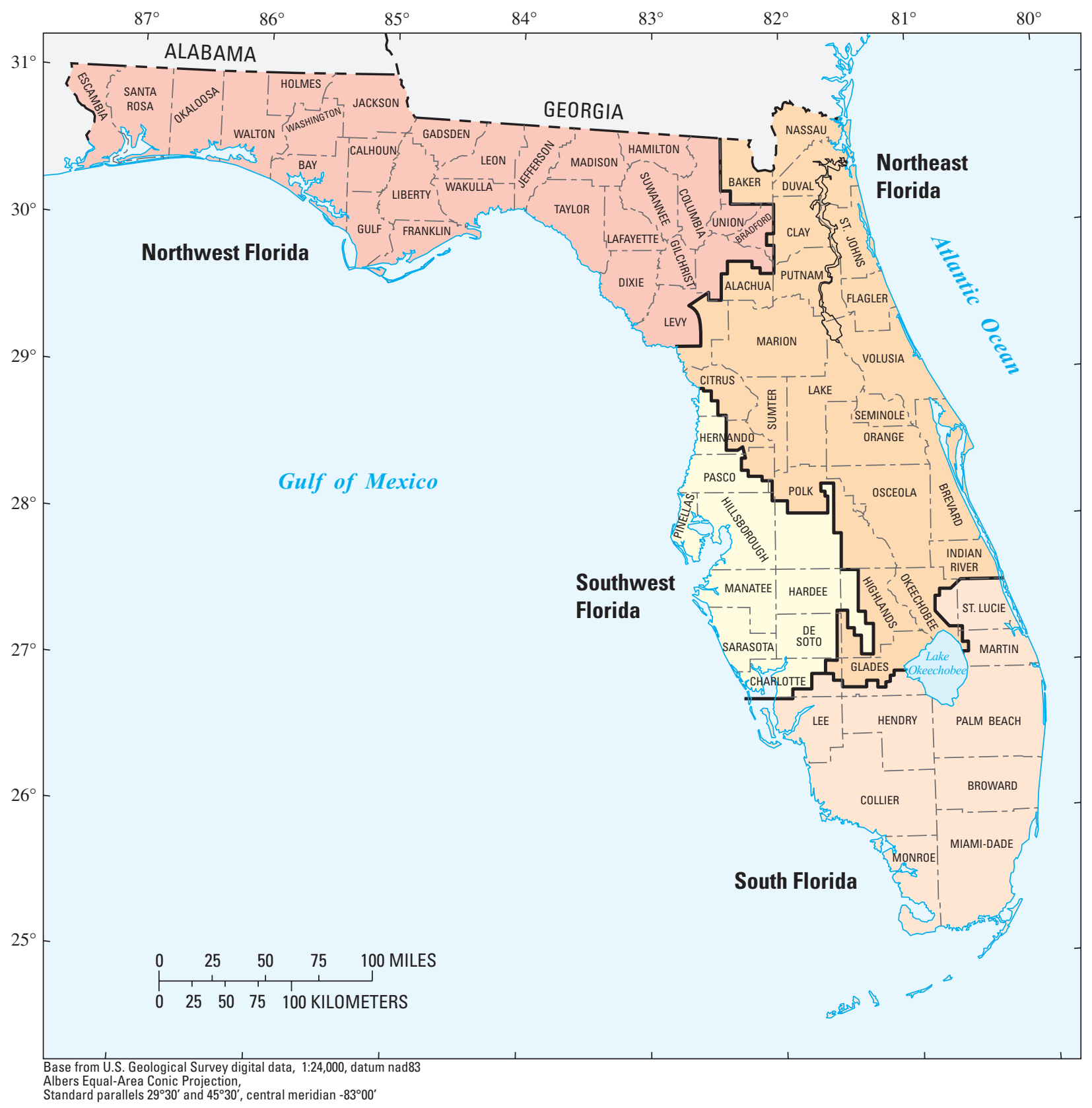

Figure 1. Delineation of geographic monitoring regions in Florida. 


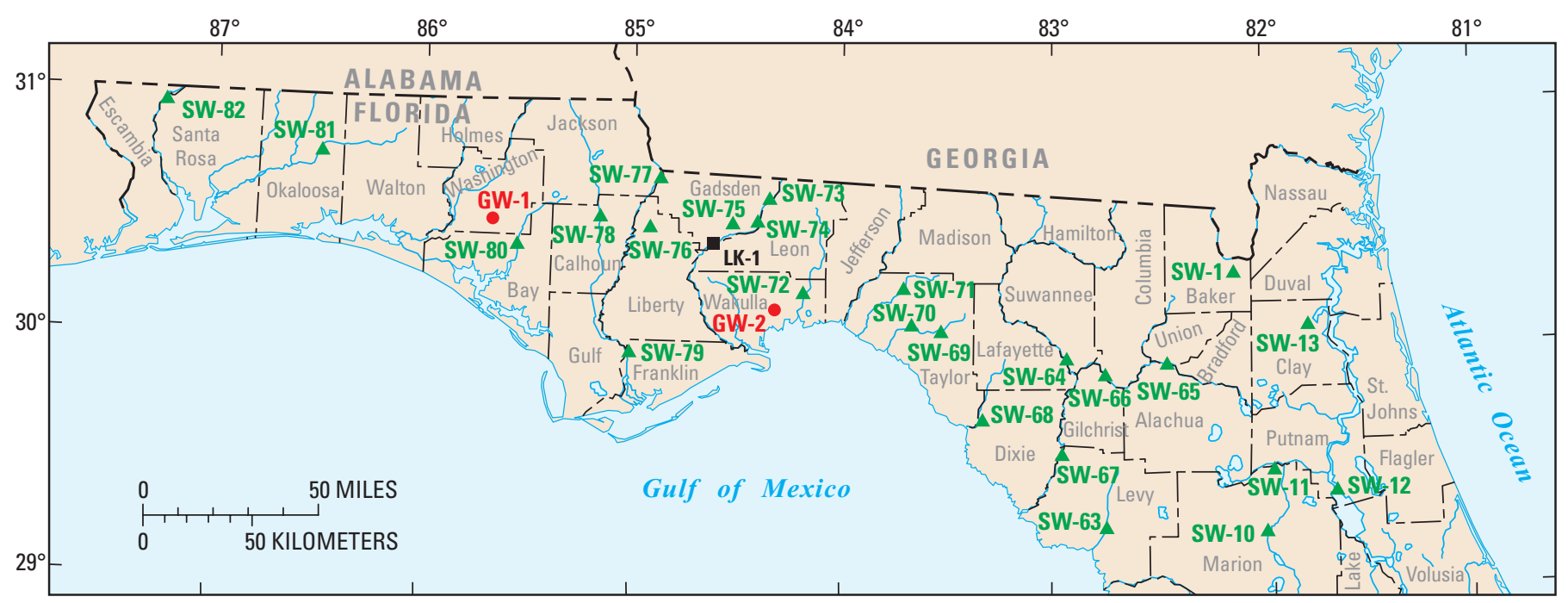

Base from U.S. Geological Survey digital data, 1:24,000, datum nad83 Albers Equal-Area Conic Projection,

Standard parallels $29^{\circ} 30^{\prime}$ and $45^{\circ} 30^{\prime}$, central meridian $-83^{\circ} 00^{\prime}$

Figure 2A. Locations of monitoring stations in northern Florida.

\section{EXPLANATION}

LOCATIONS OF SITES USED IN THIS REPORT

Numbers refer to table with site description

- LK-3 LAKE SITE - Location and number

A SW-3 SURFACE-WATER SITE - Location and number

- GW-3 GROUNDWATER SITE - Location and number

Figure 2B. Locations of monitoring stations in southern Florida.

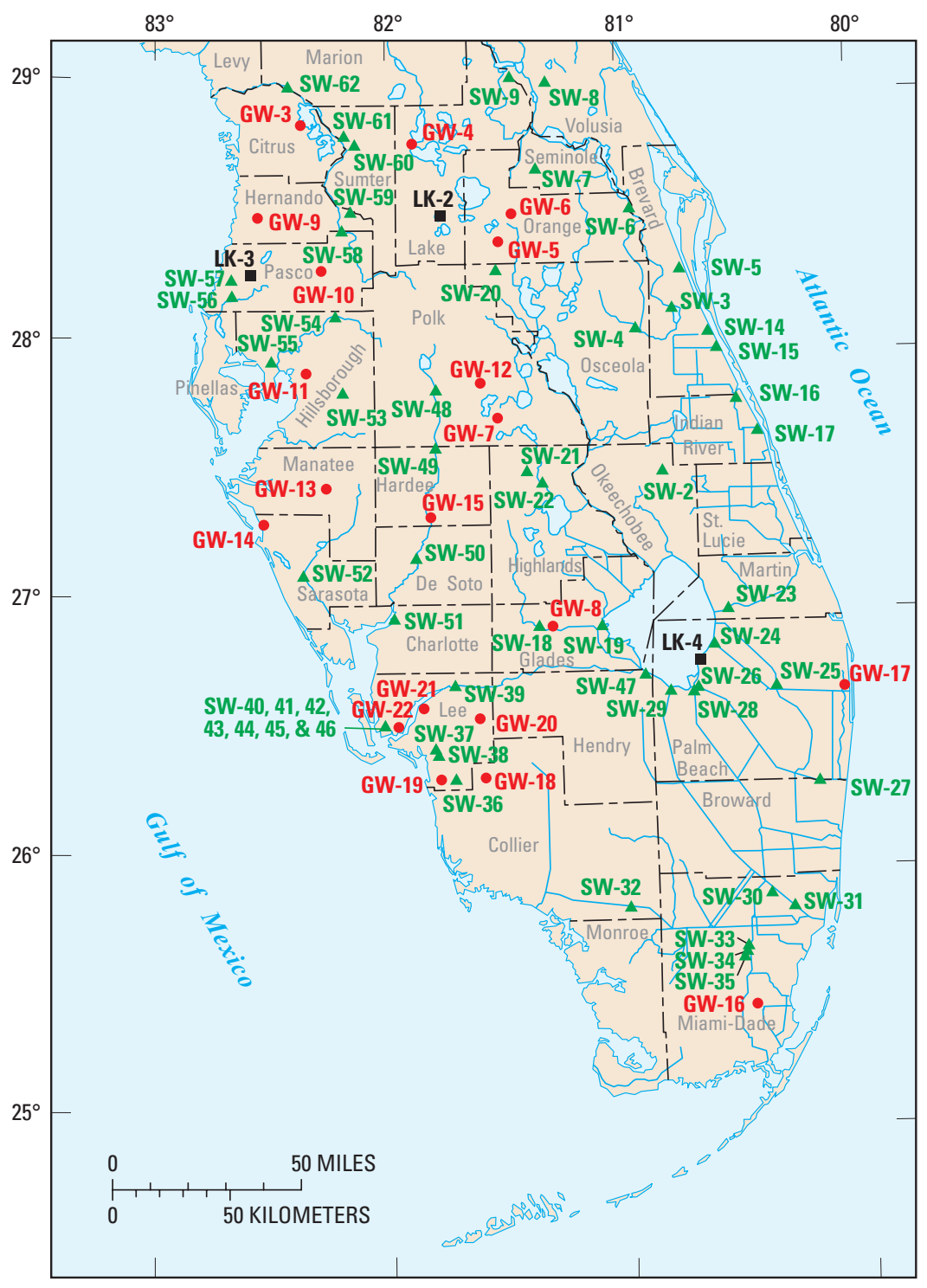

Base from U.S. Geological Survey digital data, 1:24,000, datum nad83 Albers Equal-Area Conic Projection,

Standard parallels $29^{\circ} 30^{\prime}$ and $45^{\circ} 30^{\prime}$, central meridian $-83^{\circ} 00^{\prime}$ 
Surface-Water Sites

SW-1 02231000 St. Mary's River near MacClenny, Baker County, FL

SW-2 02231342 Fort Drum Creek near Fort Drum, Okeechobee County, FL

SW-3 02232000 St. John's River near Melbourne, Brevard County, FL

SW-4 02232155 Pennywash Creek near Deer Park, Osceola County, FL

SW-5 02232400 St. John's River near Cocoa, Brevard County, FL

SW-6 02232500 St. John's River near Christmas, Orange County, FL

SW-7 02234384 Soldier Creek near Longwood, Seminole County, FL

SW-8 02236000 St. John's River near De Land, Lake County, FL

SW-9 02236125 St. John's River at Astor, Volusia County, FL

SW-10 02240000 Ocklawaha River near Conner, Marion County, FL

SW-11 02243000 Orange Creek at Orange Springs, Marion County, FL

SW-12 02243960 Ocklawaha River at Rodman Dam, near Orange Springs, Putnam County, FL

SW-13 02246025 Black Creek near Doctor's Inlet, Clay County, FL

SW-14 02249500 Crane Creek at Melbourne, Brevard County, FL

SW-15 02250030 Turkey Creek at Palm Bay, Brevard County, FL

SW-16 02251000 South Prong St. Sebastian River near Sebastian, Indian River County, FL

SW-17 02253000 Main Canal at Vero Beach, Indian River County, FL

SW-18 02256500 Fisheating Creek at Palmdale, Glades County, FL

SW-19 02257000 Fisheating Creek at Lakeport, Glades County, FL

SW-20 02266300 Reedy Creek near Vineland, Osceola County, FL

SW-21 02270000 Carter Creek near Sebring, Highlands County, FL

SW-22 02270500 Arbuckle Creek near De Soto City, Highlands County, FL

SW-23 02276877 St. Lucie Canal below S-308 near Port Mayaca, Martin County, FL

SW-24 02278000 West Palm Beach Canal at S-352 at Canal Point, Palm Beach County, FL

SW-25 02278500 Diversion to Conservation Area at S-5A near Loxahatchee, Palm Beach County, FL

SW-26 02280500 Hillsboro Canal below S-351 near South Bay, Palm Beach County, FL

SW-27 02281400 Hillsboro Canal near Margate, Broward County, FL

SW-28 02283500 North New River Canal below S-2 and S-351 near South Bay, Palm Beach County, FL

SW-29 02286400 Miami Canal at S-354 and S-3 at Lake Harbor, Palm Beach County, FL

SW-30 02287497 Northwest Wellfield Canal near Dade Broward Levee, Miami-Dade County, FL

SW-31 02288600 Miami Canal at Northwest 36th Street, Miami, Miami-Dade County, FL

SW-32 02288900 Tamiami Canal Outlets, 40-Mile Bend to Monroe, Collier County, FL

SW-33 02290766 Levee 31 North Extension at 4 Mile near West Miami, Miami-Dade County, FL

SW-34 02290767 Levee 31 North Extension at 5 Mile near West Miami, Miami-Dade County, FL

SW-35 02290768 Levee 31 North Extension at 7 Mile near West Miami, Miami-Dade County, FL

SW-36 02291524 Spring Creek Headwater near Bonita Springs, Lee County, FL

SW-37 02291580 North Branch Estero River at Estero, Lee County, FL

SW-38 02291597 South Branch Estero River at Estero, Lee County, FL

SW-39 02292900 Caloosahatchee River at S-79 near Olga, Lee County, FL

SW-40 02293214 Meade Canal at Cape Coral, Lee County, FL

SW-41 02293240 Aries Canal at Cape Coral, Lee County, FL

SW-42 02293241 San Carlos Canal at Cape Coral, Lee County, FL

SW-43 02293264 Gator Slough at State Road 765 at Cape Coral, Lee County, FL

SW-44 02293345 Shadroe Canal at Cape Coral, Lee County, FL

SW-45 02293346 Horseshoe Canal at Cape Coral, Lee County, FL

SW-46 02293347 Hermosa Canal at Cape Coral, Lee County, FL

SW-47 264514080550700 Industrial Canal at Clewiston, Hendry County, FL

SW-48 02294650 Peace River at Bartow, Polk County, FL

SW-49 02295420 Payne Creek near Bowling Green, Hardee County, FL

SW-50 02296750 Peace River at Arcadia, De Soto County, FL

SW-51 02298202 Shell Creek near Punta Gorda, Charlotte County, FL

SW-52 02298830 Myakka River near Sarasota, Sarasota County, FL

SW-53 02301500 Alafia River at Lithia, Hillsborough County, FL
SW-54 02303000 Hillsborough River near Zephyrhills, Hillsborough County, FL

SW-55 02306000 Sulphur Springs at Sulphur Springs, Hillsborough County, FL

SW-56 02310000 Anclote River near Elfers, Pasco County, FL

SW-57 02310300 Pithlachascotee River near New Port Richey, Pasco County, FL

SW-58 02312000 Withlacoochee River at Trilby, Hernando County, FL

SW-59 02312200 Little Withlacoochee River at Rerdell, Hernando County, FL

SW-60 02312700 Outlet River at Panacoochee Retreats, Sumter County, FL

SW-61 02312720 Withlacoochee River at Wysong Dam, at Carlson, Sumter County, FL

SW-62 02313000 Withlacoochee River near Holder, Marion County, FL

SW-63 02313700 Waccasassa River near Gulf Hammock, Levy County, FL

SW-64 02320500 Suwannee River at Branford, Suwannee County, FL

SW-65 02321500 Santa Fe River at Worthington Springs, Alachua County, FL

SW-66 02322500 Santa Fe River near Fort White, Gilchrist County, FL

SW-67 02323500 Suwannee River near Wilcox, Levy County, FL

SW-68 02324000 Steinhatchee River near Cross City, Taylor County, FL

SW-69 02324400 Fenholloway River near Foley, Taylor County, FL

SW-70 02325000 Fenholloway River near Perry, Taylor County, FL

SW-71 02326000 Econfina River near Perry, Taylor County, FL

SW-72 02326900 St. Marks River near Newport, Wakulla County, FL

SW-73 02328522 Ochlockonee River near Concord, Leon County, FL

SW-74 $02329000 \quad$ Ochlockonee River near Havana, Leon County, FL

SW-75 02329600 Little River near Midway, Gadsden County, FL

SW-76 02330100 Telogia Creek near Bristol, Liberty County, FL

SW-77 02358000 Apalachicola River at Chatthoochee, Gadsden County, FL

SW-78 02359000 Chipola River near Altha, Calhoun County, FL

SW-79 02359170 Apalachicola River near Sumatra, Franklin County, FL

SW-80 02359500 Econfina Creek near Bennett, Bay County, FL

SW-81 02369000 Shoal River near Crestview, Okaloosa County, FL

SW-82 02375500 Escambia River near Century, Santa Rosa County, FL

Groundwater Sites

GW-1 303025085350501 Well 422A near Greenhead, Washington County, FL

GW-2 300740084293001 Benchmark Well near Crawfordville, Wakulla County, FL

GW-3 285102082204001 DOT-41 at Inverness, Citrus County, FL

GW-4 284842081533001 College Street Well at Leesburg, Lake County, FL

GW-5 282202081384601 Lake Oliver Deep well near Vineland, Orange County, FL

GW-6 $283253081283401 \quad$ OR-47 at Orlo Vista, Orange County, FL

GW-7 $274812081190301 \quad$ P-49 near Frostproof, Polk County, FL

GW-8 270157081203101 H-15A near Palmdale, Highlands County, FL

GW-9 283201082315601 Weeki Wachee Well near Weeki Wachee, Hernando County, FL

GW-10 281715082164401 HWY 577 Well near San Antonio, Pasco County, FL

GW-11 275627082150801 Turner Well near Brandon, Hillsborough County, FL

GW-12 275411081372001 ROMP 57 Well near Lake Wales, Polk County, FL

GW-13 272838082142201 Kibler Deep Well 26B near Bethany, Manatee County, FL

GW-14 271938082251801 Sarasota Well 9 near Sarasota, Sarasota County, FL

GW-15 272012081482501 Marshall Deep Well near Gardner,

De Soto County, FL

GW-16 253029080295601 S-196A near Homestead, Miami-Dade County, FL

GW-17 263524080124301 PB-683 near West Palm Beach,

Palm Beach County, FL

GW-18 260111081243901 C-496 at Corkscrew Sanctuary, Collier County, FL

GW-19 261957081432201 L-2194 near Bonita Springs, Lee County, FL

GW-20 $263335081394301 \quad$ L-729 near Lehigh Acres, Lee County, FL

GW-21 263251081452801 L-1993 near Fort Myers, Lee County, FL

GW-22 263526082010201 L-2434 near Cape Coral, Lee County, FL

\section{Lake Sites}

LK-1 02329900 Lake Talquin near Bloxham, Leon County, FL

LK-2 02236840 Lake Minnehaha at Clermont, Lake County, FL

LK-3 02310290 Moon Lake in Pasco County, FL

LK-4 02276400 Lake Okeechobee, Palm Beach County, FL

Figure 2. Location of monitoring stations in Florida.-Continued. 
interstate and international waters, flood forecasts, large riverbasin outflows, sentinel watersheds, and water quality. The USGS Cooperative Water Program funds the majority of the data-collection stations in Florida through cost-sharing agreements with water management districts, several State agencies, and many local county and municipal governments.

During the 2008 water year, these programs funded 450 continuous discharge stations, 235 stage-only stations, 405 continuous groundwater stations, 1,200 periodic groundwater stations, 145 continuous water-quality stations, and waterquality samples at 190 discharge and 200 groundwater stations. About 75 percent of the continuous record stations have real-

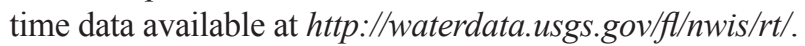

Cooperative agreements between the USGS and Florida agencies for the collection of water-resources records have existed since 1930. Agencies that had cooperative agreements with the USGS during the 2008 water year are listed below. Funding for water-resources monitoring through the Jacksonville and Mobile Districts, U.S. Army Corp of Engineers, was obtained through a Military Interdepartmental Purchase Request.

\author{
Big Cypress Park \\ City of Bradenton \\ City of Cocoa Utilities \\ City of North Port \\ City of Sanibel \\ City of Sarasota \\ City of Tallahassee \\ City of Tampa \\ County of Broward \\ County of Hillsborough \\ County of Lee \\ County of Manatee \\ County of Miami-Dade \\ County of Okaloosa \\ County of Pinellas \\ County of Santa Rosa \\ County of Sarasota \\ County of Seminole \\ County of Walton \\ Florida Department of Environmental Protection \\ Florida Department of Transportation \\ Jacksonville Electric Authority \\ Lake County Water Authority \\ Miami-Dade Water and Sewer \\ Northwest Florida Water Management District \\ Orange County Environmental Protection Division \\ Peace River Regional Water Supply Authority \\ Reedy Creek Improvement District \\ Seminole Tribe \\ South Florida Water Management District \\ Southwest Florida Water Management District \\ St. Johns Water Management District \\ Suwannee River Water Management District \\ Tampa Bay Water
}

\section{Hydrologic Conditions in Florida}

This section describes the hydrologic conditions in Florida during the 2008 water year. Analyses of data are made for precipitation, surface-water flows, lake elevations, and groundwater levels.

\section{Precipitation}

Precipitation quantity and timing affect the hydrologic conditions in streams, lakes, and aquifers in Florida. Although the USGS collects some meteorological data (primarily for project or operational needs), the National Oceanic and Atmospheric Administration, National Weather Service, combines this information with data collected by many other organizations and provides detailed summaries, including weekly and monthly maps depicting: (1) monthly observed precipitation, (2) monthly percentage of normal precipitation, and (3) the weekly drought monitor. Examples of these maps are provided in figures 3 to 5 . For this report, the term precipitation refers to rainfall. These summaries of rainfall and drought data were used to provide the narrative of rainfall conditions for the 2008 water year, and to serve as background information for understanding changes in water levels and flow in Florida's streams, lakes, and aquifers. In this section, long-term average is defined as an average total rainfall for Florida from 1907 to 2007. Statewide average daily rainfall is defined as the average of all recorded precipitation values across the state for the given date.

The drought-intensity categories used in the text and figure 5 reflect input from several indicators with different scales of units. The indices used are Percent of Normal Precipitation, Standardized Precipitation Index, Palmer Drought Severity Index, Crop Moisture Index, Surface Water Supply Index, and the Reclamation Drought Index (Hayes, 2008). Generally, these indicators reflect a system of ranking percentiles to correlate with the different intensities (Fuchs, National Drought Mitigation Center, written commun. 2008). Abnormally dry reflects indices that mostly fall within the lowest 30 percent. Moderate drought reflects indices mostly in the lowest 20 percent. Severe drought reflects indices mostly in the lowest 10 percent. Extreme drought reflects indices mostly in the lowest 5 percent. Exceptional drought reflects indices mostly in the lowest $1-2$ percent.

October 2007-Precipitation in Florida was slightly higher than normal during October. The long-term average for Florida in October is 3.83 in. (inches); the average for October in 2007 was greater than $5.50 \mathrm{in}$. The statewide average precipitation was 2.06 in. on October 24, thus setting a new daily record (http://www.sercc.com/climateinfo_files/monthly/Florida_prcp. $h t m l)$. The highest monthly total precipitation during October was 17.44 in., recorded at the Pensacola Regional Airport. 


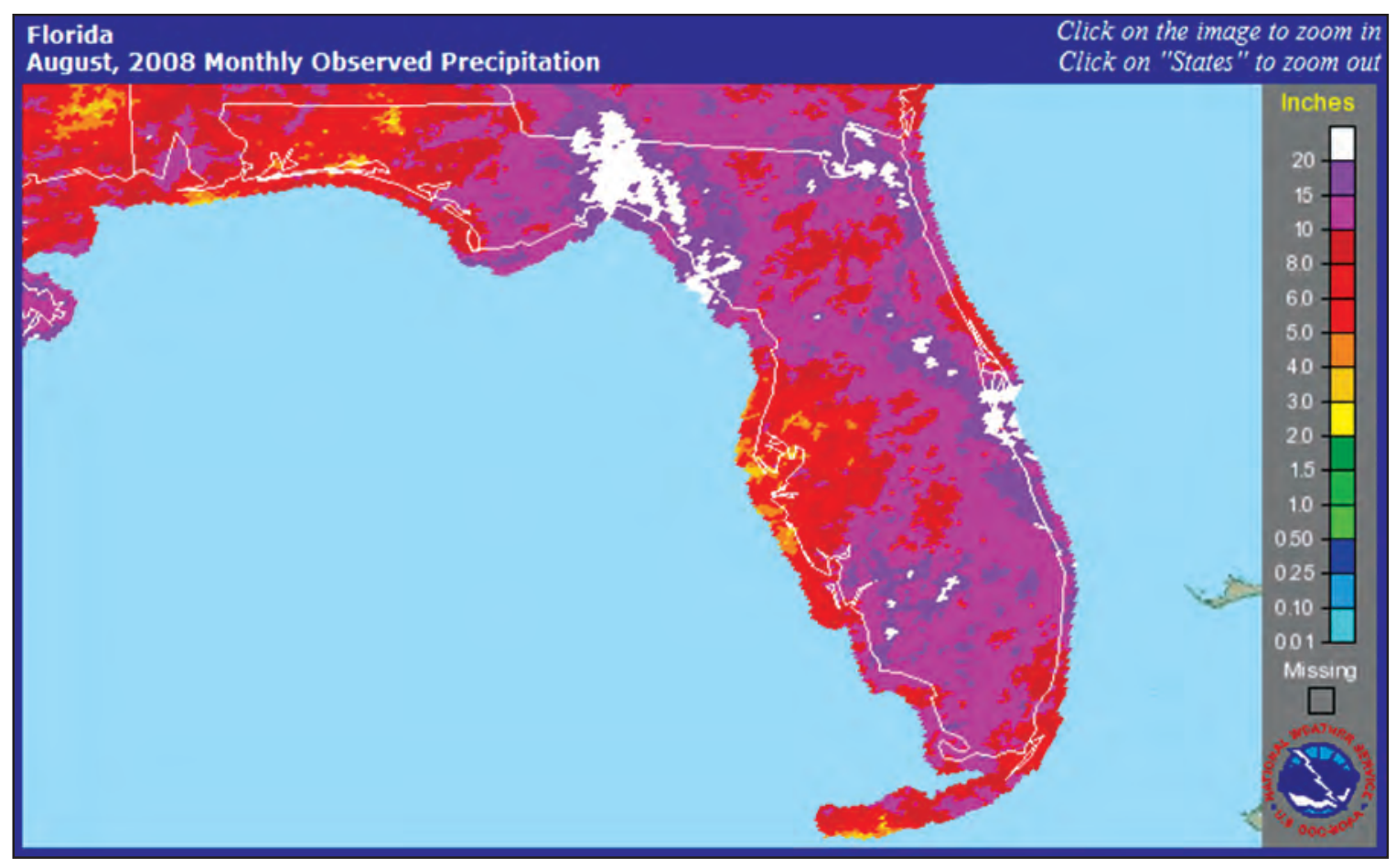

Figure 3. Example of the monthly observed precipitation maps provided by the National Oceanic and Atmospheric Administration, National Weather Service, August 2008.

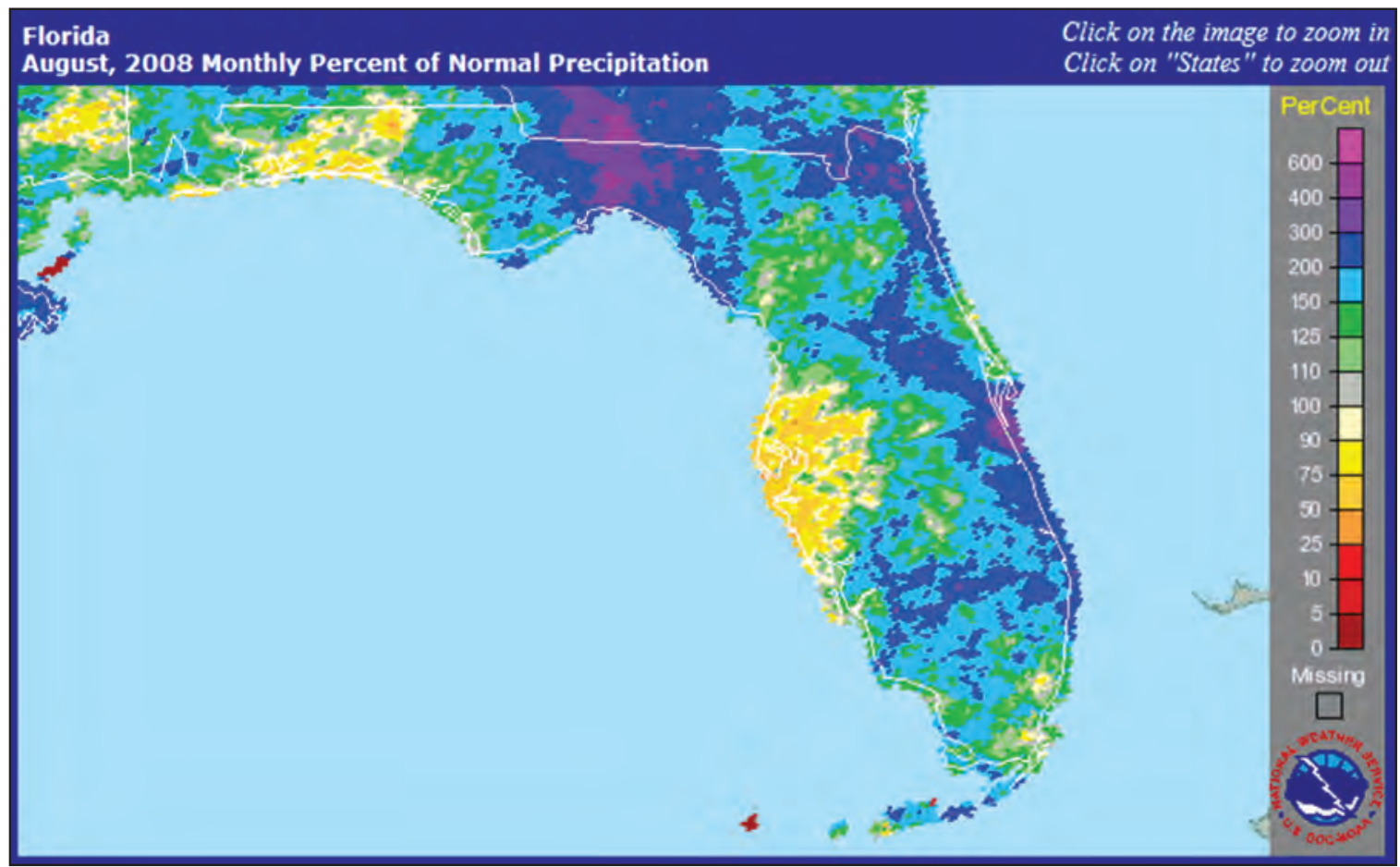

Figure 4. Example of the monthly percentage of normal precipitation maps provided by the National Oceanic and Atmospheric Administration, National Weather Service, August 2008. 
A

\section{U.S. Drought Monitor January 29, 2008} Florida

\begin{tabular}{|c|c|c|c|c|c|c|}
\hline & \multicolumn{6}{|c|}{ Drought Conditions (Percent Area) } \\
\hline & None & DO-D4 & D1-D4 & D2-D4 & D3-D4 & D4 \\
\hline Current & 15.9 & 84.1 & 29.0 & 19.4 & 3,0 & 0.0 \\
\hline $\begin{array}{l}\text { Last Week } \\
\text { 101/222/2008 mapl }\end{array}$ & 11.1 & 88.9 & 34.5 & 19.4 & 2.6 & 0.0 \\
\hline $\begin{array}{l}3 \text { Months Ago } \\
\text { (11106/2007 map) }\end{array}$ & 45,3 & 54,7 & 17,4 & $4 . \overline{6}$ & 0,0 & 0.0 \\
\hline $\begin{array}{l}\text { Start of } \\
\text { Calendar Year } \\
\text { (01/101/2008 map) }\end{array}$ & 31.8 & 68.2 & 33.1 & 19.7 & 2.6 & 0,0 \\
\hline $\begin{array}{c}\text { Start of } \\
\text { Water Year } \\
\text { (100022007 map) }\end{array}$ & 20,8 & 79,2 & 44.2 & 22.0 & 9,1 & 0.0 \\
\hline $\begin{array}{c}\text { One Year Ago } \\
\text { (01/30/2007 map) }\end{array}$ & 19.4 & 80.6 & 53.3 & 16.0 & 0.0 & 0.0 \\
\hline \multicolumn{7}{|c|}{ Intensity: } \\
\hline \multicolumn{3}{|c|}{ Do Abnormally Dry } & \multicolumn{4}{|c|}{ D3 Drought - Extreme } \\
\hline \multicolumn{3}{|c|}{ D1 Drought-Moderate } & \multicolumn{4}{|c|}{ D4 Drought - Exceptional } \\
\hline \multicolumn{3}{|c|}{ D2 Drought - Severe } & & & & \\
\hline
\end{tabular}

The Drought Monitor focuses on broad-scale conditions. Local conditions may vary. See accompanying text summary for forecast statements.

http://drought.unl.edu/dm
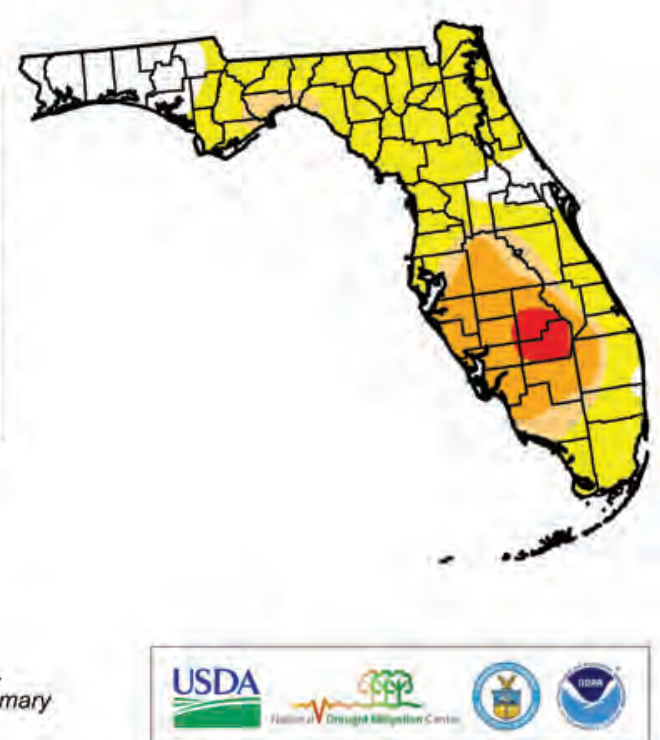

Released Thursday, January 31, 2008 Author: David Miskus, JAWF/CPC/NOAA

$\boldsymbol{B}$

\section{U.S. Drought Monitor July 29,2008 Florida}

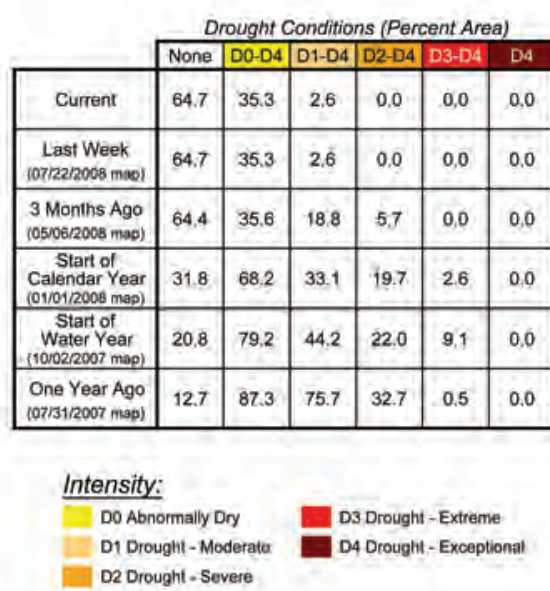

The Drought Monitor focuses on broad-scale conditions. Local conditions may vary. See accompanying text summary for forecast statements.

http://drought.unl.edu/dm
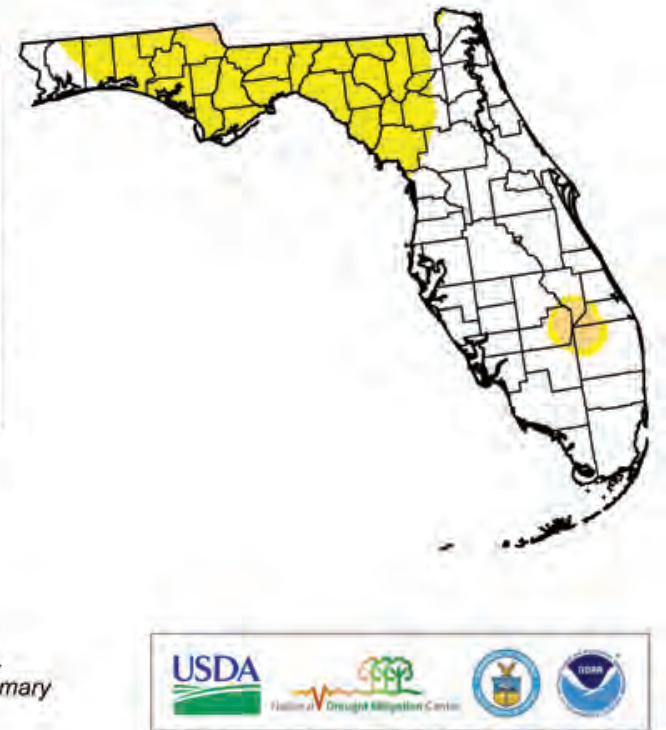

Released Thursday, July 31, 2008 Author: B. Fuchs, NDMC, and L. Edwards, WRCC

Figure 5. Example of the weekly drought monitor maps provided by the National Oceanic and Atmospheric Administration, National Weather Service, A, January 2008, and B, July 2008. 
November 2007-Northwest Florida received below normal rainfall amounts during November. The south-central area, the southwest coast, and the Everglades received less than 1.0 in. of precipitation, on average. Ft. Myers, Bonita Springs, and surrounding areas were in moderate drought conditions. New Hope received the highest monthly total of 7.26 in. of precipitation. The statewide average precipitation was 1.37 in. for November, nearly $1 \mathrm{in}$. below the long-term average of $2.33 \mathrm{in}$.

December 2007-Statewide precipitation was below normal during December. Niceville had the highest amount of monthly total precipitation, with 9.09 in. On December 16, a cold front that stalled across the Gulf of Mexico brought significant rainfall to the northwest, north, and north-central parts of Florida. During this event, New Hope received 3.45 in., Cross City received 2.80 in., and De Land received 2.30 in. of precipitation. Although north Florida received near-normal amounts of rainfall in December, south Florida was unusually dry, causing severe drought conditions in south-central Florida.

January 2008 — January rainfall was below normal throughout the State, continuing the drought conditions for most of Florida. Abnormally dry conditions extended from the panhandle into central Florida. Moderate to extreme drought conditions existed in southwest Florida. Big Cypress, the Everglades, Marco Island, and Naples Municipal Airport all received less than 1 in. of precipitation during January.

February 2008 - Northwest and north Florida had two significant rainfall events that resulted in above normal average totals on February 17-18 and February 21-23. Panama City received 14.37 in., Clarksville received 11.68 in., and Marianna received 10.33 in. for February. Although the heavy rainfall alleviated the abnormally dry conditions across the panhandle, extreme drought conditions continued in southcentral Florida. Most of this region received less than the long-term average of 3.19 in. for February. Arcadia, Avon Park, Bradenton, Ft. Pierce, Myakka River State Park, Parrish, Venice, and Vero Beach were a few of the locations that received less than 2 in. of precipitation for February.

March 2008-Statewide precipitation was below normal for March. South-central Florida and the lower east coast of Florida received on average $3.5 \mathrm{in}$. and $4.9 \mathrm{in}$., respectively. The D3-Extreme drought condition west of Lake Okeechobee improved to D1-Moderate drought condition. Stuart received the highest total amount of rainfall in the State (8.54 in.) during March.

April 2008-Rainfall was above normal in Florida as widespread rainfall events temporarily relieved most drought conditions. Naples received 7.50 in., Saint Leo 6.14 in., Plant City 5.49 in., and Tallahassee 4.02 in. However, D0-D1 drought conditions persisted along the southwest coast of Florida from Bradenton to the Everglades.
May 2008-Heavy rainfall during May in southeast Florida produced 2 to 6 in. of precipitation in some areas. However, statewide precipitation totals were still 2.18 in. below normal. Miami Beach received the highest total precipitation (6.05 in.), nearly doubling the long-term statewide average for May. The southeast coast of Florida was in normal to D0 abnormally dry conditions. D0-D2 drought conditions continued in southwest Florida. Normal to D0 conditions existed north of Rusk. Two stations in the Florida Keys, Islamorada and the Dry Tortugas, as the Kissimmee station recorded no precipitation for May.

June 2008-The southeast coast of Florida continued to receive above normal rainfall in June. Miami received more than 7 in. Despite the abundant rainfall in Miami and throughout the State, groundwater levels remained lower than normal. During June, most of Florida was at minimum D0 drought conditions. The precipitation in south Florida alleviated the D1 and D2 drought conditions.

July 2008-Precipitation for Florida was 0.83 in. above normal for July. Big Corkscrew received the highest total precipitation with $17.96 \mathrm{in}$. The highest 24-hour total precipitation occurred on July 17 at March Island, which received 6.13 in. Northwest Florida was below normal for July. Tallahassee was 3.77 in. below the long-term average. D0 drought conditions existed in northwest Florida and areas surrounding Lake Okeechobee. Most of Florida received abundant rainfall during July, thus alleviating the previous D0-D2 drought conditions.

August 2008 - Due to the large amount of precipitation produced by Tropical Storm Fay, drought conditions were nonexistant in Florida during August. Due to the slow movement of this tropical system, precipitation exceeded 24 in. across parts of east-central Florida. Big Corkscrew station received the highest total precipitation for the second consecutive month with 32.35 in. of rainfall. Precipitation for Melbourne was $27.65 \mathrm{in}$. and the panhandle received $10 \mathrm{in.} \mathrm{or}$ more, on average.

September 2008 - After the record-setting totals produced by Tropical Storm Fay during August, precipitation throughout Florida during September was much lower than normal. D0 drought conditions (fig. 5A) returned to the western part of the panhandle. Tampa Bay area had minimal effects from the Tropical Fay rainfall during August. St. Petersburg received only 1.20 in. of precipitation during September, thus causing a -6.39 in. departure from normal. The entire south-central region of the State was at least $24 \mathrm{in}$. below normal. Overall, water year 2008 concluded with near normal conditions throughout Florida. 


\section{Surface Water}

Annual discharge rates varied across Florida during the 2008 water year and ranged from below normal across the State to near normal in parts of the panhandle. Several sites reached record-low monthly mean discharges during the year, while others reached record-high monthly mean discharges. Record-low discharges throughout the State were the result of below normal rainfall and runoff associated with drought conditions continuing from the 2007 water year. Record-high monthly mean discharges and instantaneous peak river elevations and/or discharges that occur in August and September were the direct result of heavy rainfall associated with the four Florida landfalls of Tropical Storm Fay beginning August 18 (Verdi and Holt, 2010).

Table 1 provides data from 29 representative streamgages across the State of Florida showing water years 2007 (as a comparison) and 2008 annual mean discharge and percent of mean for the period of record. Table 2 provides data showing record-low monthly mean discharges, month(s) of occurrence, and previous record and year of occurrence for streamgages across the State. Table 3 provides data showing record-high monthly mean discharges, month(s) of occurrence, and previous record and year of occurrence for streamgages across the State. Table 4 provides the peak discharge and gage height for sites reaching period of record instantaneous peak discharges caused by Tropical Storm Fay.

Discharge hydrographs for the representative streams in Florida are shown in figures 6 to 34. The upper graph $A$ shows the 2008 water year monthly mean discharge compared to the maximum, minimum, and mean monthly mean discharge for the period of record at that site. The lower graph $B$ shows the monthly mean discharge for the 1999-2008 calendar years.

\section{Northwest Florida}

Annual mean discharge across northwest Florida was below normal to near normal during the 2008 water year, but was below normal during the previous year (table 1). For example, the annual discharge at Suwannee River at Branford (02320500) during water year 2008 was $4,270 \mathrm{ft}^{3} / \mathrm{s}$, which is 62 percent of the period of record (1931-2008) average of $6,840 \mathrm{ft}^{3} / \mathrm{s}$ (table 1). The annual discharge at Santa Fe River at Worthington Springs (02321500) was $224 \mathrm{ft}^{3} / \mathrm{s}$, which is 54 percent of the period of record (1932-2008) average of $411 \mathrm{ft}^{3} / \mathrm{s}$. This is a significant increase from the previous year when annual discharge was less than 1 percent of the period of record average (table 1). The annual discharge at Shoal River near Crestview (02369000) was $1,010 \mathrm{ft}^{3} / \mathrm{s}$ during the 2008 water year, which is 92 percent of the period of record (1938-2008) average of $1,100 \mathrm{ft}^{3} / \mathrm{s}$ (table 1).

Monthly mean discharges averaged well below normal from October through July, but then averaged near normal to above normal during August and September. Streamgages throughout northwest Florida reached record-low or recordhigh monthly mean discharges during the year (tables 2 and 3 ). Some streamgage locations recorded peak of record discharge associated with the rainfall and runoff from Tropical Storm Fay (table 4). Figures 6 through 12 show the seven representative streams in northwest Florida.

The dry conditions throughout the analysis period from October to July were caused by less than normal rainfall that had persisted throughout the region. Several streamgage locations registered record-low monthly mean discharges during the year (table 2). For example, monthly mean discharges reached period of record (1928-1930 and 1932-2008) low levels during October $\left(727 \mathrm{ft}^{3} / \mathrm{s}\right)$ and November $\left(620 \mathrm{ft}^{3} / \mathrm{s}\right)$ at Santa Fe River near Fort White (02322500). The previous records were in $1956\left(730 \mathrm{ft}^{3} / \mathrm{s}\right)$ and $2002\left(636 \mathrm{ft}^{3} / \mathrm{s}\right)$, respectively (table 2). Econfina Creek near Bennett (02359500) reached period-of-record (1936-1994 and 1999-2008) low monthly mean discharges during November $\left(312 \mathrm{ft}^{3} / \mathrm{s}\right)$. The previous record was $323 \mathrm{ft}^{3} / \mathrm{s}$ in 1956 (table 2).

Higher than normal monthly mean discharges during August and September were the direct result of Tropical Storm Fay moving through this part of Florida from August 22 to 24 (Verdi and Holt, 2010). A few streamgages in northwest Florida reached record-high monthly mean discharges during August or September. For example, the St. Marks River near Newport (02326900; period of record from 1957-1976; 1992-1994, and 1996-2008) gage reached a new September high monthly mean discharge of $1,660 \mathrm{ft}^{3} / \mathrm{s}$. The previous record was 1,560 ft $\mathrm{ft}^{3} / \mathrm{s}$, set in 1957 (table 3). The Little River near Midway (02329600; period of record from 1986-2008) gage reached a new August high monthly mean discharge of $1,740 \mathrm{ft}^{3} / \mathrm{s}$. The previous record there was $1,620 \mathrm{ft}^{3} / \mathrm{s}$ set in 1994 (table 3).

Instantaneous peak discharge and other notable discharge peaks associated with Tropical Storm Fay occurred during 2008. For example, the St. Mark's River near Newport streamgage (02326900; period of record from 1957-1976; 1992-1994, and 1996-2008) recorded a peak discharge of $5,890 \mathrm{ft}^{3} / \mathrm{s}$ on August 25 (table 4). A discharge event of this magnitude has an exceedance probability of less than 0.01 , indicating the event has less than a 1 percent chance of occurring in any given year (table 4) (Verdi and Holt, 2010). The Ochlockonee River near Concord streamgage (02328522; period of record from 1999 to 2008) recorded a peak discharge of $54,400 \mathrm{ft}^{3} / \mathrm{s}$ on August 25 (table 4). The Ochlockonee River near Havana streamgage (02329000) recorded a peak discharge of $37,400 \mathrm{ft}^{3} / \mathrm{s}$ on August 25, which is the second highest recorded peak in its 83-year period of record from 1926 to 2008. A discharge event of this magnitude has an exceedance probability of 0.01 to 0.02 , indicating the event size has a 1 to 2 percent chance of occurring in any given year. The record peak of 55,900 ft $3 / \mathrm{s}$ at the Havana gage occurred during the flood of April 4, 1948 (Verdi and Holt, 2010). 
Table 1. Relation of period-of-record mean annual discharge to mean discharge for the 2007 and 2008 water years.

[Discharge values listed in cubic feet per second]

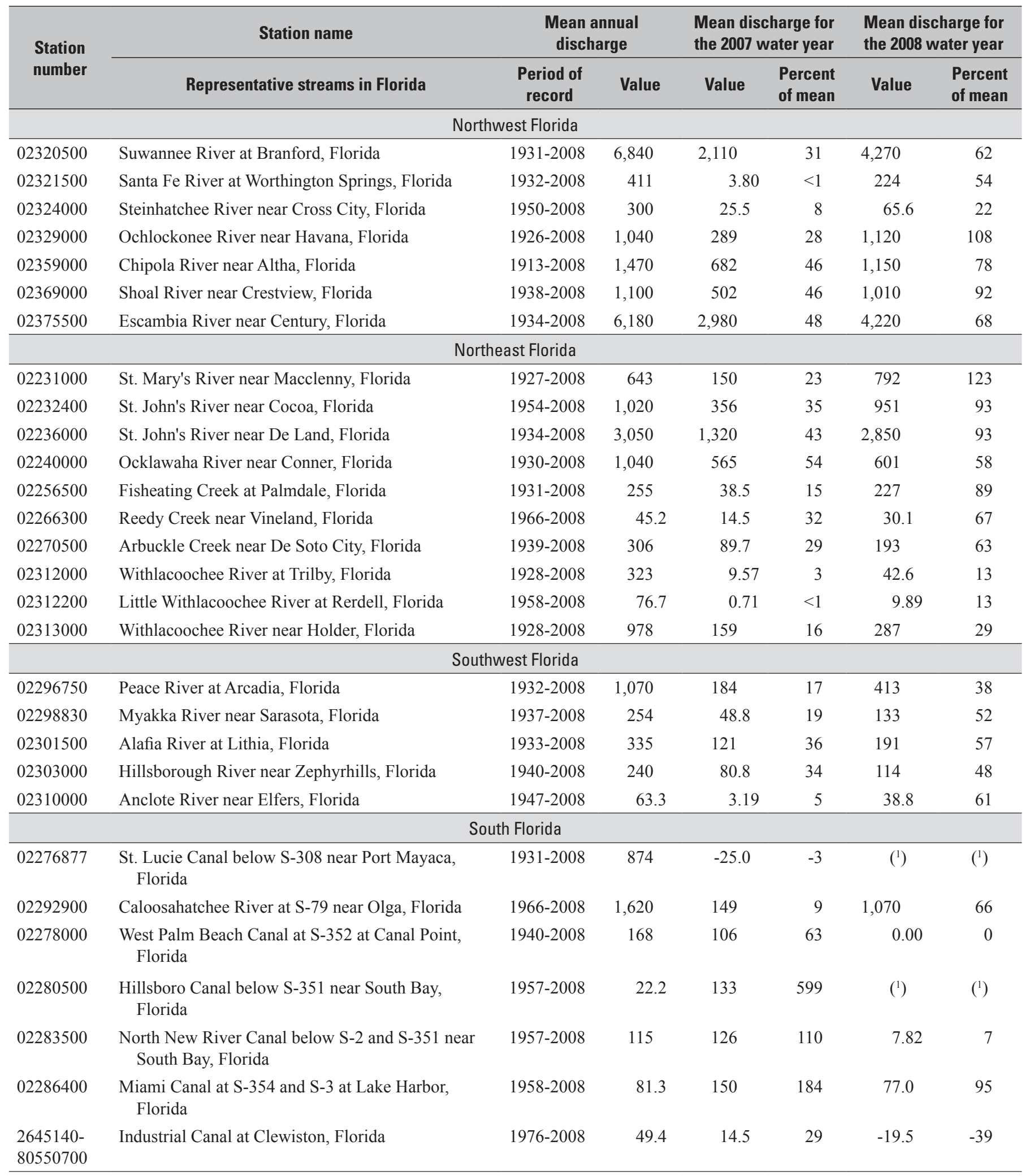

${ }^{1}$ Insufficient data available to compute an annual mean discharge. 
Table 2. Stations reaching record-low monthly mean discharge and month(s) of occurrence during the 2008 water year and their previous record and year of occurrence.

[Discharge values listed in cubic feet per second]

\begin{tabular}{|c|c|c|c|c|c|c|}
\hline $\begin{array}{l}\text { Station } \\
\text { number }\end{array}$ & Station name & $\begin{array}{l}\text { Period of } \\
\text { record }\end{array}$ & $\begin{array}{c}\text { Month of } \\
\text { record-low } \\
\text { discharge in } \\
2008\end{array}$ & Discharge & $\begin{array}{l}\text { Previous } \\
\text { record } \\
\text { discharge }\end{array}$ & $\begin{array}{c}\text { Year of } \\
\text { occurrence }\end{array}$ \\
\hline \multicolumn{7}{|c|}{ Northwest Florida } \\
\hline 02313700 & $\begin{array}{l}\text { Waccasassa River near Gulf } \\
\text { Hammock, Florida }\end{array}$ & $\begin{array}{l}\text { 1963-1978;1981-1984; } \\
\text { 1985-1992; 1999-2008 }\end{array}$ & August & 20.5 & 29.1 & 1991 \\
\hline 02322500 & Santa Fe River near Fort White, Florida & $1928-1930 ; 1932-2008$ & $\begin{array}{l}\text { October } \\
\text { November }\end{array}$ & $\begin{array}{l}727 \\
620\end{array}$ & $\begin{array}{l}730 \\
636\end{array}$ & $\begin{array}{l}1956 \\
2002\end{array}$ \\
\hline 02323500 & Suwannee River near Wilcox, Florida & $1931 ; 1942-2008$ & $\begin{array}{l}\text { October } \\
\text { November } \\
\text { December }\end{array}$ & $\begin{array}{l}2,480 \\
2,110 \\
1,880\end{array}$ & $\begin{array}{l}3,010 \\
3,210 \\
2,580\end{array}$ & $\begin{array}{l}2003 \\
2002 \\
2002\end{array}$ \\
\hline 02324400 & Fenholloway River near Foley, Florida & $1956-2008$ & $\begin{array}{l}\text { November } \\
\text { December } \\
\text { June } \\
\text { July }\end{array}$ & $\begin{array}{l}0.55 \\
0.55 \\
0.31 \\
0.33\end{array}$ & $\begin{array}{l}0.70 \\
0.58 \\
0.32 \\
0.36\end{array}$ & $\begin{array}{l}1969 \\
2001 \\
2000 \\
2000\end{array}$ \\
\hline 02325000 & Fenholloway River near Perry, Florida & $\begin{array}{l}\text { 1952-1954; 1965-1984; } \\
\text { 1986-2008 }\end{array}$ & $\begin{array}{l}\text { October } \\
\text { May } \\
\text { June } \\
\text { July }\end{array}$ & $\begin{array}{l}72.1 \\
75.5 \\
74.1 \\
71.0\end{array}$ & $\begin{array}{l}75.3 \\
77.1 \\
76.1 \\
75.9\end{array}$ & $\begin{array}{l}2002 \\
2001 \\
2001 \\
2004\end{array}$ \\
\hline 02326000 & Econfina River near Perry, Florida & $1950-2008$ & $\begin{array}{l}\text { October } \\
\text { November } \\
\text { December } \\
\text { January } \\
\text { June } \\
\text { July }\end{array}$ & $\begin{array}{l}0.81 \\
0.04 \\
0.00 \\
0.13 \\
3.80 \\
2.39\end{array}$ & $\begin{array}{l}6.26 \\
8.18 \\
6.22 \\
9.47 \\
4.80 \\
4.49\end{array}$ & $\begin{array}{l}1994 \\
1969 \\
1991 \\
1957 \\
1955 \\
1955\end{array}$ \\
\hline 02359000 & Chipola River near Altha, Florida & $1913-2008$ & November & 309 & 370 & 1991 \\
\hline 02359170 & $\begin{array}{l}\text { Apalachicola River near Sumatra, } \\
\text { Florida }\end{array}$ & $1978-2008$ & $\begin{array}{l}\text { November } \\
\text { December } \\
\text { June }\end{array}$ & $\begin{array}{l}5,860 \\
6,520 \\
5,790\end{array}$ & $\begin{array}{l}6,480 \\
7,970 \\
6,080\end{array}$ & $\begin{array}{l}2002 \\
2002 \\
2000\end{array}$ \\
\hline 02359500 & Econfina Creek near Bennett, Florida & $1936-1994 ; 1999-2008$ & November & 312 & 323 & 1956 \\
\hline \multicolumn{7}{|c|}{ Northeast Florida } \\
\hline 02232000 & $\begin{array}{l}\text { St. John's River near Melbourne, } \\
\text { Florida }\end{array}$ & $1940-2008$ & $\begin{array}{l}\text { April } \\
\text { May }\end{array}$ & $\begin{array}{l}-22.3 \\
-46.0\end{array}$ & $\begin{array}{l}0.00 \\
-23.5\end{array}$ & $\begin{array}{l}1956 \\
2000\end{array}$ \\
\hline 02232155 & $\begin{array}{l}\text { Pennywash Creek near Deer Park, } \\
\text { Florida }\end{array}$ & $1995-2008$ & May & 0.02 & 0.10 & 2007 \\
\hline 02232500 & St. John's River near Christmas, Florida & $1934-2008$ & June & 5.43 & 8.45 & 2000 \\
\hline 02236125 & St. John's River at Astor, Florida & 1994-2008 & December & 954 & 1,140 & 2001 \\
\hline
\end{tabular}




\section{Hydrologic Conditions in Florida during Water Year 2008}

Table 2. Stations reaching record-low monthly mean discharge and month(s) of occurrence during the 2008 water year and their previous record and year of occurrence.-Continued

[Discharge values listed in cubic feet per second]

\begin{tabular}{|c|c|c|c|c|c|c|}
\hline $\begin{array}{l}\text { Station } \\
\text { number }\end{array}$ & Station name & $\begin{array}{l}\text { Period of } \\
\text { record }\end{array}$ & $\begin{array}{l}\text { Month of } \\
\text { record-low } \\
\text { discharge in } \\
2008\end{array}$ & Discharge & $\begin{array}{l}\text { Previous } \\
\text { record } \\
\text { discharge }\end{array}$ & $\begin{array}{c}\text { Year of } \\
\text { occurrence }\end{array}$ \\
\hline \multicolumn{7}{|c|}{ Northeast Florida-Continued } \\
\hline 02243000 & $\begin{array}{l}\text { Orange Creek at Orange Springs, } \\
\text { Florida }\end{array}$ & $\begin{array}{l}\text { 1942-1951; 1956-1971; } \\
\text { 1975-2008 }\end{array}$ & June & 2.16 & 2.31 & 2000 \\
\hline 02246025 & Black Creek near Doctor's Inlet, Florida & $\begin{array}{l}\text { 1982-1987; 1995-1997; } \\
\text { 2001-2008 }\end{array}$ & $\begin{array}{l}\text { November } \\
\text { December } \\
\text { May } \\
\text { June }\end{array}$ & $\begin{array}{l}115 \\
99.2 \\
27.6 \\
72.2\end{array}$ & $\begin{array}{c}131 \\
104 \\
96.8 \\
127\end{array}$ & $\begin{array}{l}2007 \\
1983 \\
1982 \\
1984\end{array}$ \\
\hline 02251000 & $\begin{array}{l}\text { South Prong St. Sebastian River near } \\
\text { Sebastian, Florida }\end{array}$ & 1994-2008 & $\begin{array}{l}\text { January } \\
\text { February } \\
\text { May } \\
\text { June }\end{array}$ & $\begin{array}{c}28.6 \\
25.2 \\
9.04 \\
7.49\end{array}$ & $\begin{array}{l}33.8 \\
29.2 \\
23.4 \\
18.4\end{array}$ & $\begin{array}{l}2001 \\
2001 \\
2000 \\
1998\end{array}$ \\
\hline 02253000 & Main Canal at Vero Beach, Florida & $1949-2008$ & $\begin{array}{l}\text { December } \\
\text { January } \\
\text { February } \\
\text { March } \\
\text { May } \\
\text { June } \\
\text { July } \\
\text { September }\end{array}$ & $\begin{array}{c}3.64 \\
4.04 \\
4.15 \\
4.11 \\
0.21 \\
0.00 \\
13.6 \\
0.83\end{array}$ & $\begin{array}{c}5.39 \\
15.8 \\
15.2 \\
6.62 \\
1.46 \\
24.4 \\
14.7 \\
27.2\end{array}$ & $\begin{array}{l}1956 \\
2007 \\
2007 \\
2007 \\
2007 \\
2000 \\
1997 \\
2002\end{array}$ \\
\hline 02312720 & $\begin{array}{l}\text { Withlacoochee River at Wysong Dam, } \\
\text { at Carlson, Florida }\end{array}$ & $1966-1980 ; 1982-2008$ & October & 43.5 & 55.8 & 2001 \\
\hline \multicolumn{7}{|c|}{ Southwest Florida } \\
\hline 02270000 & Carter Creek near Sebring, Florida & $1955-2008$ & $\begin{array}{l}\text { October } \\
\text { November } \\
\text { December } \\
\text { January } \\
\text { February } \\
\text { May }\end{array}$ & $\begin{array}{l}6.16 \\
4.67 \\
3.48 \\
3.93 \\
3.31 \\
1.24\end{array}$ & $\begin{array}{l}7.41 \\
5.80 \\
5.75 \\
5.35 \\
3.45 \\
1.62\end{array}$ & $\begin{array}{l}2007 \\
2001 \\
2001 \\
2001 \\
2001 \\
2007\end{array}$ \\
\hline 02294650 & Peace River at Bartow, Florida & $1940-2008$ & December & 5.19 & 6.67 & 2001 \\
\hline 02295420 & $\begin{array}{l}\text { Payne Creek near Bowling Green, } \\
\text { Florida }\end{array}$ & $1964-2008$ & December & 8.34 & 8.94 & 2001 \\
\hline 02298202 & Shell Creek near Punta Gorda, Florida & $1965-2008$ & November & 41.4 & 42.2 & 2001 \\
\hline 02303000 & $\begin{array}{l}\text { Hillsborough River near Zephyrhills, } \\
\text { Florida }\end{array}$ & $1940-2008$ & September & 90.2 & 91.9 & 1978 \\
\hline
\end{tabular}


Table 2. Stations reaching record-low monthly mean discharge and month(s) of occurrence during the 2008 water year and their previous record and year of occurrence.-Continued

[Discharge values listed in cubic feet per second]

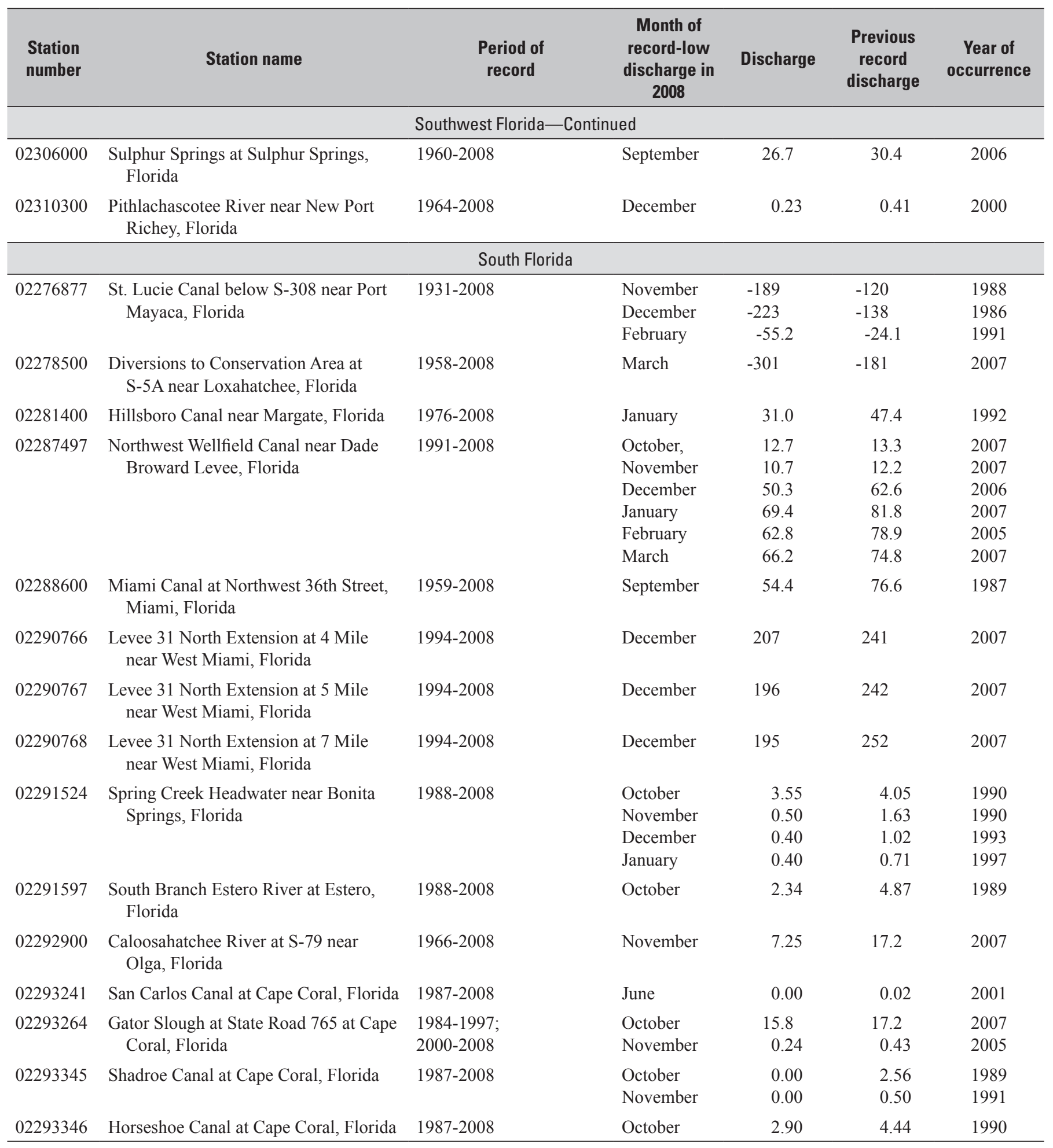


Table 3. Stations reaching record-high monthly mean discharge and month(s) of occurrence during the 2008 water year and their previous record and year of occurrence.

[Discharge values listed in cubic feet per second]

\begin{tabular}{|c|c|c|c|c|c|c|}
\hline \multicolumn{7}{|c|}{ Northwest Florida } \\
\hline 02326900 & St. Marks River near Newport, Florida & $\begin{array}{l}\text { 1957-1976; 1992-1994; } \\
\text { 1996-2008 }\end{array}$ & September & 1,660 & 1,560 & 1957 \\
\hline 02328522 & Ochlockonee River near Concord, Florida & 1999-2008 & August & 4,630 & 2,600 & 2003 \\
\hline 02329600 & Little River near Midway, Florida & $1986-2008$ & August & 1,740 & 1,620 & 1994 \\
\hline \multicolumn{7}{|c|}{ Northeast Florida } \\
\hline 02231000 & St. Mary's River near MacClenny, Florida & $1927-2008$ & August & 4,490 & 3,300 & 1945 \\
\hline 02231600 & Jane Green Creek near Deer Park, Florida & $1954-2008$ & August & 1,530 & 1,430 & 1964 \\
\hline 02232000 & St. John's River near Melbourne, Florida & $1940-2008$ & August & 2,910 & 2,700 & 2002 \\
\hline 02232400 & St. John's River near Cocoa, Florida & $1954-2008$ & September & 5,410 & 5,050 & 1960 \\
\hline 02233475 & $\begin{array}{l}\text { Little Econlockhatchee River at State Highway } \\
434 \text { near Oviedo, Florida }\end{array}$ & $1997-2008$ & August & 475 & 467 & 2004 \\
\hline 02233500 & Econlockhatchee River near Chuluota, Florida & $1936-2008$ & August & 1,900 & 1,440 & 2003 \\
\hline 02234000 & $\begin{array}{l}\text { St. John's River above Lake Harney near Geneva, } \\
\text { Florida }\end{array}$ & $1982-2008$ & September & 8,520 & 7,420 & 2004 \\
\hline 02234308 & Howell Creek near Altamonte Springs, Florida & $1997-2008$ & August & 76.0 & 72.3 & 2004 \\
\hline 02234500 & St. John's River near Sanford, Florida & $1987-1989 ; 1995-2008$ & September & 11,400 & 8,750 & 2002 \\
\hline 02235000 & Wekiva River near Sanford, Florida & $1936-2008$ & August & 630 & 592 & 2003 \\
\hline 02235200 & Blackwater Creek near Cassia, Florida & $\begin{array}{l}\text { 1962-1967; 1968-1969; } \\
\text { 1981-2008 }\end{array}$ & August & 236 & 166 & 2005 \\
\hline 02236000 & St. John's River near De Land, Florida & $1934-2008$ & September & 12,800 & 12,100 & 1960 \\
\hline 02236125 & St. John's River at Astor, Florida & $1994-2008$ & September & 13,600 & 9,460 & 2004 \\
\hline 02244040 & $\begin{array}{l}\text { St. John's River at Buffalo Bluff near Satsuma, } \\
\text { Florida }\end{array}$ & $1993-2008$ & September & 15,700 & 13,300 & 2004 \\
\hline 02245260 & Deep Creek at Spuds, Florida & $1992-2008$ & August & 345 & 343 & 2003 \\
\hline 02246025 & Black Creek near Doctor's Inlet, Florida & $\begin{array}{l}\text { 1982-1987; 1995-1997; } \\
\text { 2001-2008 }\end{array}$ & August & 1,920 & 1,050 & 1995 \\
\hline 02248000 & Spruce Creek near Samsula, Florida & $1951-2008$ & August & 217 & 181 & 1976 \\
\hline 02249007 & $\begin{array}{l}\text { Eau Gallie River at Heather Glen Circle at Mel- } \\
\text { bourne, Florida }\end{array}$ & $1991-2008$ & $\begin{array}{l}\text { July } \\
\text { August }\end{array}$ & $\begin{array}{l}31.5 \\
83.7\end{array}$ & $\begin{array}{l}30.5 \\
52.5\end{array}$ & $\begin{array}{l}2001 \\
1995\end{array}$ \\
\hline 02249500 & Crane Creek at Melbourne, Florida & $1951-1968 ; 2003-2008$ & August & 146 & 49.0 & 1966 \\
\hline
\end{tabular}


Table 3. Stations reaching record-high monthly mean discharge and month(s) of occurrence during the 2008 water year and their previous record and year of occurrence.-Continued

[Discharge values listed in cubic feet per second]

\begin{tabular}{|c|c|c|c|c|c|c|}
\hline \multicolumn{7}{|c|}{ Northeast Florida-Continued } \\
\hline 02250030 & Turkey Creek at Palm Bay, Florida & $\begin{array}{l}\text { 1981-1983; 1987-2006; } \\
\text { 2007-2008 }\end{array}$ & August & 874 & 725 & 1995 \\
\hline 02251000 & $\begin{array}{l}\text { South Prong St. Sebastian River near Sebastian, } \\
\text { Florida }\end{array}$ & $1994-2008$ & August & 378 & 319 & 1997 \\
\hline 02251500 & $\begin{array}{l}\text { North Prong St. Sebastian River near Micco, } \\
\text { Florida }\end{array}$ & $1987-2008$ & August & 258 & 152 & 1994 \\
\hline 02251767 & Fellsmere Canal near Micco, Florida & 1992-2008 & August & 334 & 211 & 2003 \\
\hline 02257000 & Fisheating Creek at Lakeport, Florida & $1949-1950 ; 1997-2008$ & August & 1,890 & 1,530 & 2001 \\
\hline \multicolumn{7}{|c|}{ South Florida } \\
\hline 02288900 & $\begin{array}{l}\text { Tamiami Canal Outlets, 40-Mile Bend to Monroe, } \\
\text { Florida }\end{array}$ & $1964-2008$ & September & 2,520 & 2,320 & 2005 \\
\hline 02291580 & North Branch Estero River at Estero, Florida & $1987-2008$ & May & 3.28 & 0.31 & 2005 \\
\hline 02293214 & Meade Canal at Cape Coral, Florida & $1987-2008$ & $\begin{array}{l}\text { April } \\
\text { September }\end{array}$ & $\begin{array}{l}9.17 \\
36.9\end{array}$ & $\begin{array}{l}5.06 \\
22.9\end{array}$ & $\begin{array}{l}2003 \\
1995\end{array}$ \\
\hline 02293240 & Aries Canal at Cape Coral, Florida & $1990-2008$ & $\begin{array}{l}\text { July } \\
\text { August }\end{array}$ & $\begin{array}{c}135 \\
87.2\end{array}$ & $\begin{array}{r}127 \\
86.6\end{array}$ & $\begin{array}{l}1999 \\
2004\end{array}$ \\
\hline
\end{tabular}




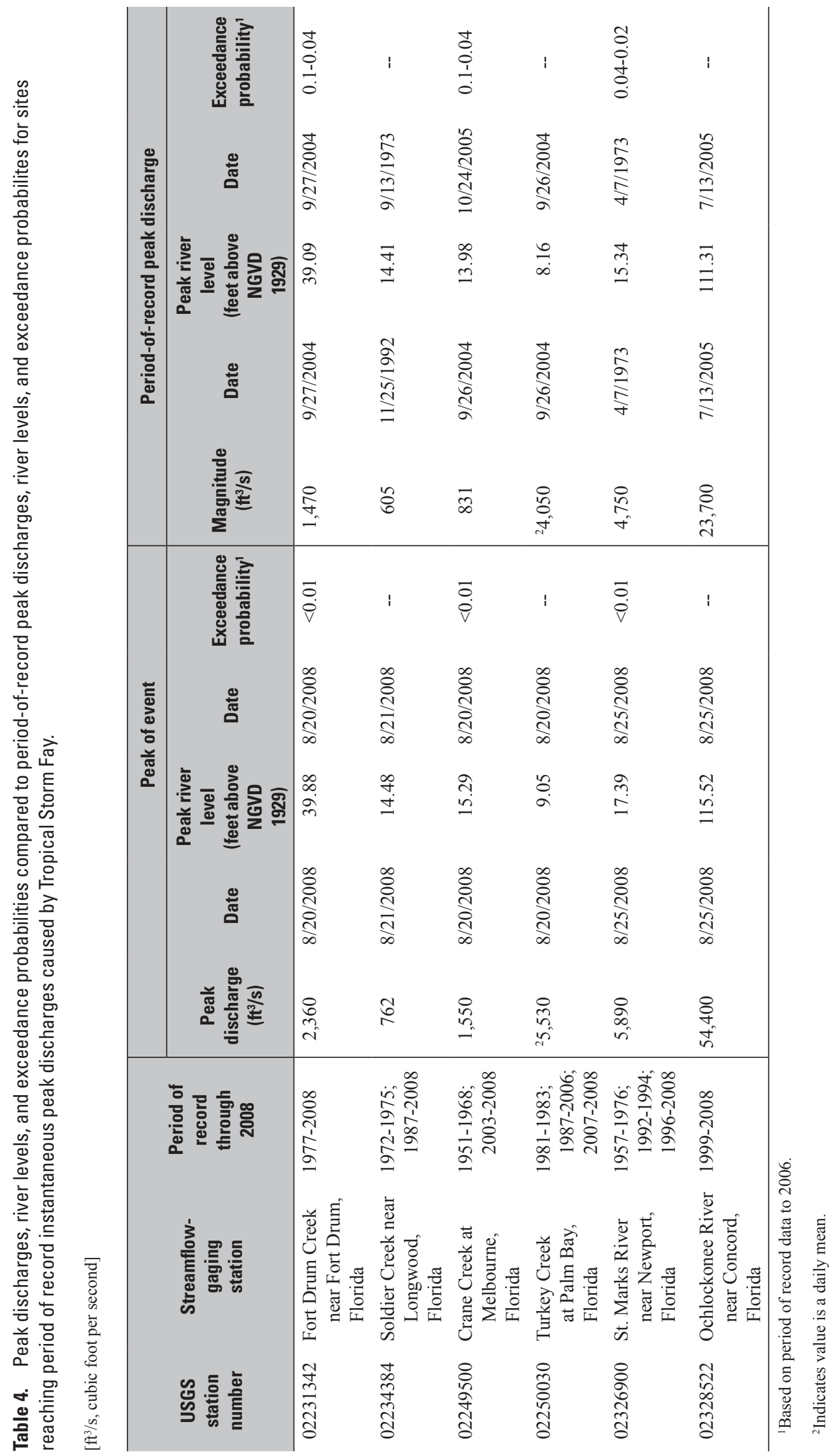




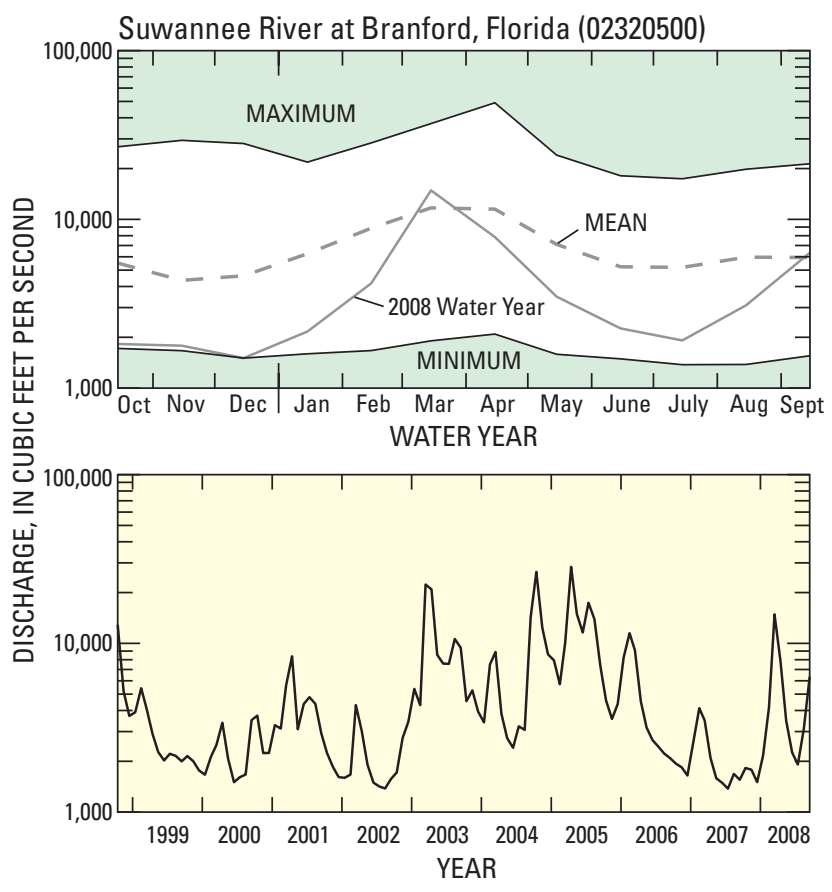

Figure 6. Suwannee River at Branford water year 2008 monthly mean discharge compared to the maximum, minimum, and mean monthly mean discharge for the period 1931-2008, and the monthly mean discharge for the period October 1998 to September 2008.

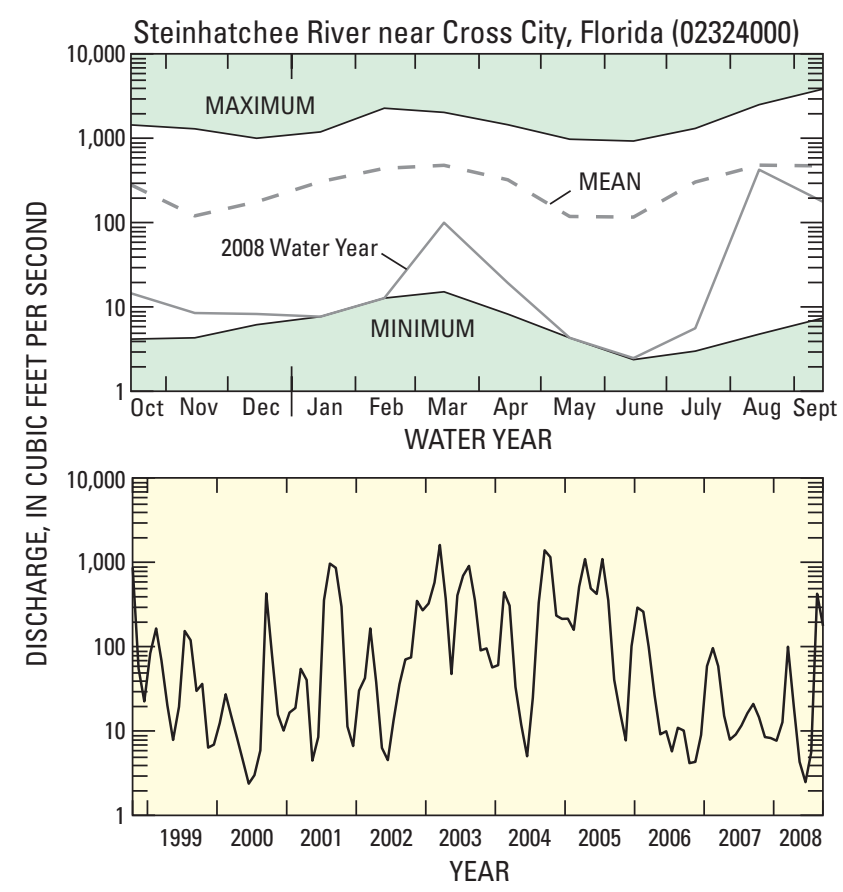

Figure 8. Steinhatchee River near Cross City water year 2008 monthly mean discharge compared to the maximum, minimum, and mean monthly mean discharge for the period 1950-2008, and the monthly mean discharge for the period October 1998 to September 2008.

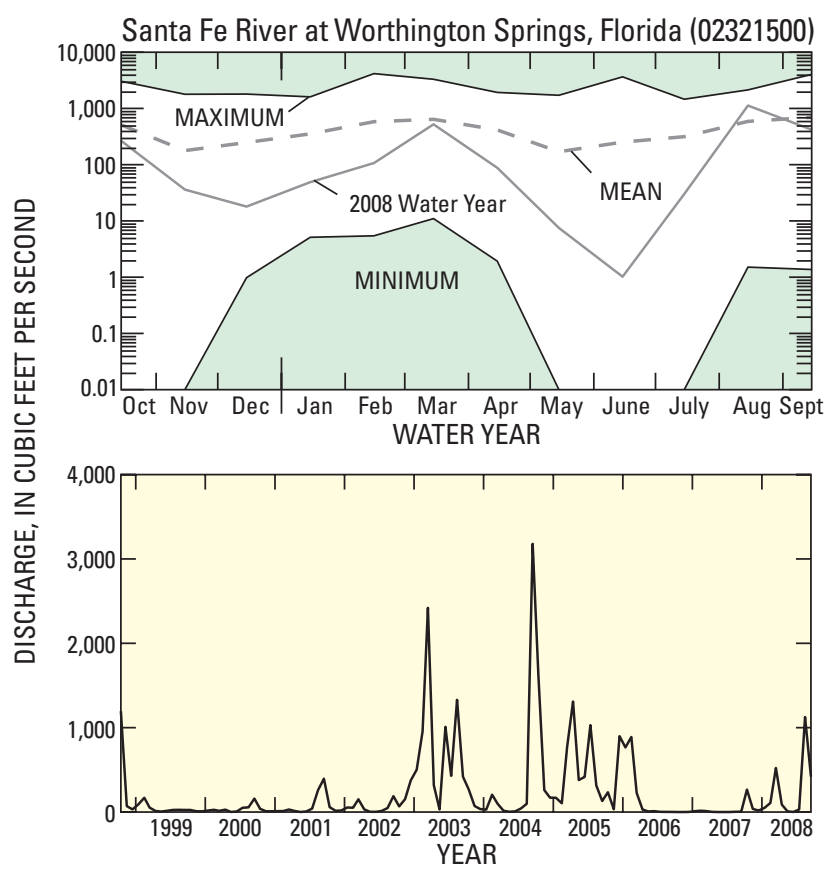

Figure 7. Santa Fe River at Worthington Springs water year 2008 monthly mean discharge compared to the maximum, minimum, and mean monthly mean discharge for the period 1932-2008, and the monthly mean discharge for the period October 1998 to September 2008.

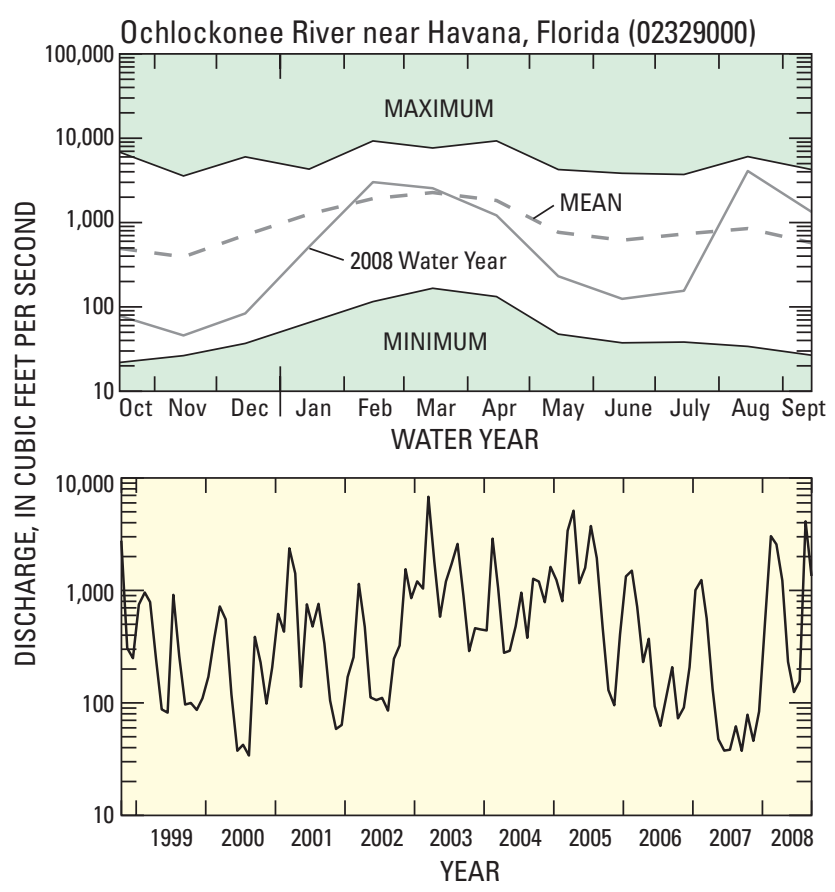

Figure 9. Ochlockonee River near Havana water year 2008 monthly mean discharge compared to the maximum, minimum, and mean monthly mean discharge for the period 1926-2008, and the monthly mean discharge for the period October 1998 to September 2008. 


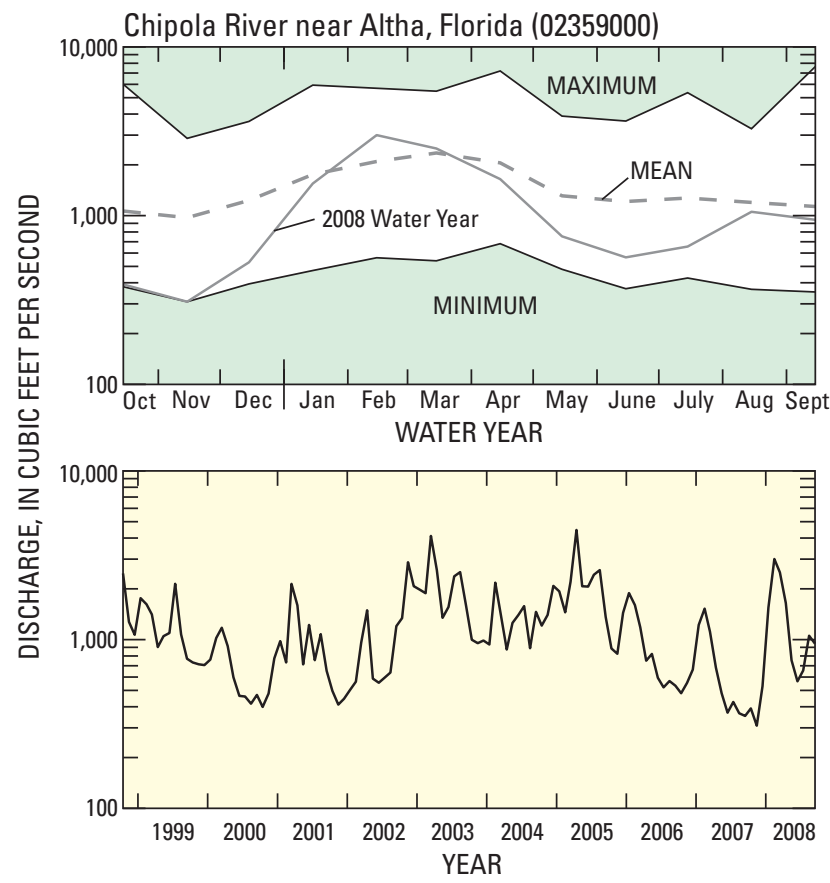

Figure 10. Chipola River near Altha water year 2008 monthly mean discharge compared to the maximum, minimum, and mean monthly mean discharge for the period 1913-2008, and the monthly mean discharge for the period October 1998 to September 2008.

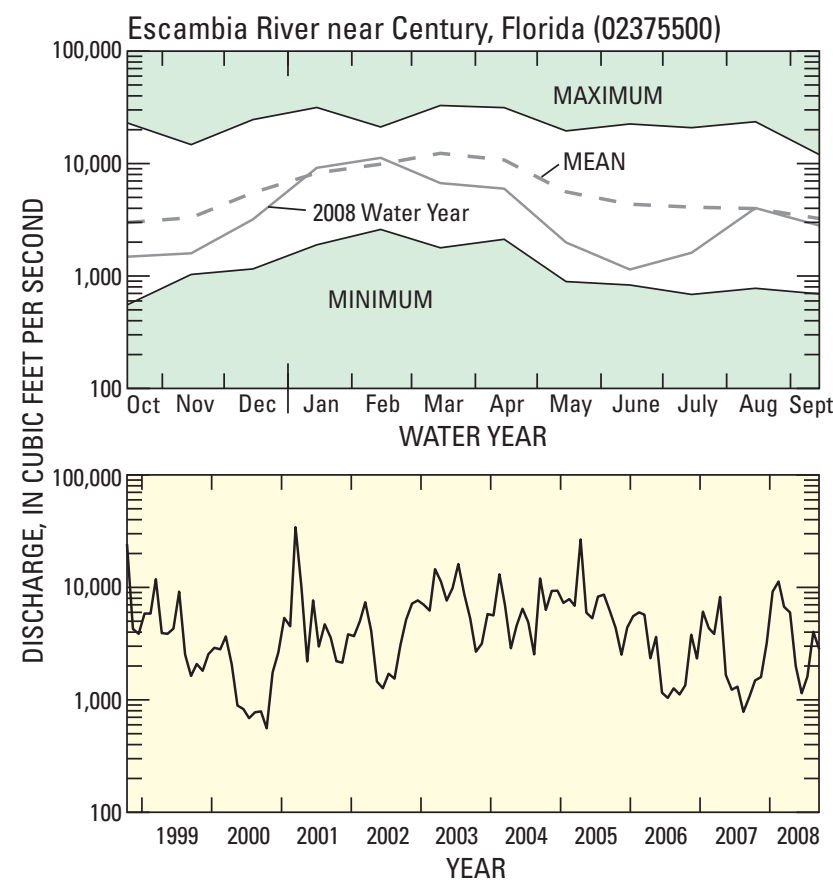

Figure 12. Escambia River near Century water year 2008 monthly mean discharge compared to the maximum, minimum, and mean monthly mean discharge for the period 1934-2008, and the monthly mean discharge for the period October 1998 to September 2008.

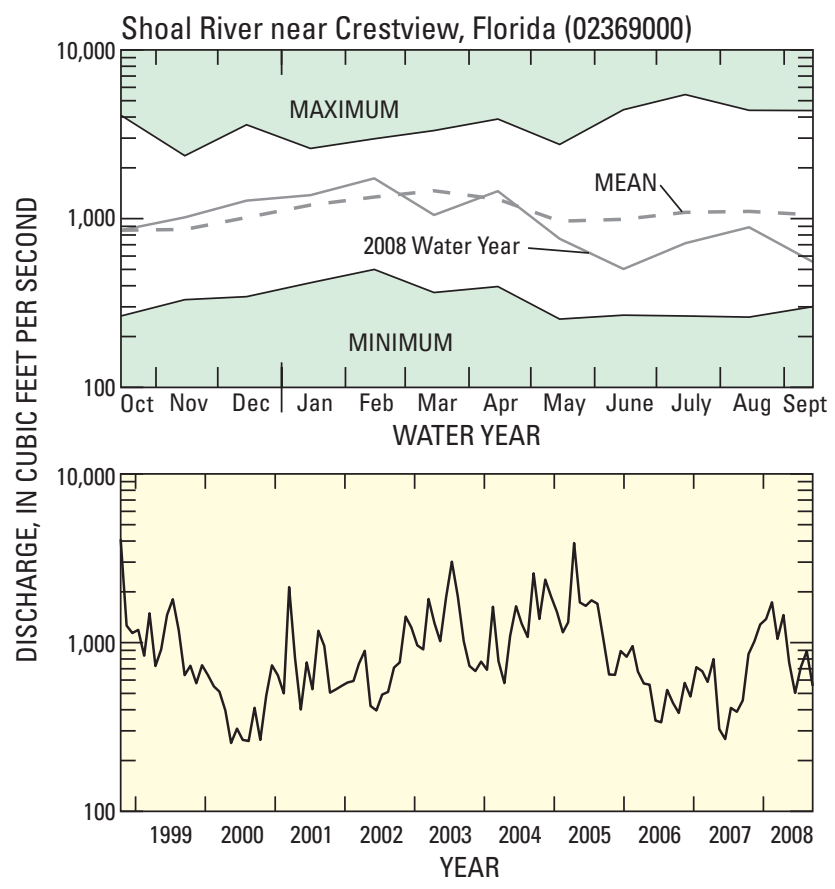

Figure 11. Shoal River near Crestview water year 2008 monthly mean discharge compared to the maximum, minimum, and mean monthly mean discharge for the period 1938-2008, and the monthly mean discharge for the period October 1998 to September 2008.

St. Marys River near MacClenny, Florida (02231000)

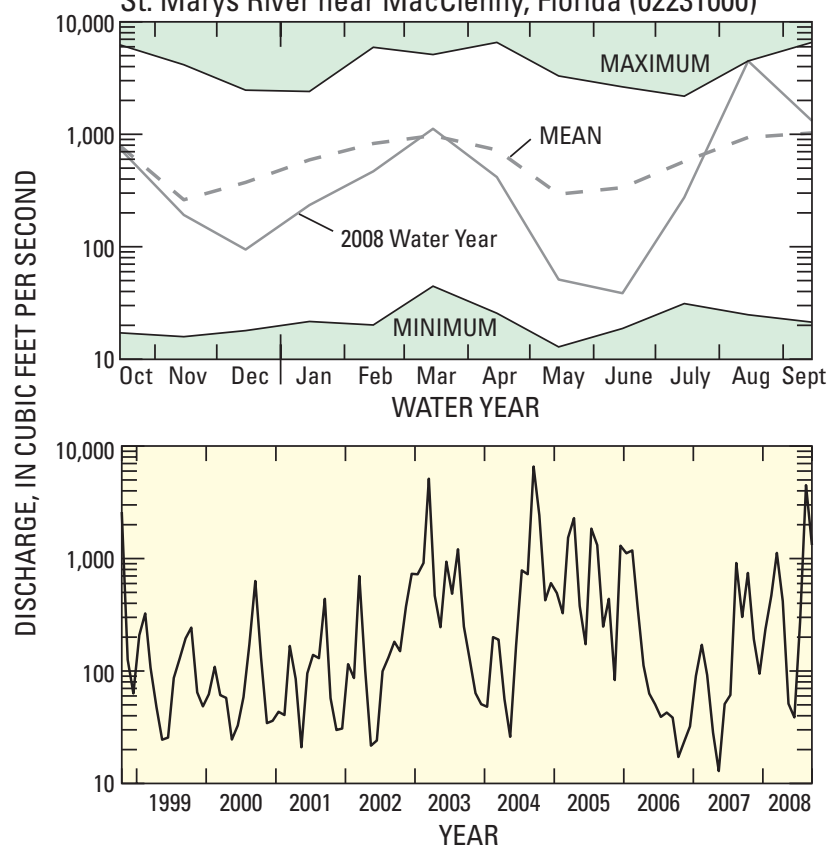

Figure 13. St. Mary's River near MacClenny water year 2008 monthly mean discharge compared to the maximum, minimum, and mean monthly mean discharge for the period 1927-2008, and the monthly mean discharge for the period October 1998 to September 2008. 


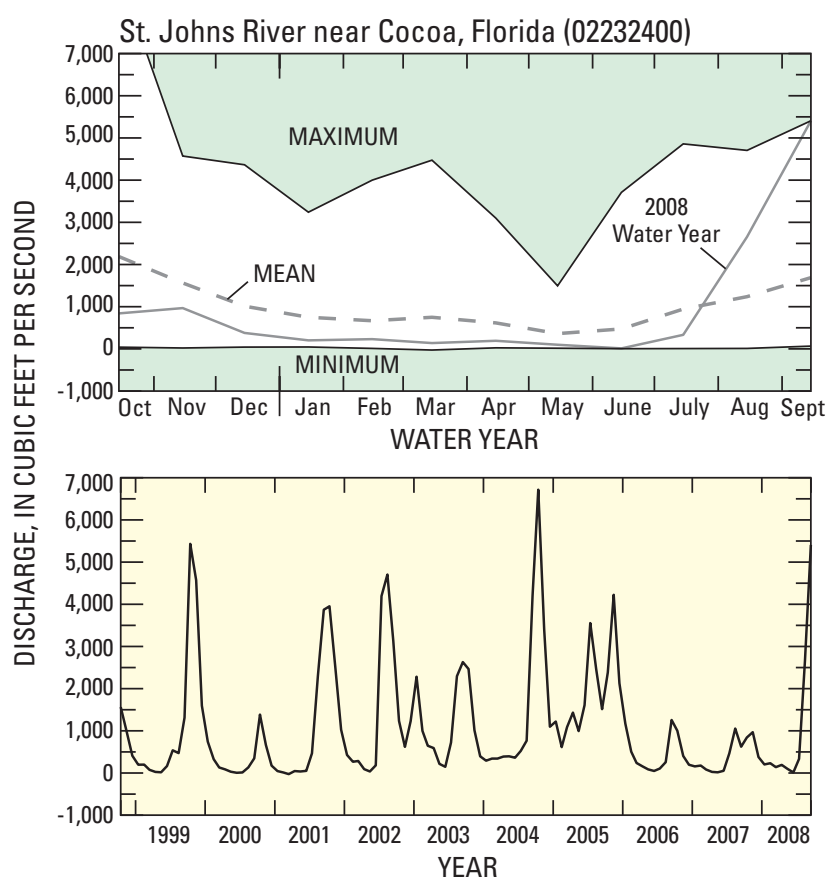

Figure 14. St. John's River near Cocoa water year 2008 monthly mean discharge compared to the maximum, minimum, and mean monthly mean discharge for the period 1954-2008, and the monthly mean discharge for the period October 1998 to September 2008.

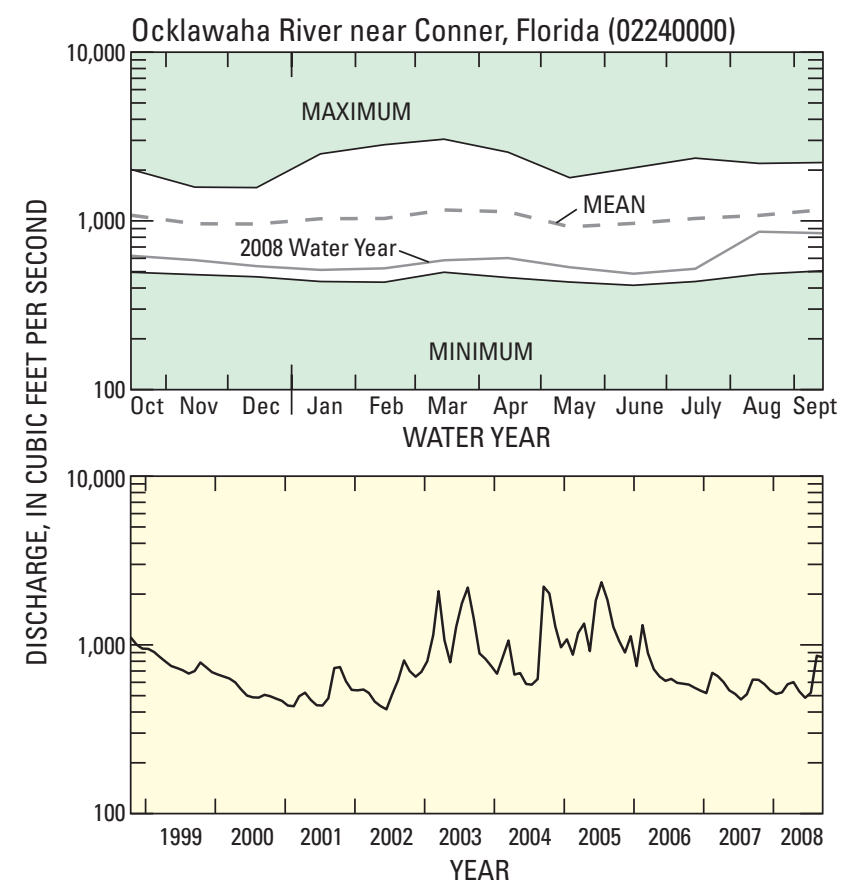

Figure 16. Ocklawaha River near Conner water year 2008 monthly mean discharge compared to the maximum, minimum, and mean monthly mean discharge for the period 1930-2008, and the monthly mean discharge for the period October 1998 to September 2008.

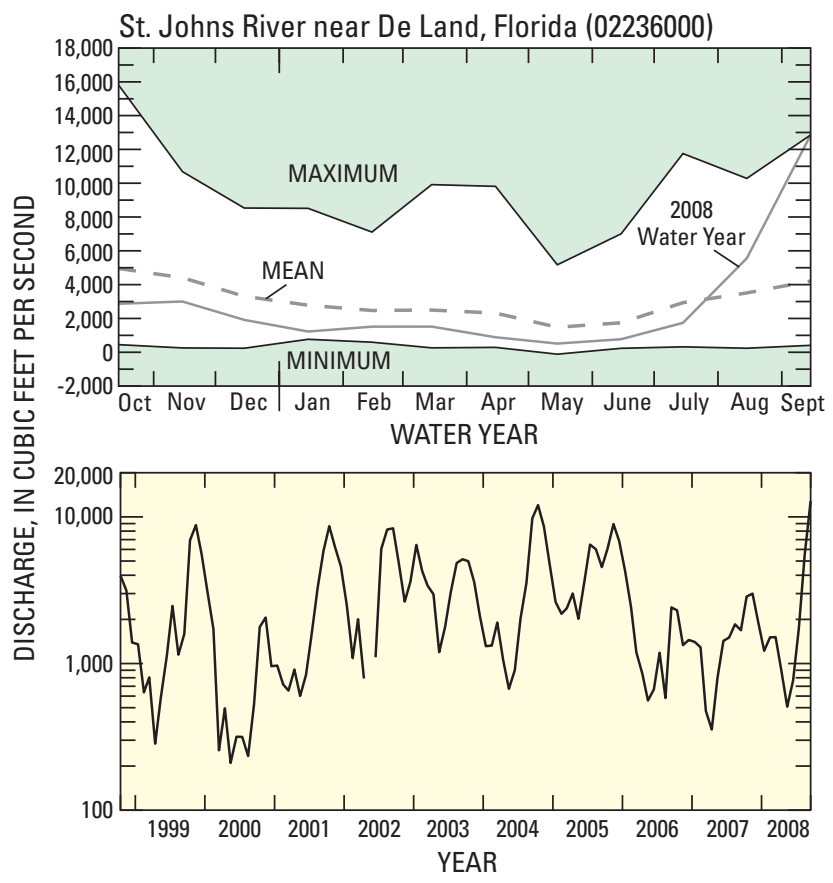

Figure 15. St. John's River near De Land water year 2008 monthly mean discharge compared to the maximum, minimum, and mean monthly mean discharge for the period 1934-2008, and the monthly mean discharge for the period October 1998 to September 2008.

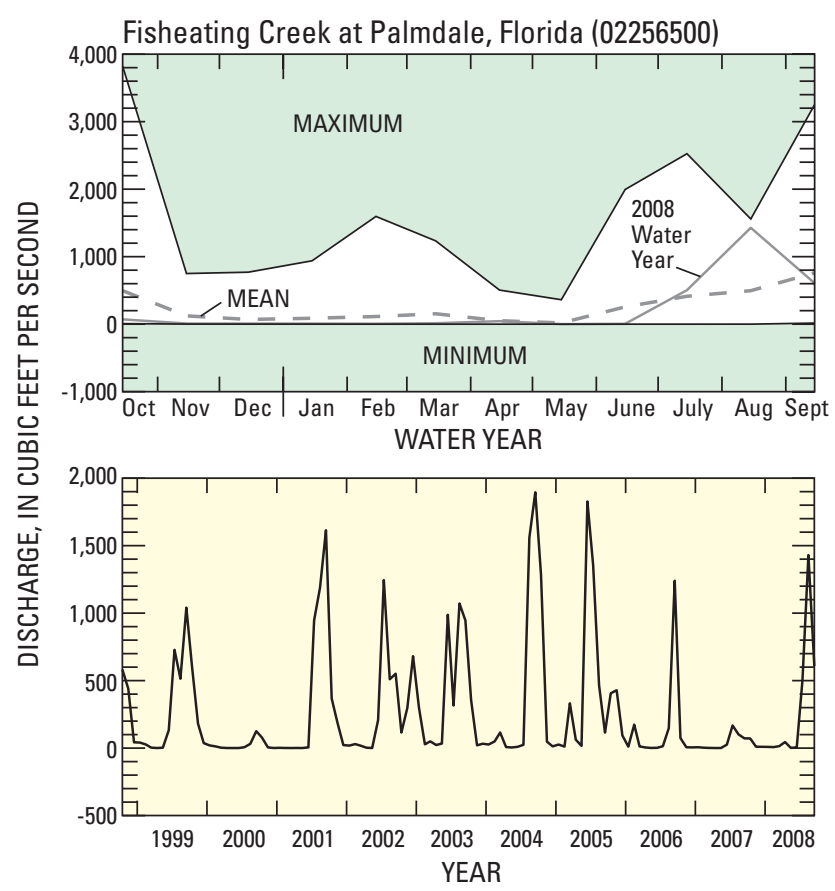

Figure 17. Fisheating Creek at Palmdale water year 2008 monthly mean discharge compared to the maximum, minimum, and mean monthly mean discharge for the period 1931-2008, and the monthly mean discharge for the period October 1998 to September 2008. 


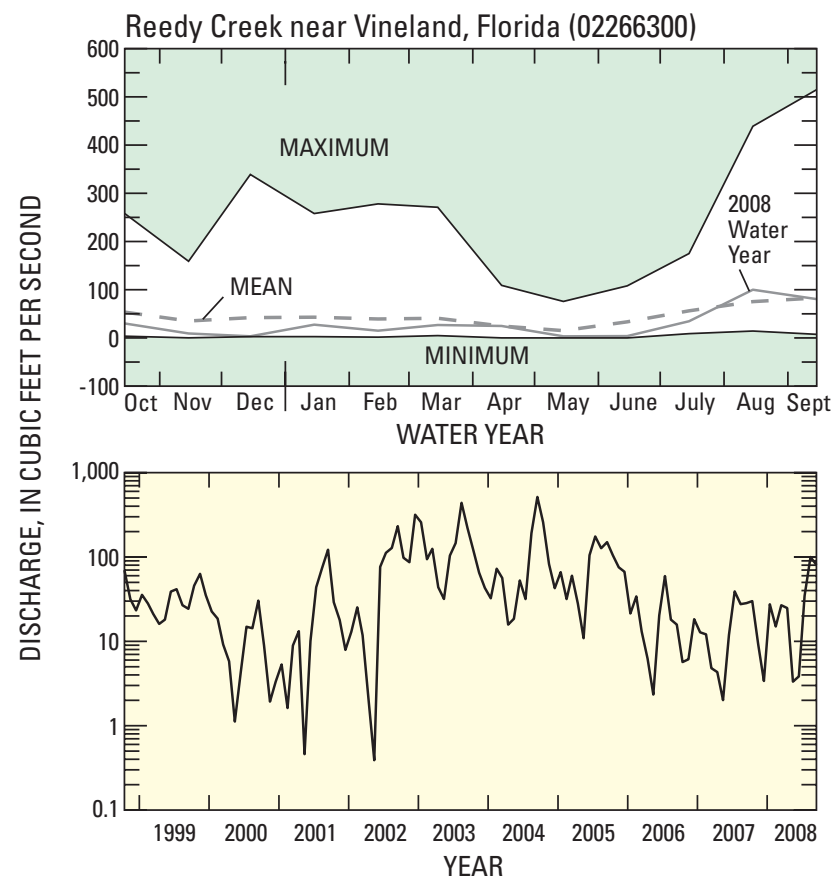

Figure 18. Reedy Creek near Vineland water year 2008 monthly mean discharge compared to the maximum, minimum, and mean monthly mean discharge for the period 1966-2008, and the monthly mean discharge for the period October 1998 to September 2008.

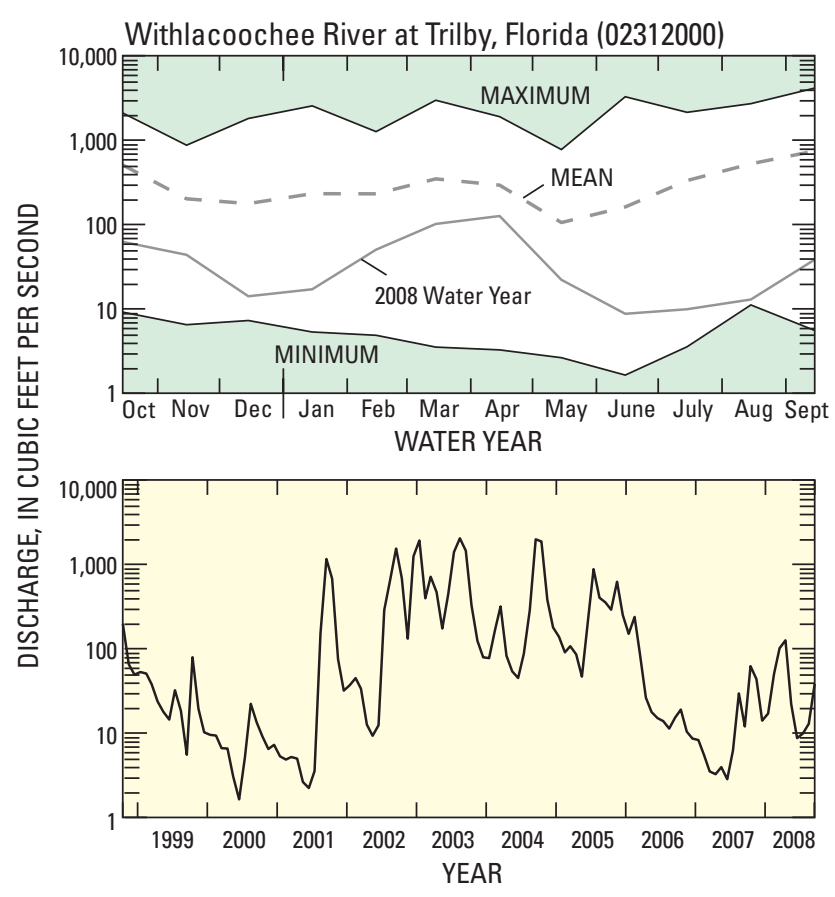

Figure 20. Withlacoochee River at Trilby water year 2008 monthly mean discharge compared to the maximum, minimum, and mean monthly mean discharge for the period 1928-2008, and the monthly mean discharge for the period October 1998 to September 2008.

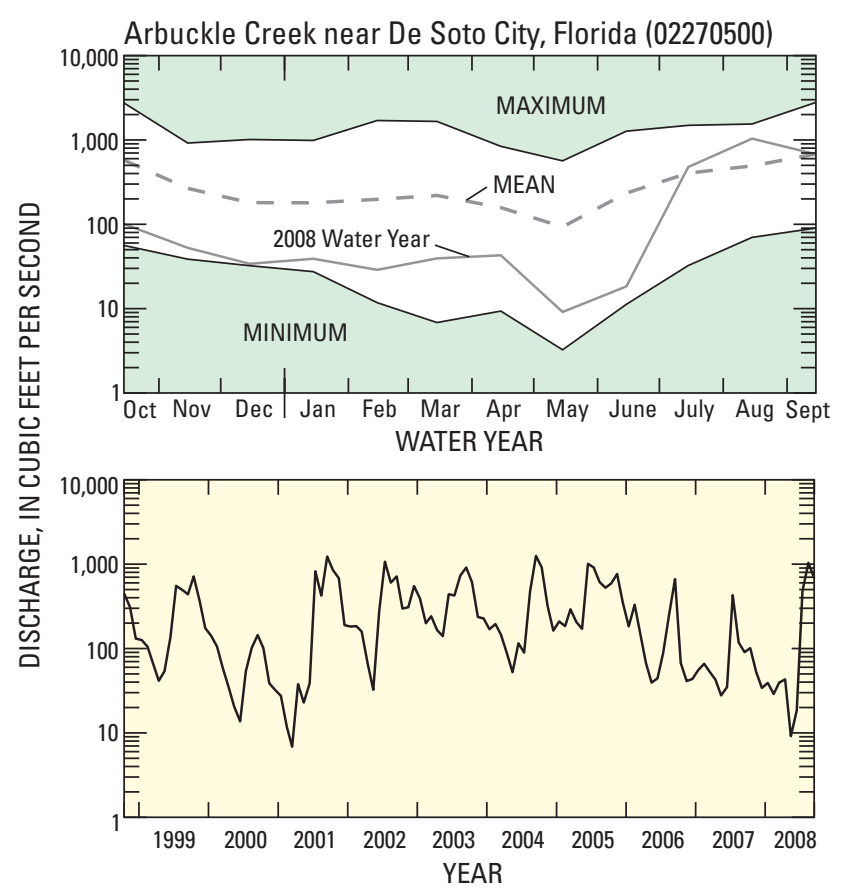

Figure 19. Arbuckle Creek near De Soto City water year 2008 monthly mean discharge compared to the maximum, minimum, and mean monthly mean discharge for the period 1939-2008, and the monthly mean discharge for the period October 1998 to September 2008.

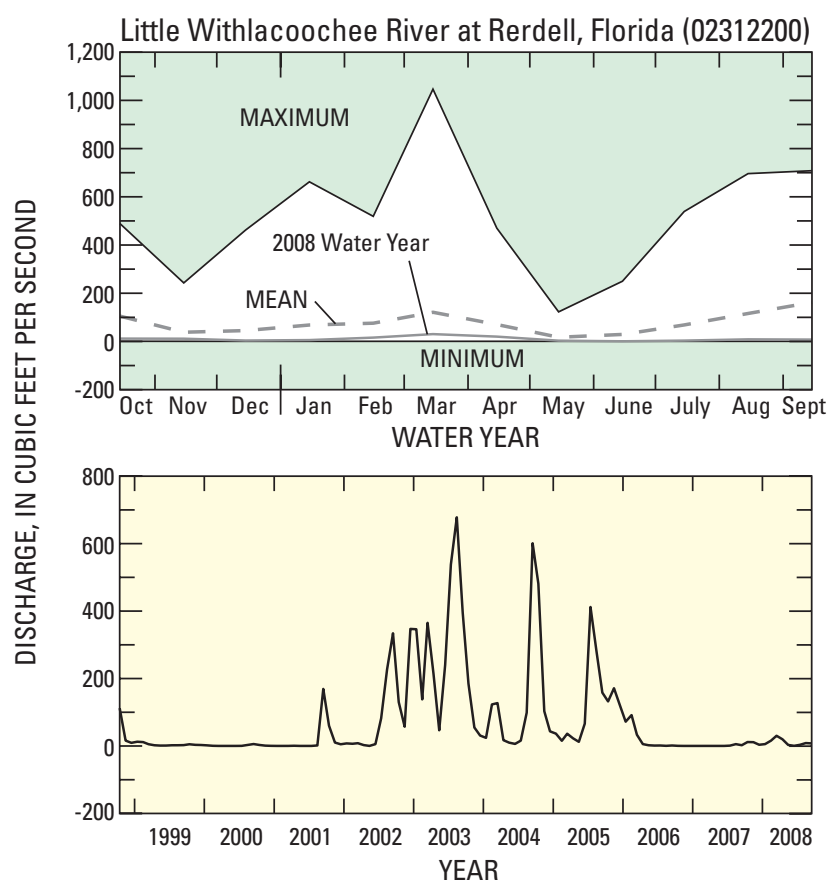

Figure 21. Little Withlacoochee River at Rerdell water year 2008 monthly mean discharge compared to the maximum, minimum, and mean monthly mean discharge for the period 1958-2008, and the monthly mean discharge for the period October 1998 to September 2008. 


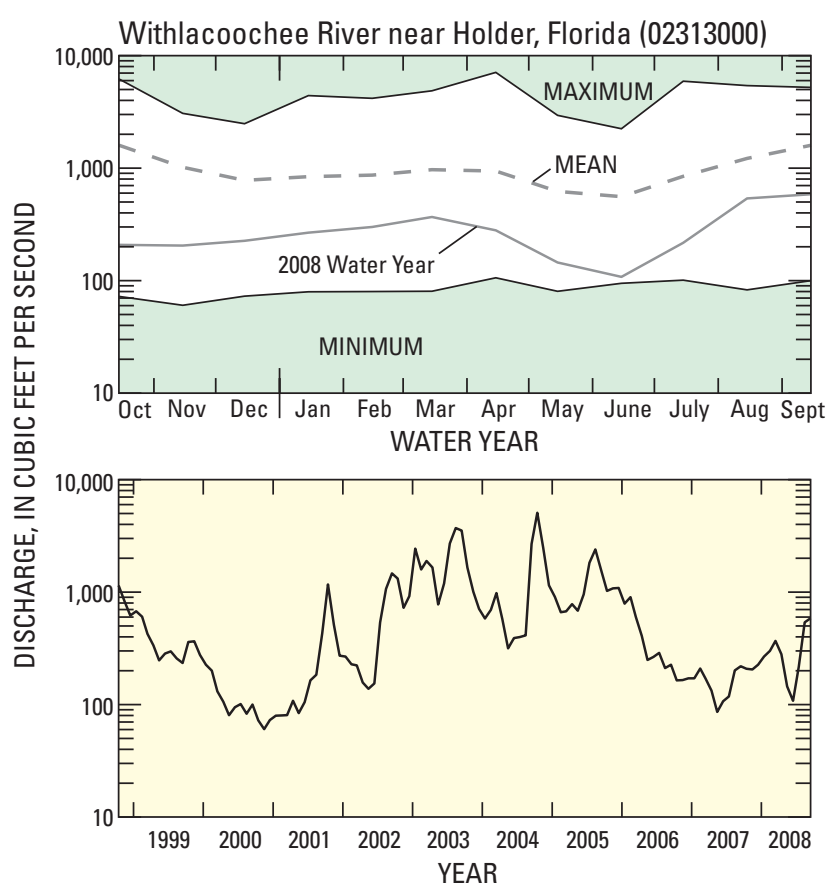

Figure 22. Withlacoochee River near Holder water year 2008 monthly mean discharge compared to the maximum, minimum, and mean monthly mean discharge for the period 1928-2008, and the monthly mean discharge for the period October 1998 to September 2008.

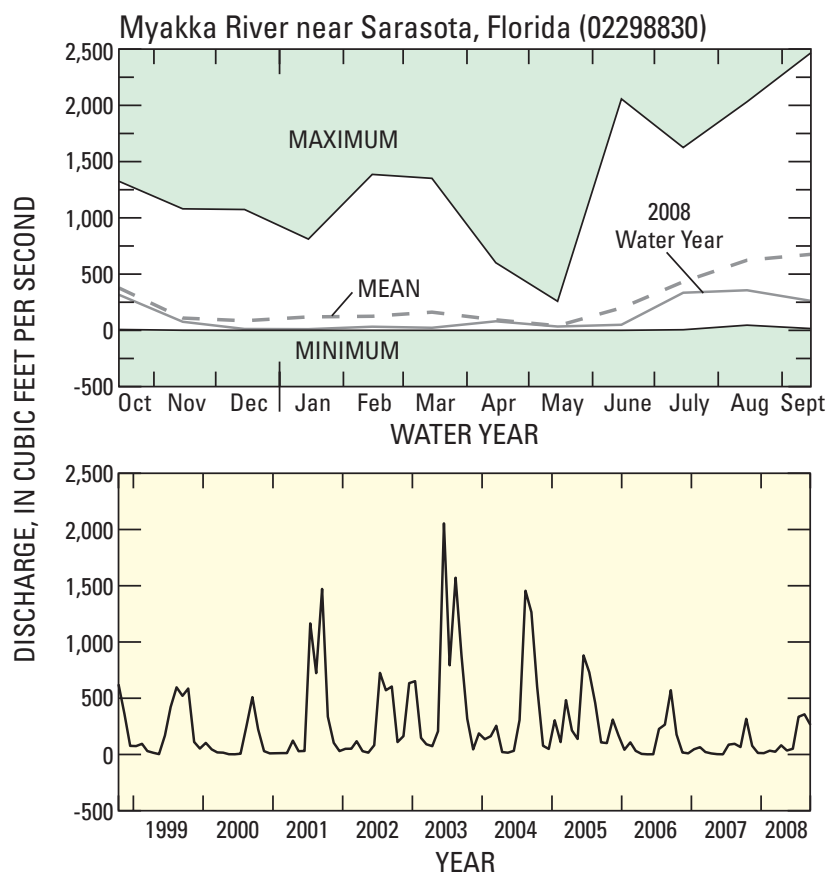

Figure 24. Myakka River near Sarasota water year 2008 monthly mean discharge compared to the maximum, minimum, and mean monthly mean discharge for the period 1937-2008, and the monthly mean discharge for the period October 1998 to September 2008.

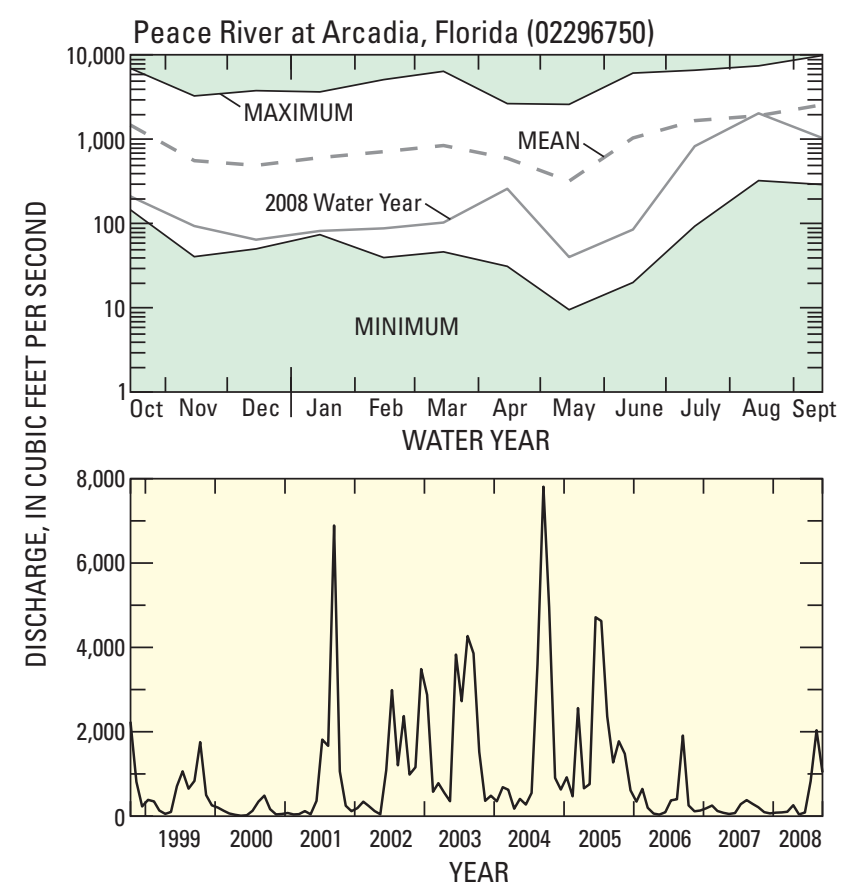

Figure 23. Peace River at Arcadia water year 2008 monthly mean discharge compared to the maximum, minimum, and mean monthly mean discharge for the period 1932-2008, and the monthly mean discharge for the period October 1998 to September 2008.

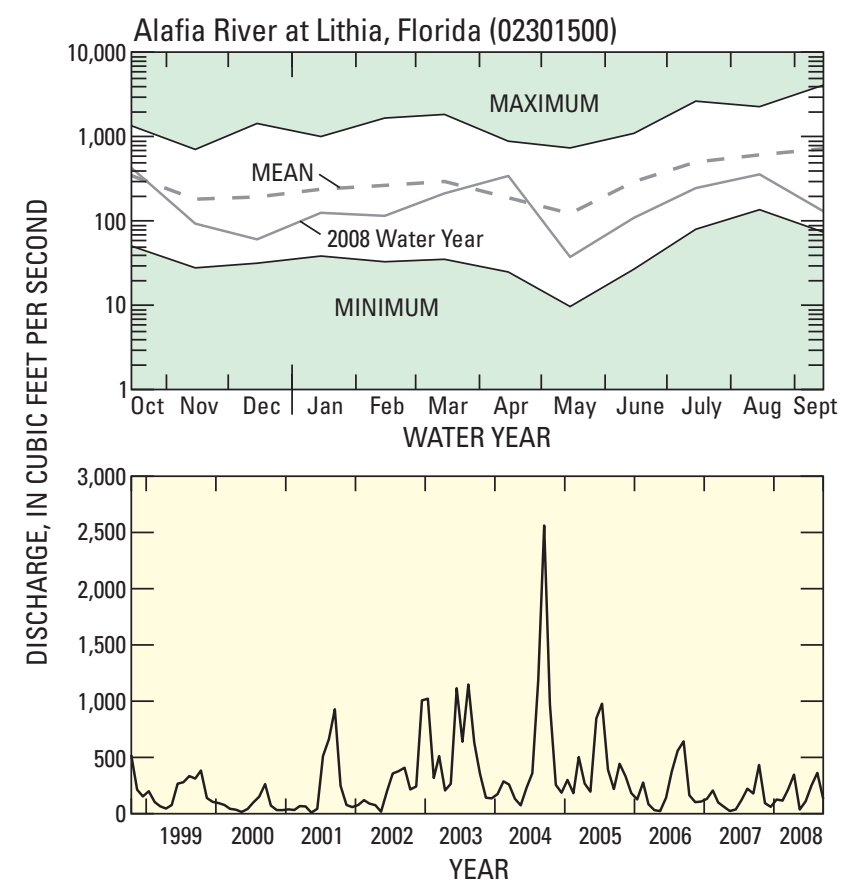

Figure 25. Alafia River at Lithia water year 2008 monthly mean discharge compared to the maximum, minimum, and mean monthly mean discharge for the period 1933-2008, and the monthly mean discharge for the period October 1998 to September 2008. 


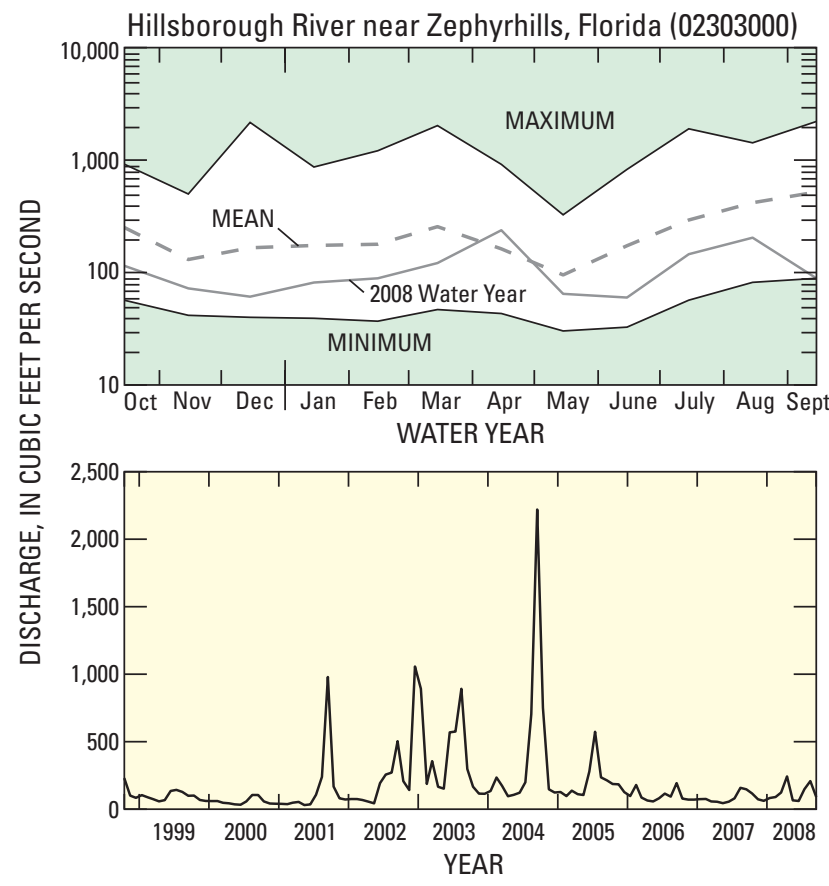

Figure 26. Hillsborough River near Zephyrhills water year 2008 monthly mean discharge compared to the maximum, minimum, and mean monthly mean discharge for the period 1940-2008, and the monthly mean discharge for the period October 1998 to September 2008.

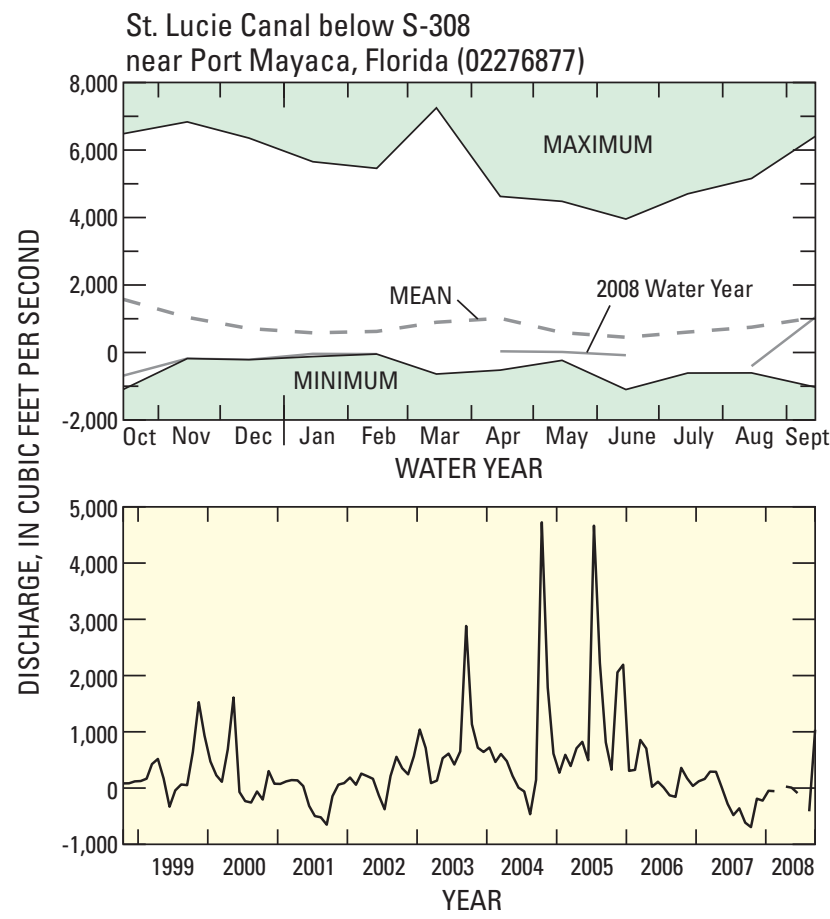

Figure 28. St. Lucie Canal below S-308 near Port Mayaca water year 2008 monthly mean discharge compared to the maximum, minimum, and mean monthly mean discharge for the period 1931-2008, and the monthly mean discharge for the period October 1998 to September 2008.

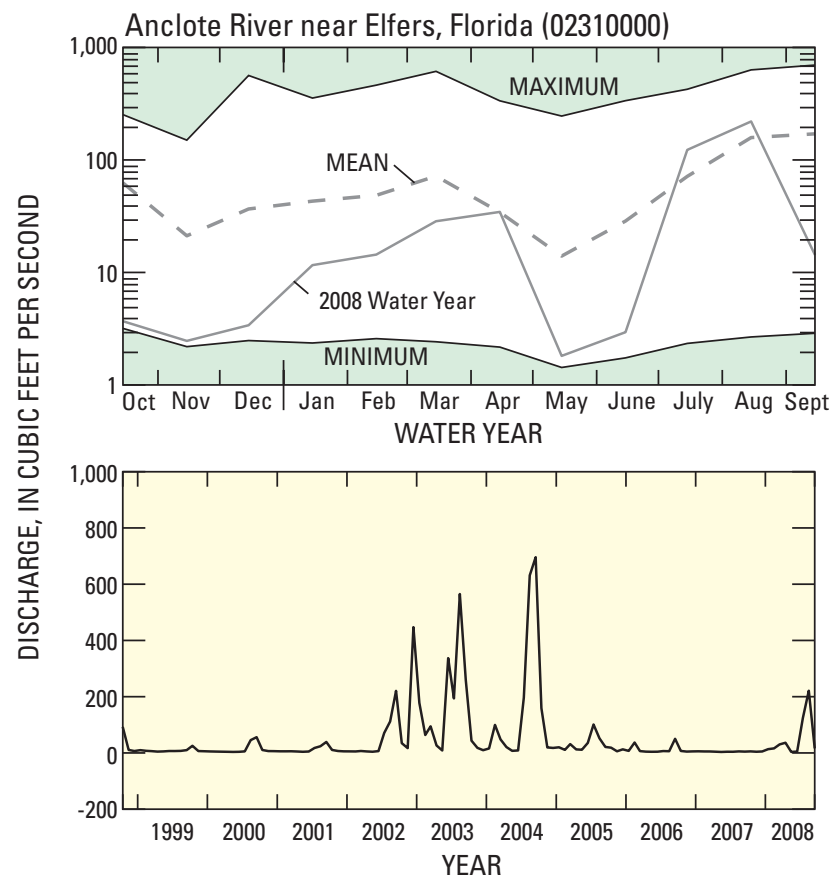

Figure 27. Anclote River near Elfers water year 2008 monthly mean discharge compared to the maximum, minimum, and mean monthly mean discharge for the period 1947-2008, and the monthly mean discharge for the period October 1998 to September 2008.

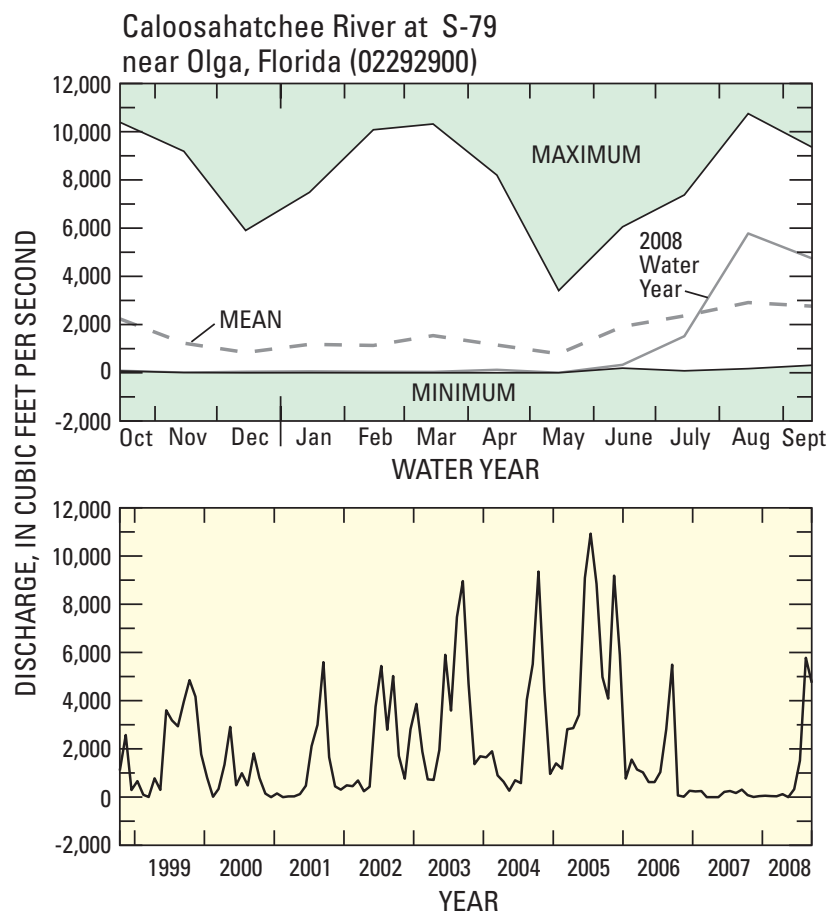

Figure 29. Caloosahatchee River at S-79 near Olga water year 2008 monthly mean discharge compared to the maximum, minimum, and mean monthly mean discharge for the period 1966-2008, and the monthly mean discharge for the period October 1998 to September 2008. 


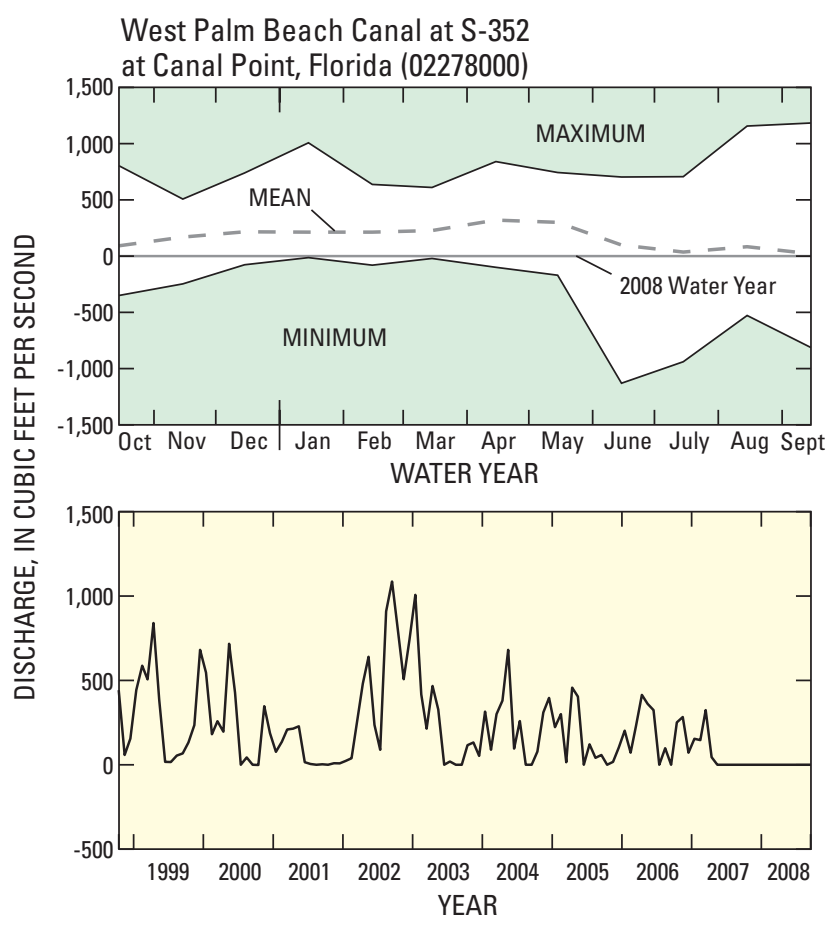

Figure 30. West Palm Beach Canal at S-352 at Canal Point water year 2008 monthly mean discharge compared to the maximum, minimum, and mean monthly mean discharge for the period 1940-2008, and the monthly mean discharge for the period October 1998 to September 2008.

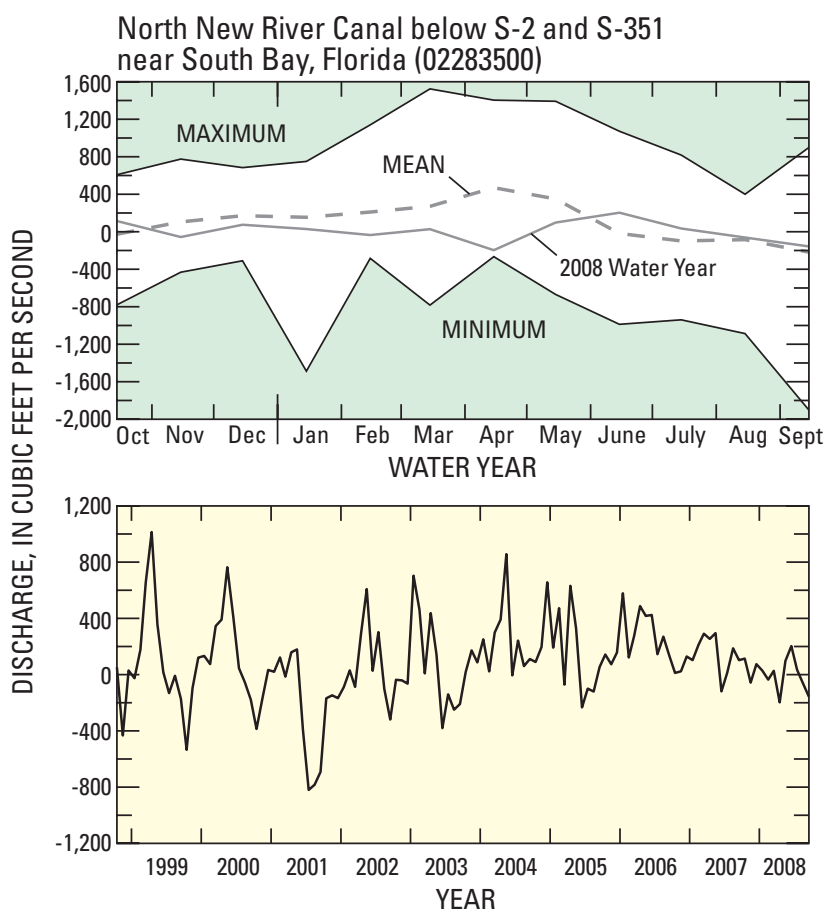

Figure 32. North New River Canal below S-2 and S-351 near South Bay water year 2008 monthly mean discharge compared to the maximum, minimum, and mean monthly mean discharge for the period 1957-2008, and the monthly mean discharge for the period October 1998 to September 2008.

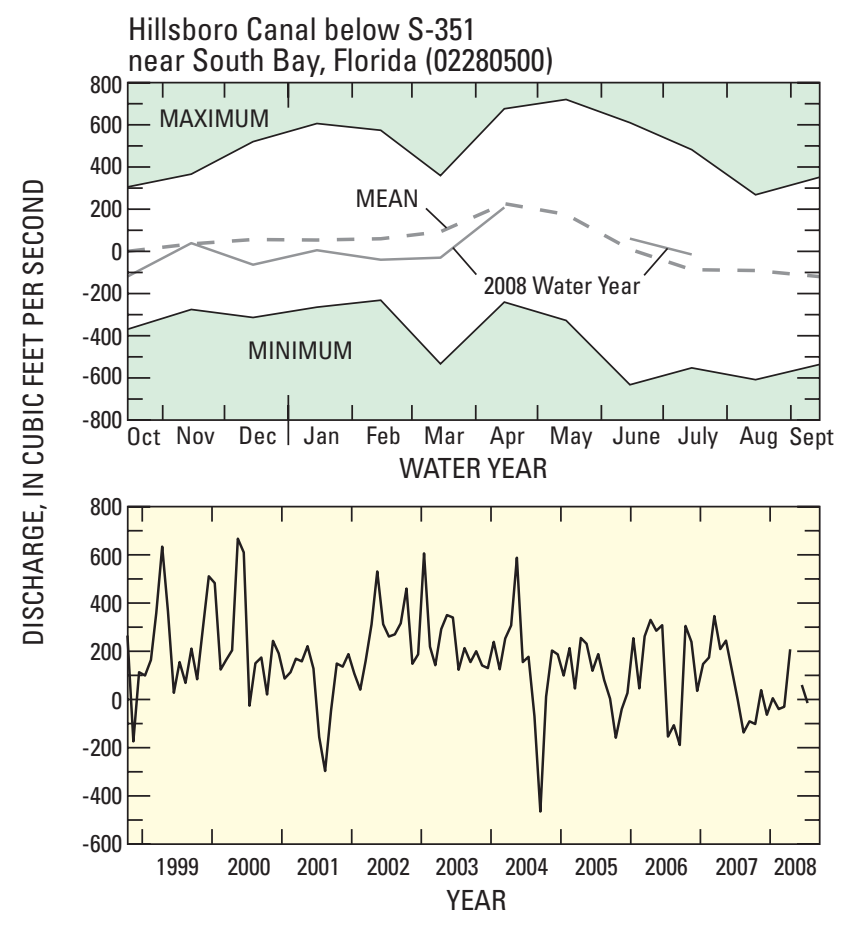

Figure 31. Hillsboro Canal below S-351 near South Bay water year 2008 monthly mean discharge compared to the maximum, minimum, and mean monthly mean discharge for the period 1957-2008, and the monthly mean discharge for the period October 1998 to September 2008.

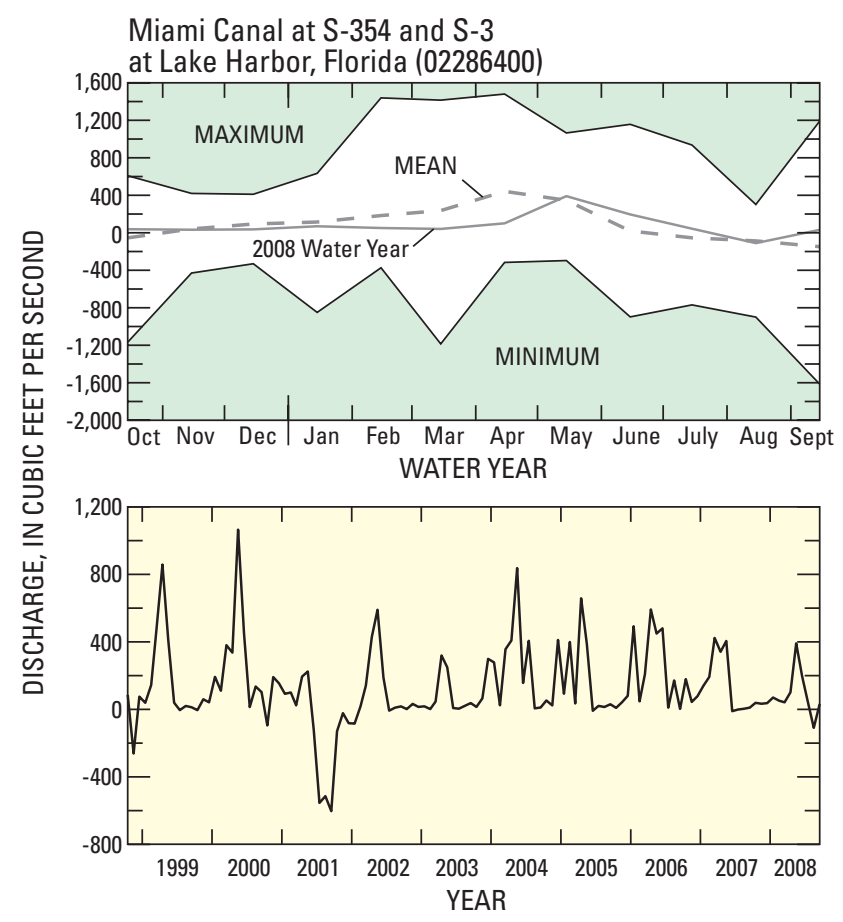

Figure 33. Miami Canal at S-354 and S-3 at Lake Harbor water year 2008 monthly mean discharge compared to the maximum, minimum, and mean monthly mean discharge for the period 1958-2008, and the monthly mean discharge for the period October 1998 to September 2008. 


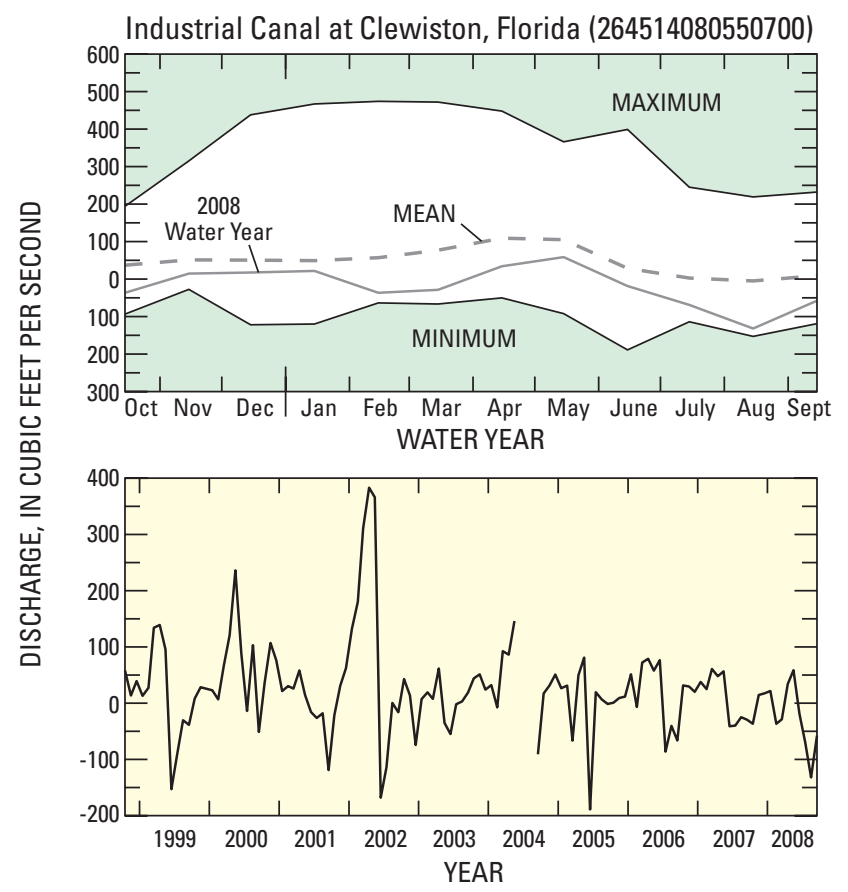

Figure 34. Industrial Canal at Clewiston water year 2008 monthly mean discharge compared to the maximum, minimum, and mean monthly mean discharge for the period 1976-2008, and the monthly mean discharge for the period October 1998 to September 2008.

\section{Northeast Florida}

Annual mean discharge across northeast Florida varied from well below normal to above normal during the 2008 water year, but well above the extremely dry conditions experienced during the previous water year (table 1). For example, the annual discharge at St. John's River near De Land (02236000) was $2,850 \mathrm{ft}^{3} / \mathrm{s}$, which is 93 percent of the period of record (1934-2008) average of 3,050 ft3/s (table 1). Annual discharge at Withlacoochee River at Trilby (02312000) was $42.6 \mathrm{ft}^{3} / \mathrm{s}$, which is 13 percent of the period of record average of $323 \mathrm{ft}^{3} / \mathrm{s}$ (table 1). Annual discharge at Reedy Creek near Vineland (02266300) was $30.1 \mathrm{ft}^{3} / \mathrm{s}$, which is 67 percent of the period of record (1966-2008) average of $45.2 \mathrm{ft}^{3} / \mathrm{s}$ (table 1).

Monthly mean discharges averaged well below normal during the months from October through July, but were near normal to above normal during August and September. Several streamgages throughout northeast Florida registered recordlow or record-high monthly mean discharges during the year (tables 2 and 3). Many streamgage locations recorded peakof-record discharges associated with the rainfall and runoff from Tropical Storm Fay (table 4). Figures 13-22 show the 10 representative streams in northeast Florida.

The dry conditions observed from October to July of the analysis period were caused by less than normal rainfall that had persisted throughout the region continuing from the 2007 water year. Several streamgage locations registered record-low monthly mean discharges during the year (table 2). For example, Crane Creek at Melbourne (02249500; period of record from 1951-1963 and 2003-2008) reached a record-low monthly mean discharge of $4.98 \mathrm{ft}^{3} / \mathrm{s}$ in March. The previous record there was $5.49 \mathrm{ft}^{3} / \mathrm{s}$ in 1968 (table 2). Outlet River at Panacoochee Retreats (02312700; period of record from 1963 to 2008$)$ reached a new low in October $\left(20.4 \mathrm{ft}^{3} / \mathrm{s}\right)$. The previous record was $31.6 \mathrm{ft}^{3} / \mathrm{s}$ set in 1964 (table 2).

Higher than normal monthly mean discharges during August and September were the direct result of Tropical Storm Fay moving through this part of Florida from August 19 to 22 (Verdi and Holt, 2010). Many streamgages in northeast Florida reached record-high monthly mean discharges during August or September, including some with a period of record greater than 70 years. For example, the St. John's River streamgage near De Land (02236000; period of record from 1934-2008), reached a new record-high monthly mean discharge of 12,800 ft $3 / \mathrm{s}$ in September (table 3). The previous record was 12,100 ft 3 /s set in 1960 (table 3). The St. Mary's River near MacClenny (02231000; period of record from 1927-2008) reached a new record-high monthly mean discharge of 4,490 ft $3 / \mathrm{s}$ in August (table 3). The previous record was $3,300 \mathrm{ft}^{3} / \mathrm{s}$ set in 1945 (table 3).

Several stations in northeast Florida recorded instantaneous peak of record, or other notable peak river levels and/or discharge as a direct result of Tropical Storm Fay. For example, Crane Creek at Melbourne (02249500; period of record from 1951-1968 and 2003-2008) recorded a peak discharge of 1,550 ft $\mathrm{ft}^{3} / \mathrm{s}$ on August 20. A discharge event of this magnitude has an exceedance probability of less than 0.01 , indicating the event has less than a one percent chance of occurring in any given year (table 4) (Verdi and Holt, 2010). The gage on Fort Drum Creek near Fort Drum (02231342; period of record from 1977-2008) recorded a peak discharge of $2,360 \mathrm{ft}^{3} / \mathrm{s}$ on August 20. A discharge event of this magnitude has an exceedance probability of less than 0.01 , indicating the event has less than a 1 percent chance of occurring in any given year (table 4) (Verdi and Holt, 2010). The Wekiva River near Sanford (02235000; period of record from 19362008) recorded its fourth highest peak discharge of $1,800 \mathrm{ft}^{3} / \mathrm{s}$ on August 22. A discharge event of this magnitude has an exceedance probability of 0.02 , indicating the event size has a 2 percent chance of occurring in any given year. The record peak of 2,060 ft $\mathrm{ft}^{3} / \mathrm{s}$ at the Wekiva gage was set during the flood of September 17, 1945 (Verdi and Holt, 2010).

\section{Southwest Florida}

Annual mean discharge across southwest Florida was below the normal for the majority of the 2008 water year (table 1), although discharge generally increased with respect to the previous year. The Peace River at Arcadia (02296750) recorded an annual mean discharge of $413 \mathrm{ft}^{3} / \mathrm{s}$, which is 38 percent of the 1932-2008 period of record average of $1,070 \mathrm{ft}^{3} / \mathrm{s}$. The Myakka River near Sarasota (02298830) reached an annual discharge of $133 \mathrm{ft}^{3} / \mathrm{s}$, which is 52 percent 
of the 1937-2008 period-of-record average discharge. The Anclote River near Elfers (02310000) registered an annual mean discharge of $38.8 \mathrm{ft}^{3} / \mathrm{s}$ which represents 61 percent of the 1947-2008 period-of-record mean, an increase from 5 percent in water year 2007. Figures $23-27$ show the five representative streams in southwest Florida.

Several streamgages reached new monthly minimum mean discharges for the year (table 2). For example, the Peace River at Bartow (02294650) reached a new minimum discharge for the month of December of $5.19 \mathrm{ft}^{3} / \mathrm{s}$. The previous record minimum for the month of December was $6.67 \mathrm{ft}^{3} / \mathrm{s}$ during the 2001 water year. Another example is the Hillsborough River near Zephyrhills (02303000) which reached a new minimum monthly discharge of $90.2 \mathrm{ft}^{3} / \mathrm{s}$ for September. The previous record was $91.9 \mathrm{ft}^{3} / \mathrm{s}$ during the 1978 water year.

The Weeki Wachee River near Brooksville (02310525) is used to determine spring flow from Weeki Wachee Springs, a first order magnitude spring located in western Hernando County. Spring flow is determined from the relationship between measured discharge and the elevation of a nearby artesian well. The annual mean discharge for the 2008 water year was $137 \mathrm{ft}^{3} / \mathrm{s}$, which was 87 percent of the mean flow, $157 \mathrm{ft}^{3} / \mathrm{s}$. Monthly mean discharge stayed well above the minimum during the water year.

\section{South Florida}

The drainage system below Lake Okeechobee in south Florida is almost completely controlled by locks and dams, thus making the computation and interpretation of statistical hydrologic information difficult. The St. Lucie Canal below S-308 and the Caloosahatchee River at S-79 are both gaged to monitor the release of water from Lake Okeechobee to the Atlantic Ocean and the Gulf of Mexico, respectively. The streamgages at the West Palm Beach Canal at S-352, Hillsboro Canal below S-351, North New River Canal below S-2 and S-351, Miami Canal at S-354 and S-3, and Industrial Canal at Clewiston monitor the release of water from Lake Okeechobee into the Everglades Agricultural Area.

Annual mean discharge in south Florida varied from well below normal to near normal for the year (table 1). For example, annual discharge at North New River Canal below S-2 and S-351 near South Bay (02283500) was $7.82 \mathrm{ft}^{3} / \mathrm{s}$, which is 7 percent of the period of record (1957-2008) average of $115 \mathrm{ft}^{3} / \mathrm{s}$ (table 1). Annual discharge at Miami Canal at S-354 and S-3 at Lake Harbor (02286400) was $77.0 \mathrm{ft}^{3} / \mathrm{s}$, which is 95 percent of the period of record (1958-2008) average of $81.3 \mathrm{ft}^{3} / \mathrm{s}$ (table 1 ).

Monthly mean discharges varied throughout the analysis period from below normal to above normal. Several streamgages reached record-low or record-high monthly mean discharges throughout the year (tables 2 and 3). Figures 28-34 show the seven representative streams in south Florida.

The dry conditions in the area are attributed to below normal rainfall leading up to and during the analysis period, causing some streamgages to reach record-low monthly mean discharges (table 2). For example, the St. Lucie Canal below S-308 near Port Mayaca (02276877; period of record from 1931-2008) reached record-low monthly discharges in November $\left(-189 \mathrm{ft}^{3} / \mathrm{s}\right)$, December $\left(-223 \mathrm{ft}^{3} / \mathrm{s}\right)$, and February $\left(-55.2 \mathrm{ft}^{3} / \mathrm{s}\right)$. The previous records were set in $1988\left(-120 \mathrm{ft}^{3} / \mathrm{s}\right)$, $1986\left(-138 \mathrm{ft}^{3} / \mathrm{s}\right)$, and $1991\left(-24.1 \mathrm{ft}^{3} / \mathrm{s}\right)$, respectively (table 2). The Caloosahatchee River at S-79 near Olga (02292900; period of record from 1966-2008) reached a record-low monthly discharge of $7.25 \mathrm{ft}^{3} / \mathrm{s}$ in November. The previous record was $17.2 \mathrm{ft}^{3} / \mathrm{s}$ set in 2007 (table 2). The Miami Canal at Northwest $36^{\text {th }}$ Street in Miami (02288600; period of record 1959-2008) reached a new record-low monthly mean discharge in September $\left(54.4 \mathrm{ft}^{3} / \mathrm{s}\right)$, indicating little to no impact from the landfall of Tropical Storm Fay. The previous record was $76.6 \mathrm{ft}^{3} / \mathrm{s}$, set in 1987 (table 2).

A few streamgages in south Florida reached recordhigh monthly mean discharges during the year (table 3 ). For example, the monthly mean discharge at North Branch Estero River at Estero (02291580; period of record from 1987-2008) reached $3.28 \mathrm{ft}^{3} / \mathrm{s}$ in May (table 3). The previous record was $0.31 \mathrm{ft}^{3} / \mathrm{s}$ in 2005 (table 3). Hermosa Canal at Cape Coral (02293347) reached a period of record (1987-2008) maximum monthly discharge of $163 \mathrm{ft}^{3} / \mathrm{s}$ in September. The previous record was $151 \mathrm{ft}^{3} / \mathrm{s}$ set in 2006 (table 3).

\section{Lake Elevations}

Lake-water elevations in Florida averaged below normal throughout the year, even setting period-of-record low elevations in south (each month from October to March) and southwest (each month from October to April) Florida. Figures 35-38 show four representative lakes in Florida.

\section{Northwest Florida}

Water elevations for Lake Talquin are controlled by the C.H. Corn Hydroelectric Dam located on the Ochlockonee River. The dam also regulates the flow into the Ochlockonee River near Bloxham. Monthly mean lake levels were very stable for the entire water year, ranging from $68.30 \mathrm{ft}$ in October to $68.57 \mathrm{ft}$ in December and April (fig. 35). The maximum instantaneous water level at Lake Talquin near Bloxham (02329900) for the water year was $69.29 \mathrm{ft}$ on February 23. The minimum instantaneous water level was $67.32 \mathrm{ft}$ on August 22. No new extremes were reached during the year.

\section{Northeast Florida}

Lake Minnehaha at Clermont (02236840; fig. 36) is a long-term station that represents lake levels in the Orlando area of northeast Florida. Water levels generally declined from October to June and steadily increased from June to September due to the lack of rainfall during the year and runoff 


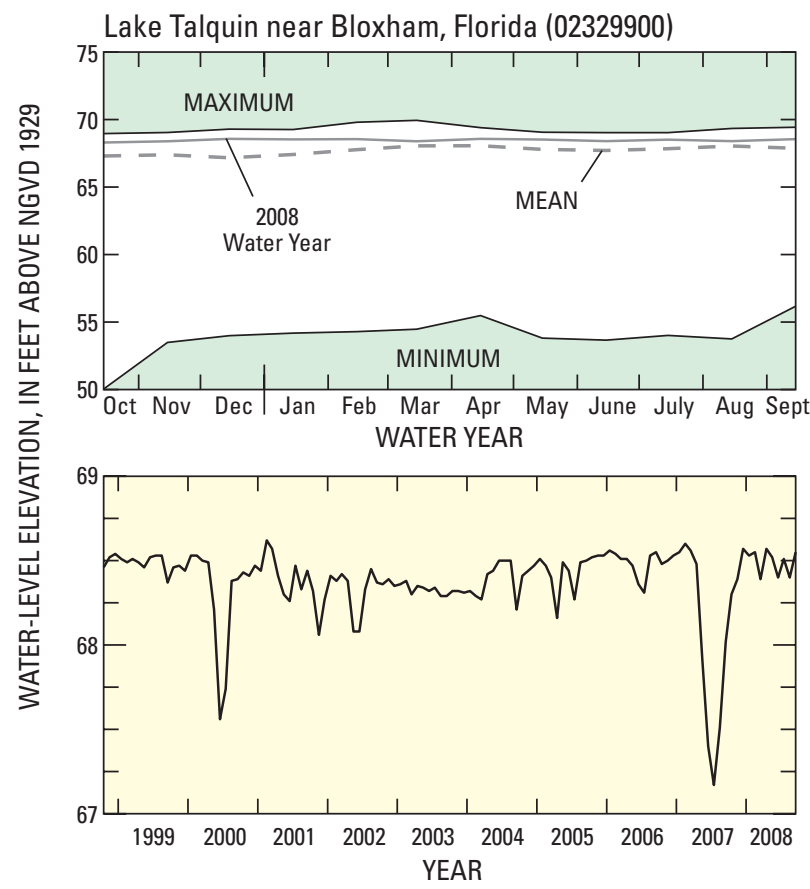

Figure 35. Lake Talquin near Bloxham water year 2008 monthly mean elevation compared to the maximum, minimum, and mean monthly mean elevation for the period 1930-2008, and the monthly mean elevation for the period October 1998 to September 2008.

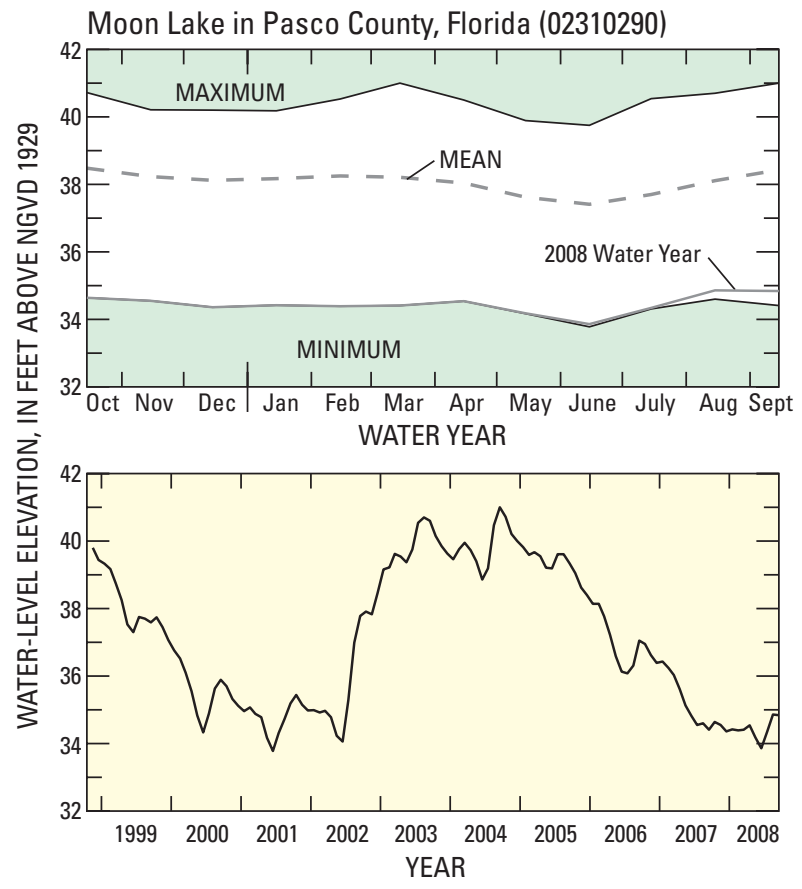

Figure 37. Moon Lake in Pasco County water year 2008 monthly mean elevation compared to the maximum, minimum, and mean monthly mean elevation for the period 1965-2008, and the monthly mean elevation for the period October 1998 to September 2008.

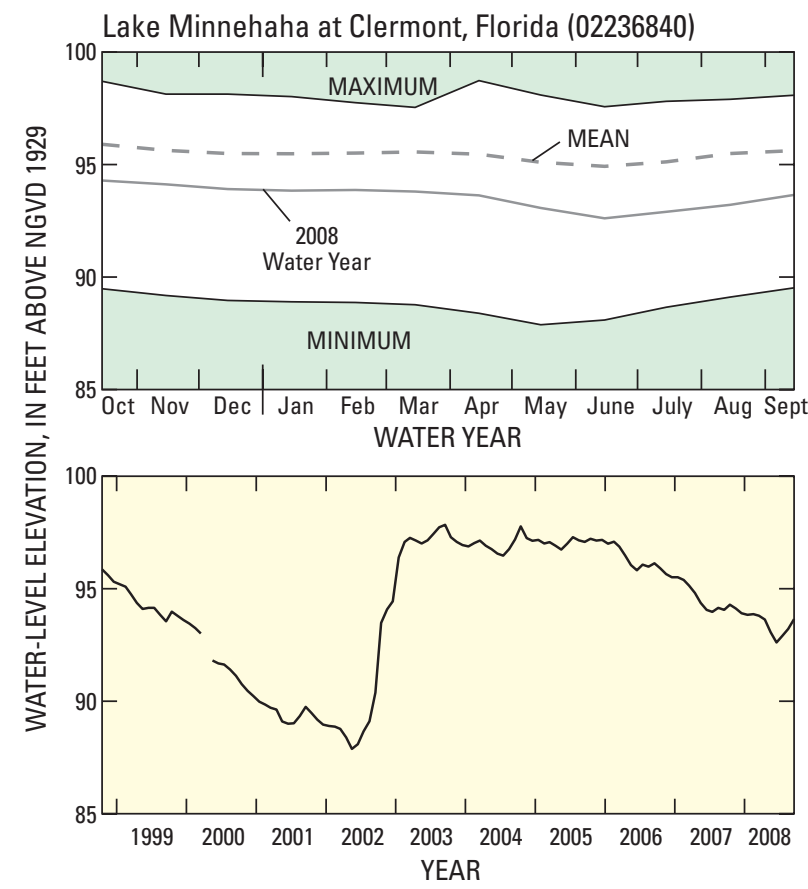

Figure 36. Lake Minnehaha at Clermont water year 2008 monthly mean elevation compared to the maximum, minimum, and mean monthly mean elevation for the period 1947-2008, and the monthly mean elevation for the period October 1998 to September 2008.

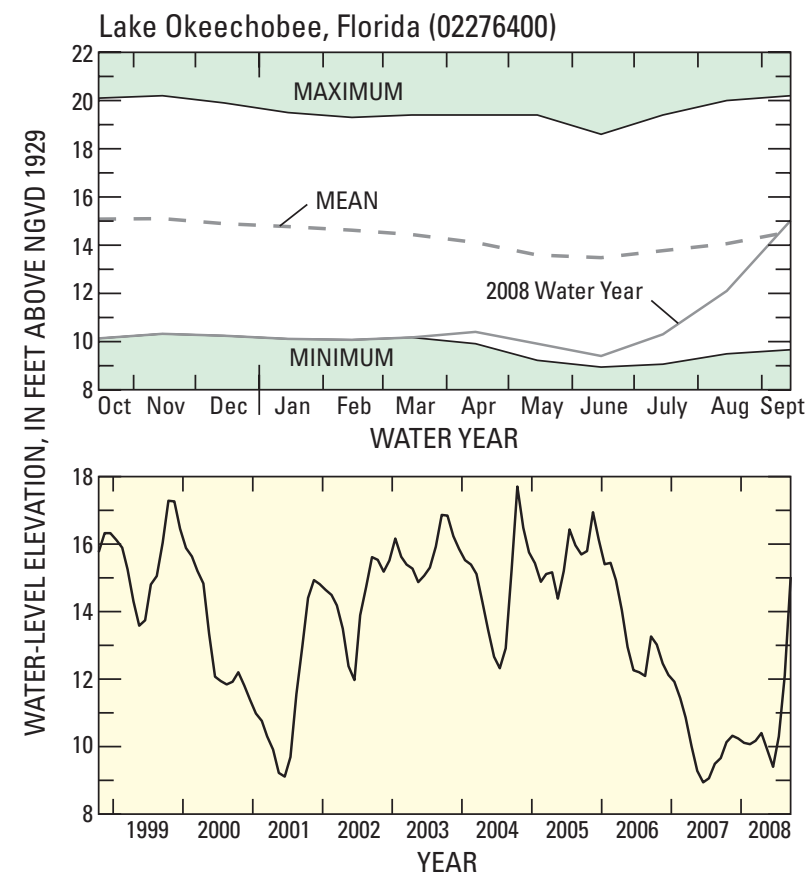

Figure 38. Lake Okeechobee water year 2008 monthly mean elevation compared to the maximum, minimum, and mean monthly mean elevation for the period 1912-2008, and the monthly mean elevation for the period October 1998 to September 2008. 
associated with the landfall of Tropical Storm Fay in August. The maximum instantaneous water level recorded during the year was $94.48 \mathrm{ft}$ on October 21. The minimum instantaneous water level recorded was $92.45 \mathrm{ft}$ on June 15 . No new extremes were reached during the year.

\section{Southwest Florida}

Moon Lake in Pasco County (02310290) is a long-term station used to monitor variation in lake levels in the southwest-central Florida region. Lake elevations are determined from instantaneous readings by USGS personnel and outside observers. Monthly mean elevations for the 2008 water year represented new monthly minimum elevations from October to April. Lake elevations began to increase slightly in June, but remained well below normal for the remainder of the water year. A new 1965-2008 period of record minimum elevation of $33.49 \mathrm{ft}$ was observed on June 13 (fig. 37). The previous record minimum was $33.60 \mathrm{ft}$ June 20, 2001.

\section{South Florida}

Lake levels in south Florida are mostly represented by the 730- $\mathrm{mi}^{2}$ (square mile) Lake Okeechobee (02276400; fig. 38), which has been monitored since 1912 and is managed by the U.S. Army Corps of Engineers. Lake Okeechobee monthly mean water levels varied within a 1.00-ft range from October to July, ranging from $9.40 \mathrm{ft}$ in June to $10.40 \mathrm{ft}$ in April. New minimum monthly mean lake levels were recorded each month from October through March (fig. 38). However, extensive rainfall and runoff in the Kissimmee River Valley, and direct rainfall in the lake, associated with the landfall of Tropical Storm Fay in the middle of August recharged lake levels to above $15.00 \mathrm{ft}$ by the middle of September (fig. 38) (Stewart and Beven, 2009; Verdi and Holt, 2010). The maximum instantaneous elevation during the year was $15.16 \mathrm{ft}$ on September 15-17. The minimum instantaneous elevation was $9.25 \mathrm{ft}$ on June 17.

\section{Groundwater}

Groundwater levels across the State varied throughout the year from well below normal to above normal. Figures 39-60 show hydrographs from 22 representative wells throughout Florida showing historical water-level summary and observed daily maximum water levels (top graph) during the 2008 water year and historical daily maximum water levels, annual means of daily maximum water levels, and results of Seasonal Kendall Trend Test (bottom graph).

The nonparametric Mann-Kendall test (Kendall, 1938) is commonly used for hydrologic data analysis (Hirsch and Slack, 1984; Helsel and Hirsch, 1992). However, a different or modified version of the standard test is required to evaluate water-elevation data in which a significant seasonal component exists. In response to this need, Hirsch and others (1982) developed the Seasonal Kendall Trend Test (SKTT).
The initial step in the SKTT requires that the Kendall score be computed separately for each month of the period of record. A period of 25 years, through water year 2008, was selected for this report. The separate monthly scores were summed to obtain the test statistic. The variance of the test statistic was obtained by summing the variances of the Kendall score statistic for each month. In this test, the null hypothesis is that the time series is of the form $z t=\mu m+e t$, where et is white noise error and $\mu m$ represents the mean for period $m$.

The SKTT is advantageous because it is a rank-based procedure especially suitable for non-normally distributed data, censored data, data containing outliers, and non-linear trends. The null hypothesis of randomness $H_{0}$ states that the data $\left(x_{1}, . ., x_{\mathrm{n}}\right)$ are a sample of $n$ independent and identically distributed random variables. Although the trend test statistic $Z$ is not a direct quantification of trend magnitude, it can be used as a measure of trend magnitude, or of its significance.

\section{Northwest Florida}

Groundwater data in northwest Florida are collected from two wells as part of the Climate Response Network http://groundwaterwatch.usgs.gov/ that are equipped with data recorders that measure 60 -minute interval water elevations. The daily maximum water-level elevations presented in the online annual data reports are derived from these measurements.

Water levels in the Floridan aquifer system at the USGS observation well 422A near Greenhead (303025085350501; fig. 39) remained below normal the entire water year. Daily maximum water levels at the well reached a new period of record (1963-1989 and 1998-2008) low of $44.25 \mathrm{ft}$ on January 18 and 20 . The maximum daily water level recorded was $52.30 \mathrm{ft}$ on September 5-6. Water levels in the Floridan aquifer system at the USGS benchmark well near Crawfordville (300740084293001; fig. 40) varied from below to above normal during the year. The maximum daily water level recorded was $35.04 \mathrm{ft}$ on August 25, whereas the minimum daily water level was $29.18 \mathrm{ft}$ on June 10.

\section{Northeast Florida}

Groundwater levels in northeast Florida ranged from below normal to above normal at four of the six representative sites, and below normal at the two other representative sites during the year. The USGS DOT-41 observation well at Inverness (285102082204001; fig. 41), College Street well at Leesburg (284842081533001; fig. 42), Lake Oliver deep well near Vineland (282202081384601; fig. 43), and OR-47 at Orlo Vista (283253081283401; fig. 44) all report water levels in the Upper Floridan aquifer system. Water levels in the DOT-41 well (fig. 41) were below normal the entire year (minimum water level of $23.54 \mathrm{ft}$ occurred on June 24) with a significant rise in August and continued increasing water levels to its water year maximum on September $30(27.83 \mathrm{ft})$. Water levels in the College Street well (fig. 42) varied from below normal from October to August to above normal in August and September. 


\section{EXPLANATION FOR PLOTS (FIGURES 39 TO 60) OF SUMMARY STATISTICS AND 2008 WATER YEAR DAILY MAXIMUM WATER LEVELS}

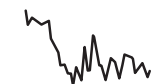

Daily maximum water level, recorded during 2008 water year

Monthly mean curve of daily maximum water levels collected
displayed, for the January 1975 to September 2008 period.
- _ - - $\quad$ One standard deviation (above or below) the monthly mean of daily maximum water levels collected, during the month displayed, for the January 1975 to September 2008 period.

\section{EXPLANATION FOR PLOTS (FIGURES 39 TO 60) OF DAILY MAXIMUM WATER LEVELS, ANNUAL MEANS OF DAILY MAXIMUM WATER LEVELS, AND RESULTS OF THE SEASONAL KENDALL TREND TEST}

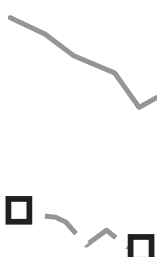

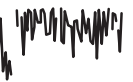

SKSE

p-value
Annual mean of daily maximum water levels collected, during the year displayed, for the October 1983 to September 2008 period, wherein no one month is missing more than 15 days of water level record

Annual mean of daily maximum water levels collected, during the year displayed, for the October 1983 to September 2008 period, wherein one or more months is missing 15 or more days of water level record.

Daily maximum water level. Breaks in line represent missing measurements, or measurements that failed quality assurance review.

The Seasonal Kendall Slope Estimator (SKSE) represents the median slope of the set of slopes obtained by computing the slope, in feet per year, of all unique pairs of monthly mean daily maximum water levels computed for the site shown.

The $p$-value represents a measure of the significance level of the Seasonal Kendall Trend Test statistic, computed concurrently with the SKSE, used to determine if there is a trend in the data examined. A p-value less than 0.05 indicates a statistically significant trend. 


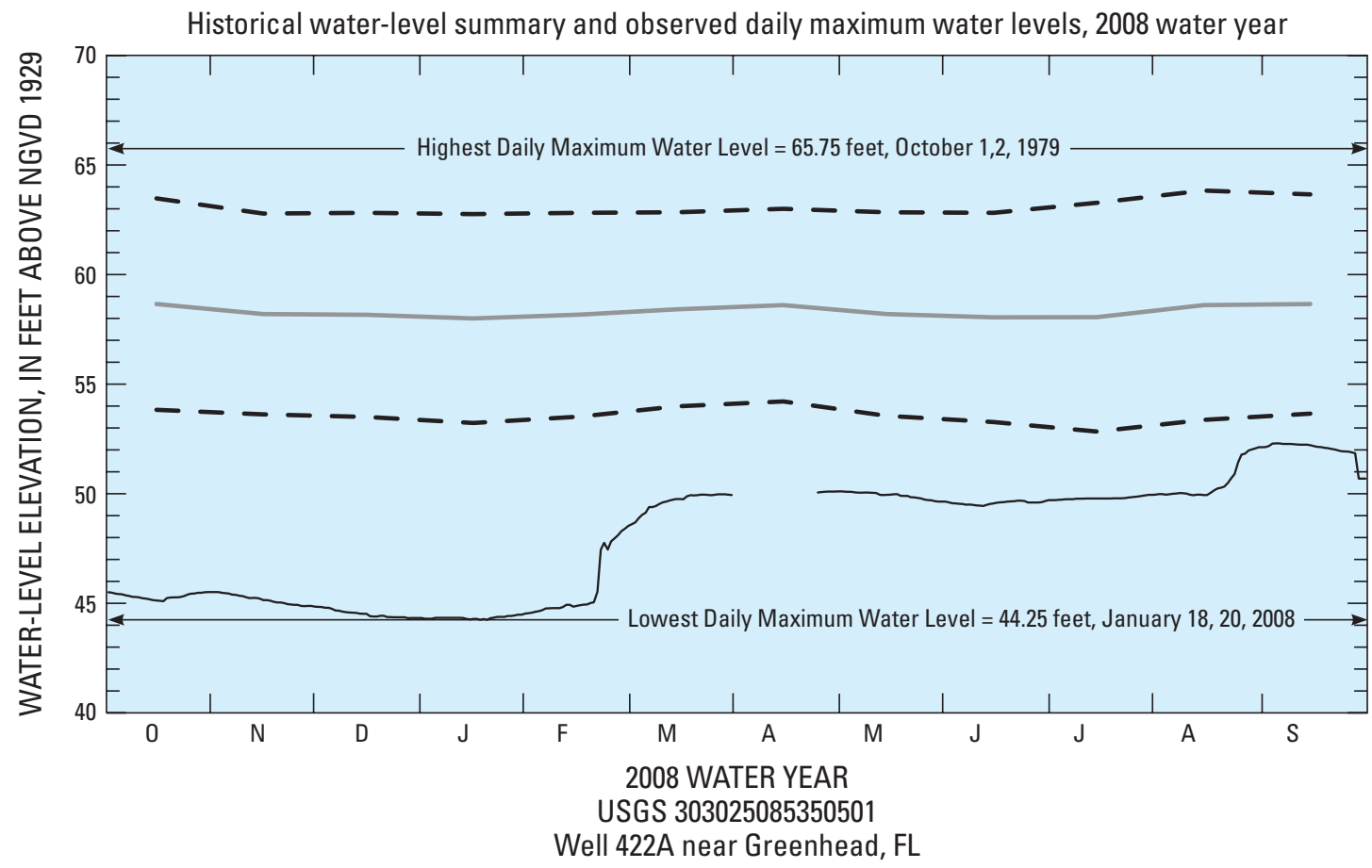

Historical daily maximum water levels, annual means of daily maximum water levels, and results of Seasonal Kendall Trend Test

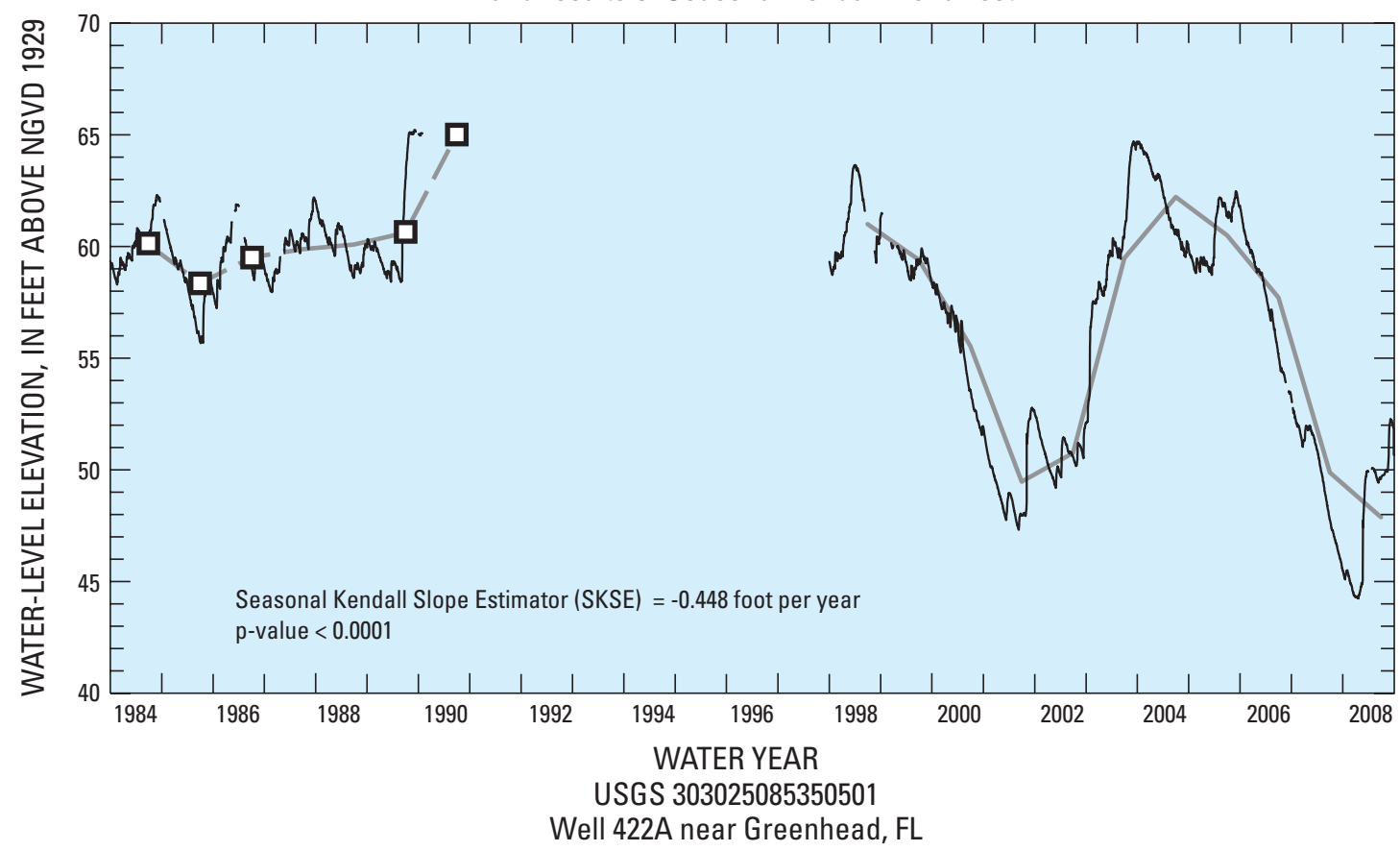

Figure 39. USGS observation well 422A near Greenhead water year 2008 daily maximum water level compared to historical water levels for the period October 1983 to September 2008, and the Seasonal Kendall Trend Test for the period October 1983 to September 2008. 


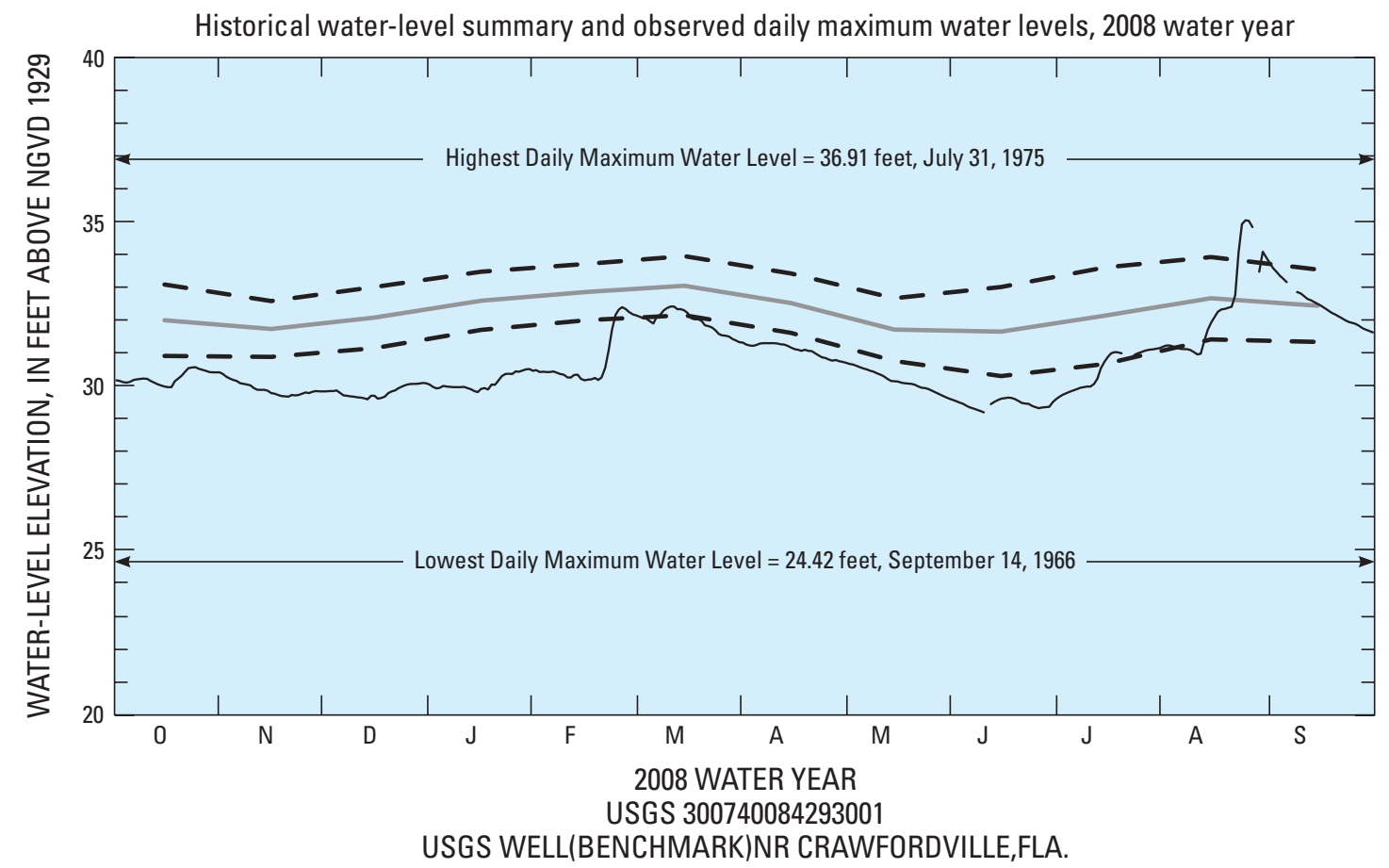

Historical daily maximum water levels, annual means of daily maximum water levels, and results of Seasonal Kendall Trend Test

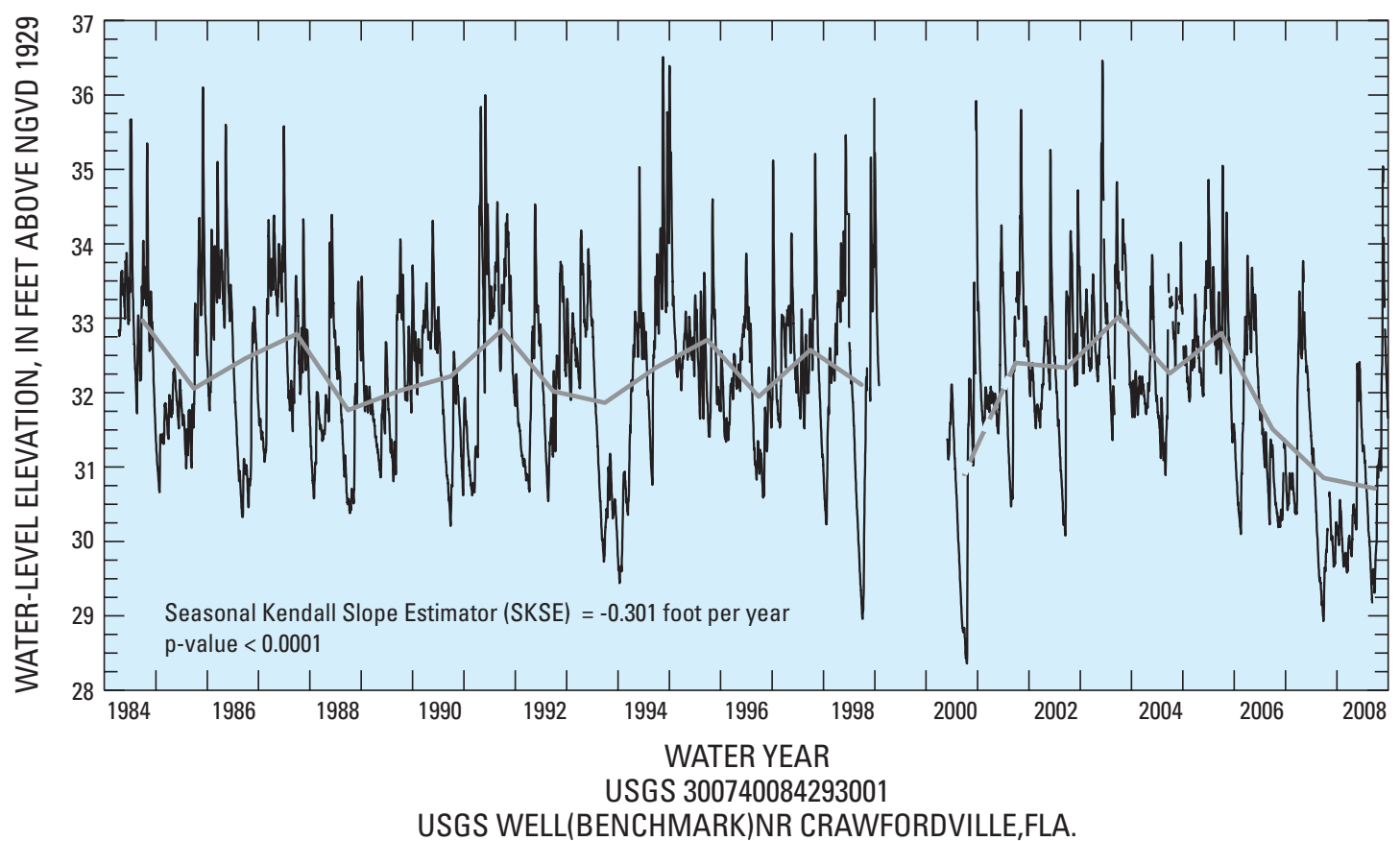

Figure 40. USGS benchmark well near Crawfordville water year 2008 daily maximum water level compared to historical water levels for the period October 1983 to September 2008, and the Seasonal Kendall Trend Test for the period October 1983 to September 2008. 


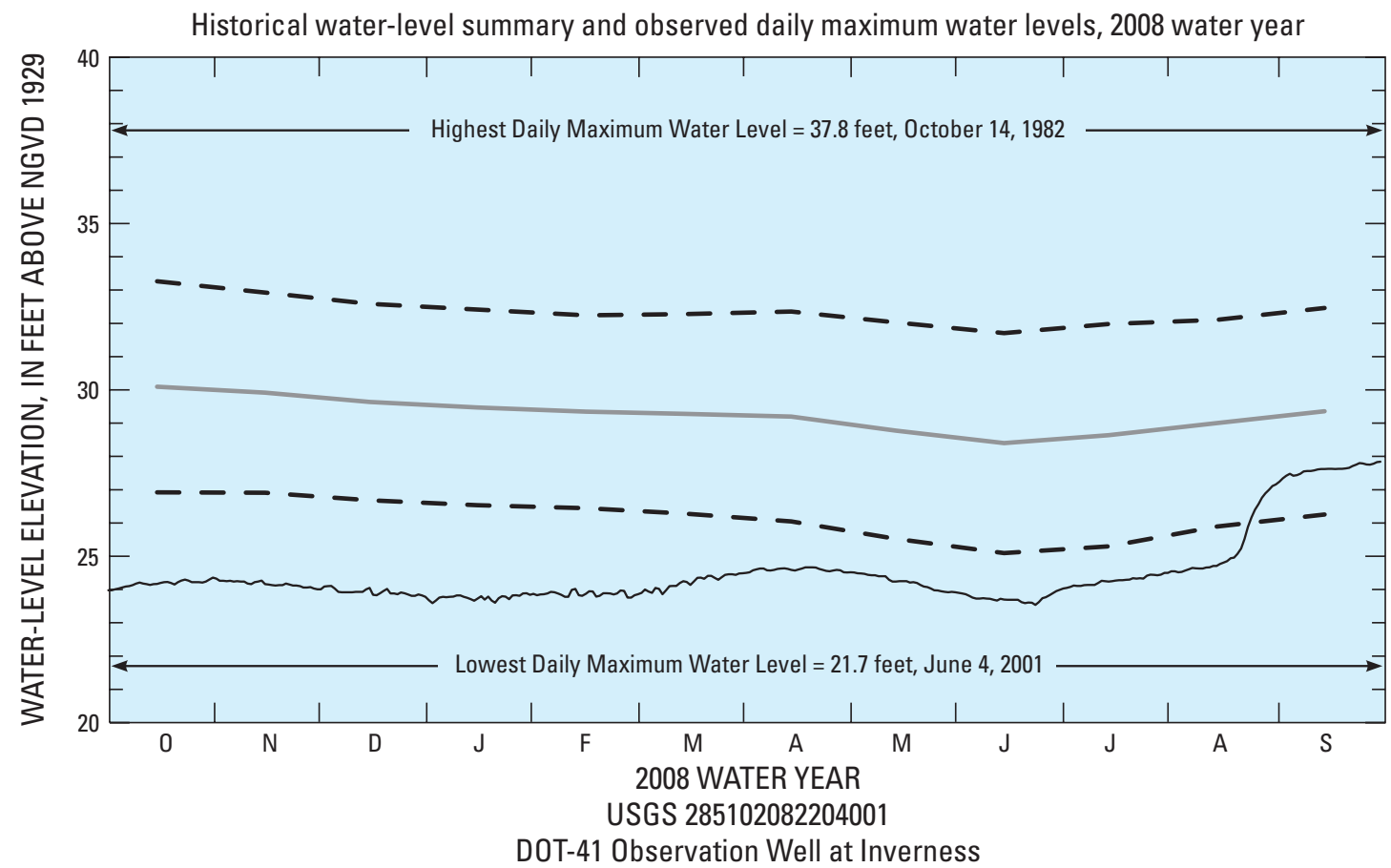

Historical daily maximum water levels, annual means of daily maximum water levels, and results of Seasonal Kendall Trend Test

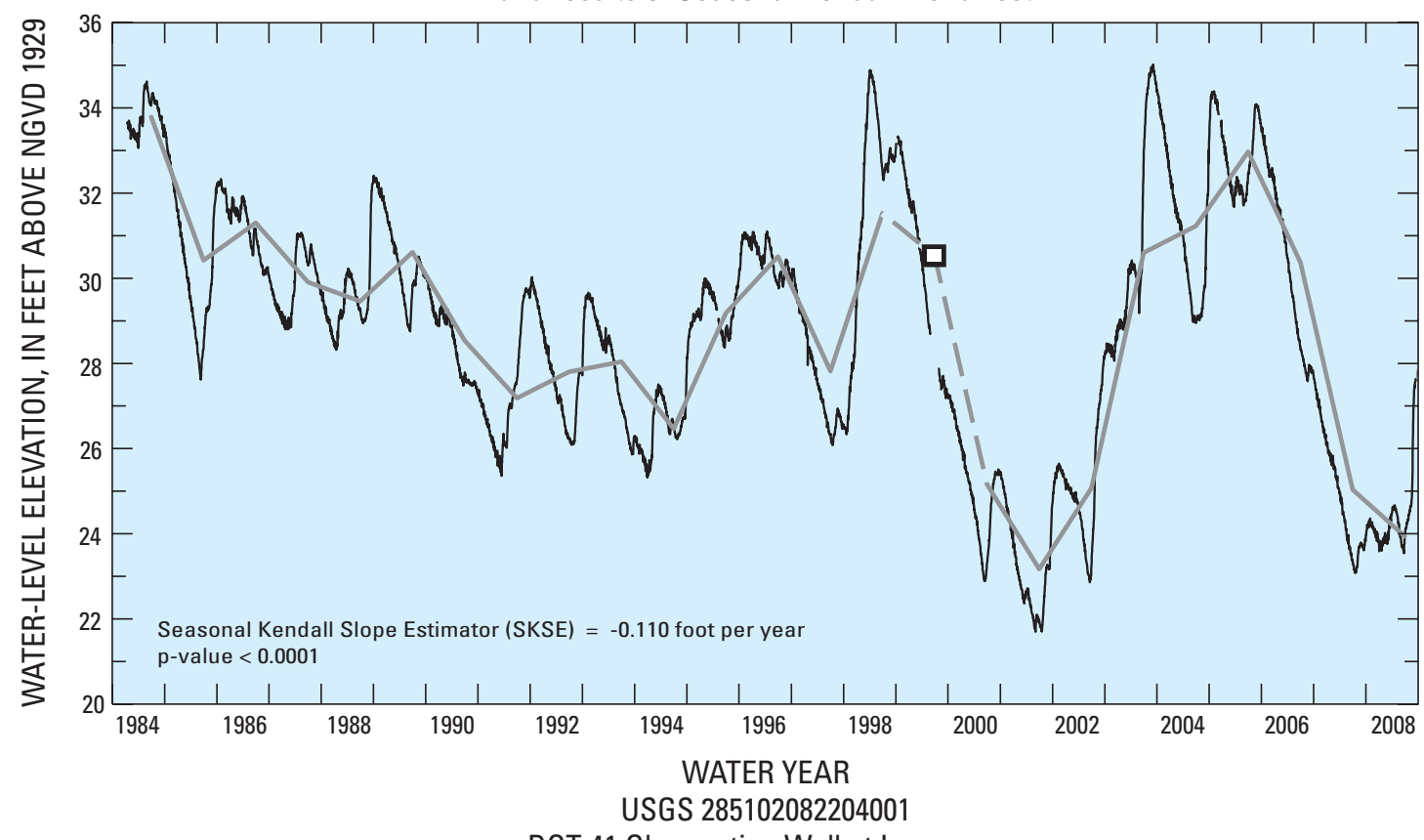

DOT-41 Observation Well at Inverness

Figure 41. DOT-41 observation well at Inverness water year 2008 daily maximum water level compared to historical water levels for the period October 1983 to September 2008, and the Seasonal Kendall Trend Test for the period October 1983 to September 2008. 


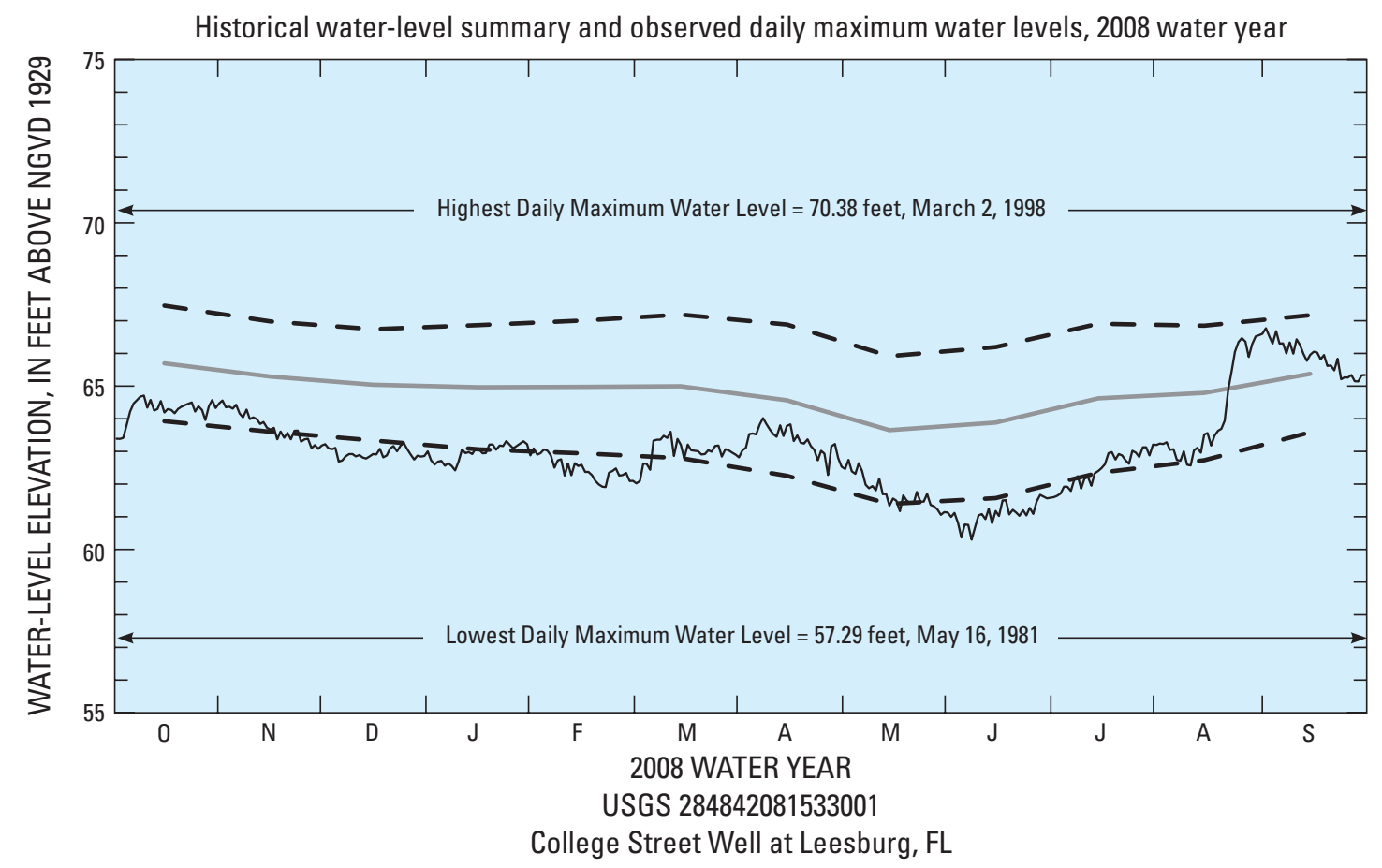

Historical daily maximum water levels, annual means of daily maximum water levels, and results of Seasonal Kendall Trend Test

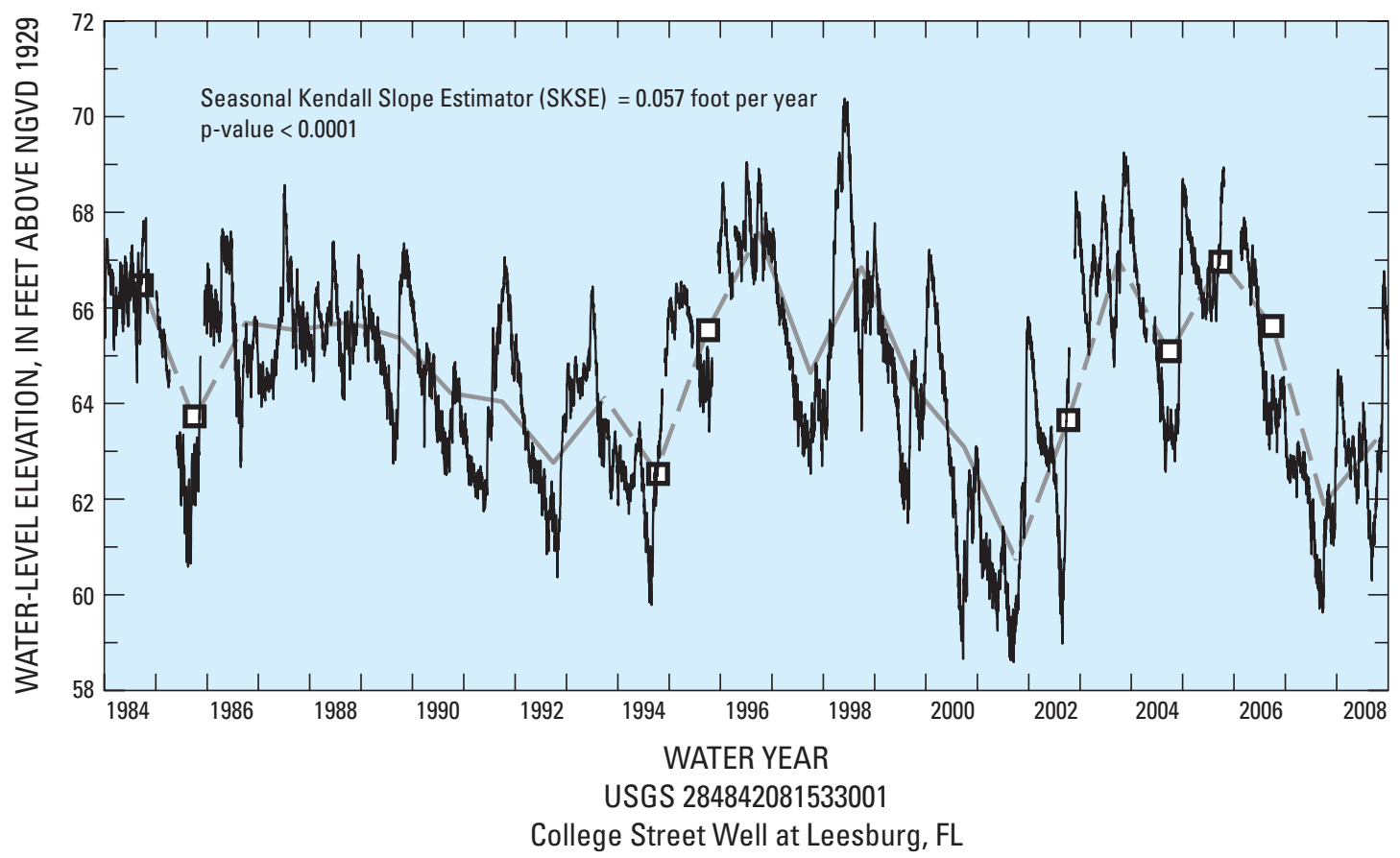

Figure 42. College Street well at Leesburg water year 2008 daily maximum water level compared to historical water levels for the period October 1983 to September 2008, and the Seasonal Kendall Trend Test for the period October 1983 to September 2008. 
Historical water-level summary and observed daily maximum water levels, 2008 water year

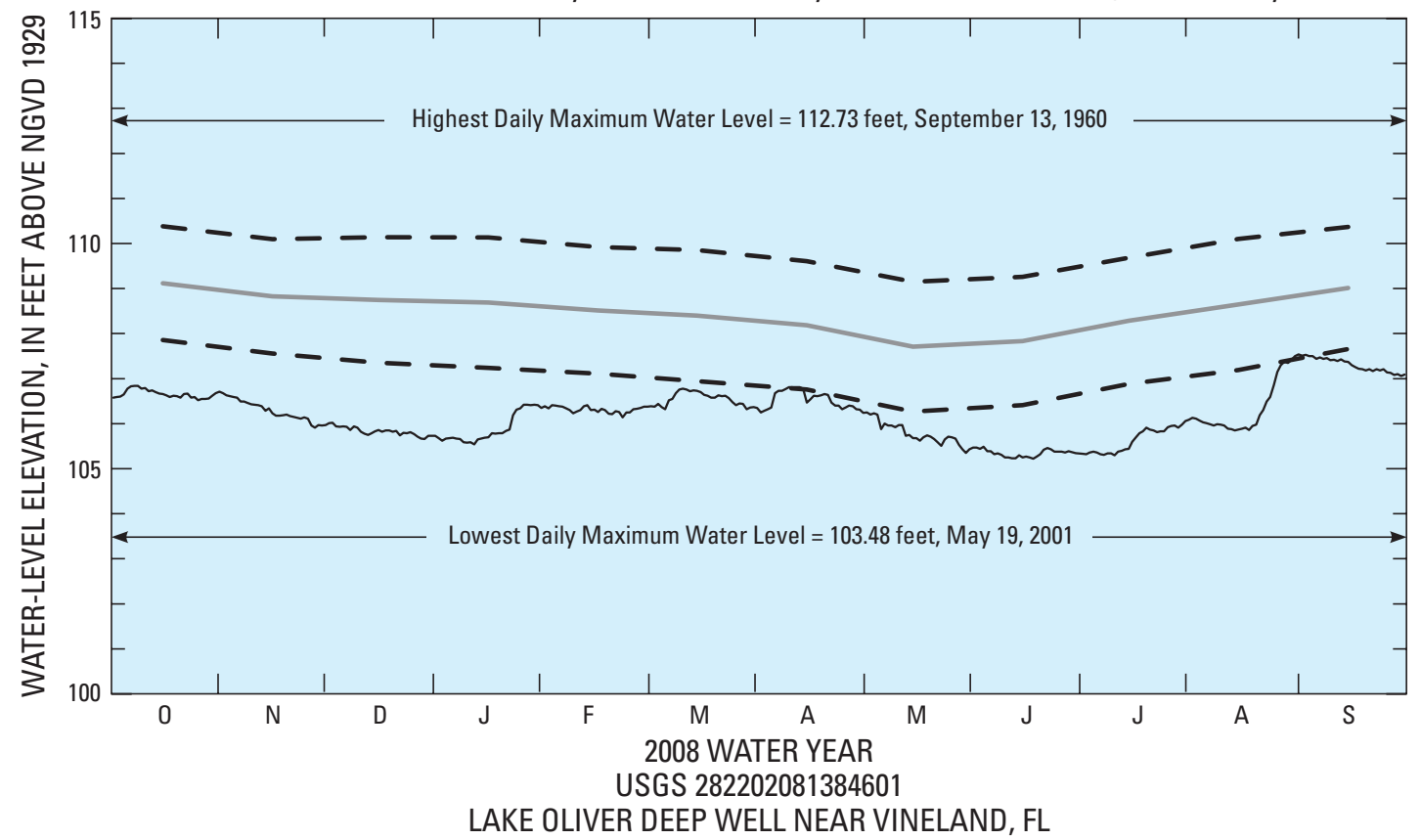

Historical daily maximum water levels, annual means of daily maximum water levels, and results of Seasonal Kendall Trend Test

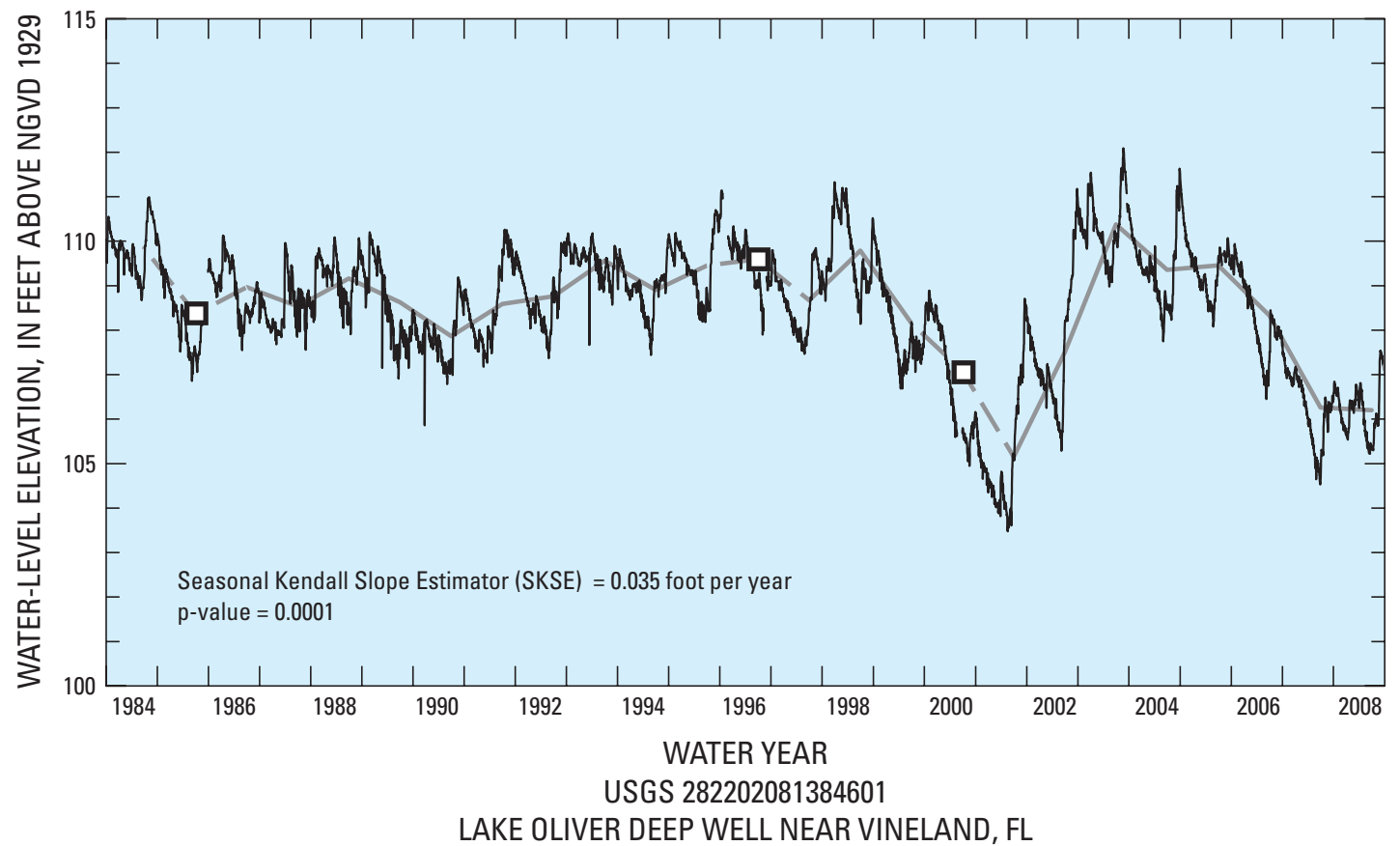

Figure 43. Lake Oliver deep well near Vineland water year 2008 daily maximum water level compared to historical water levels for the period October 1983 to September 2008, and the Seasonal Kendall Trend Test for the period October 1983 to September 2008. 


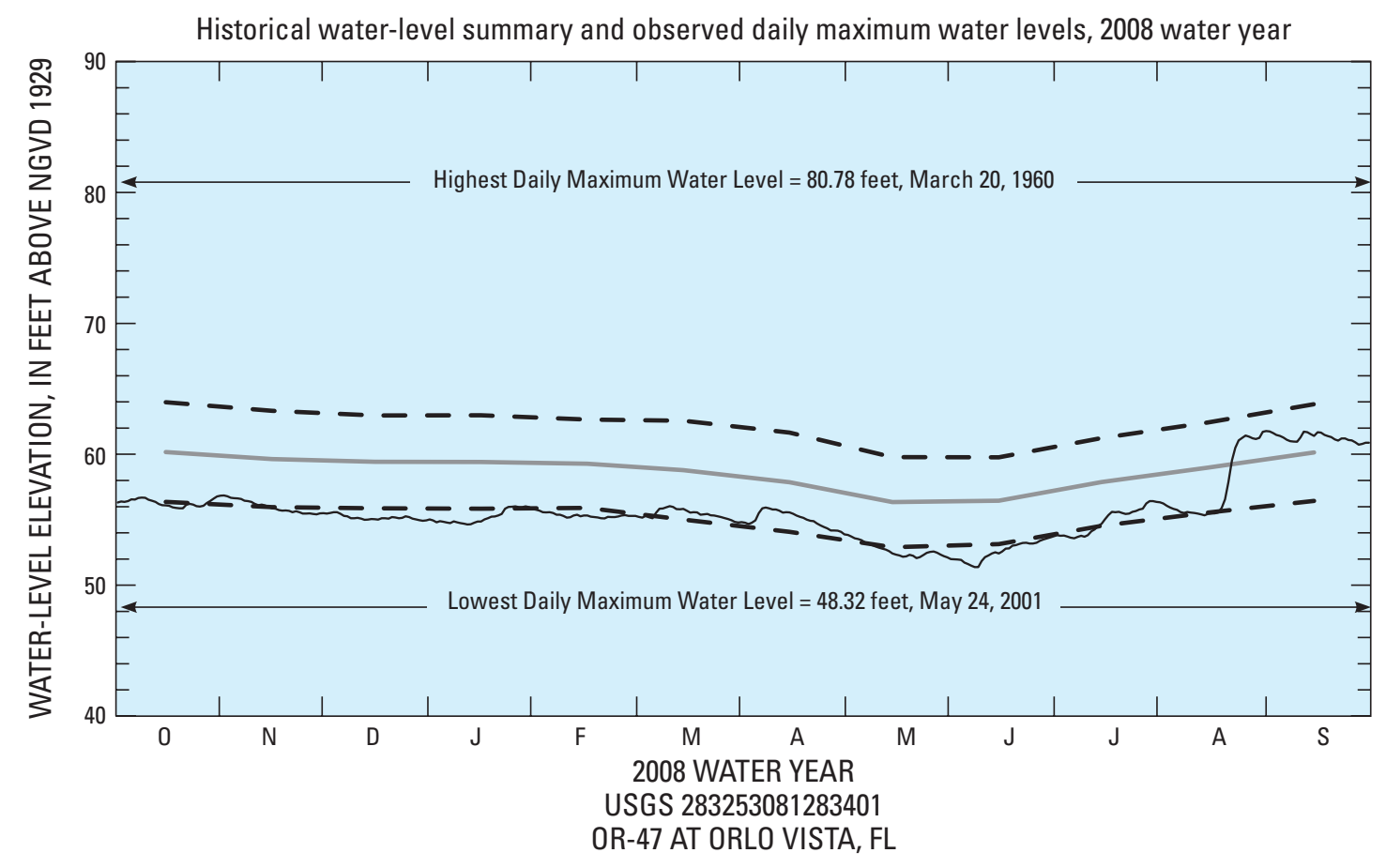

Historical daily maximum water levels, annual means of daily maximum water levels, and results of Seasonal Kendall Trend Test

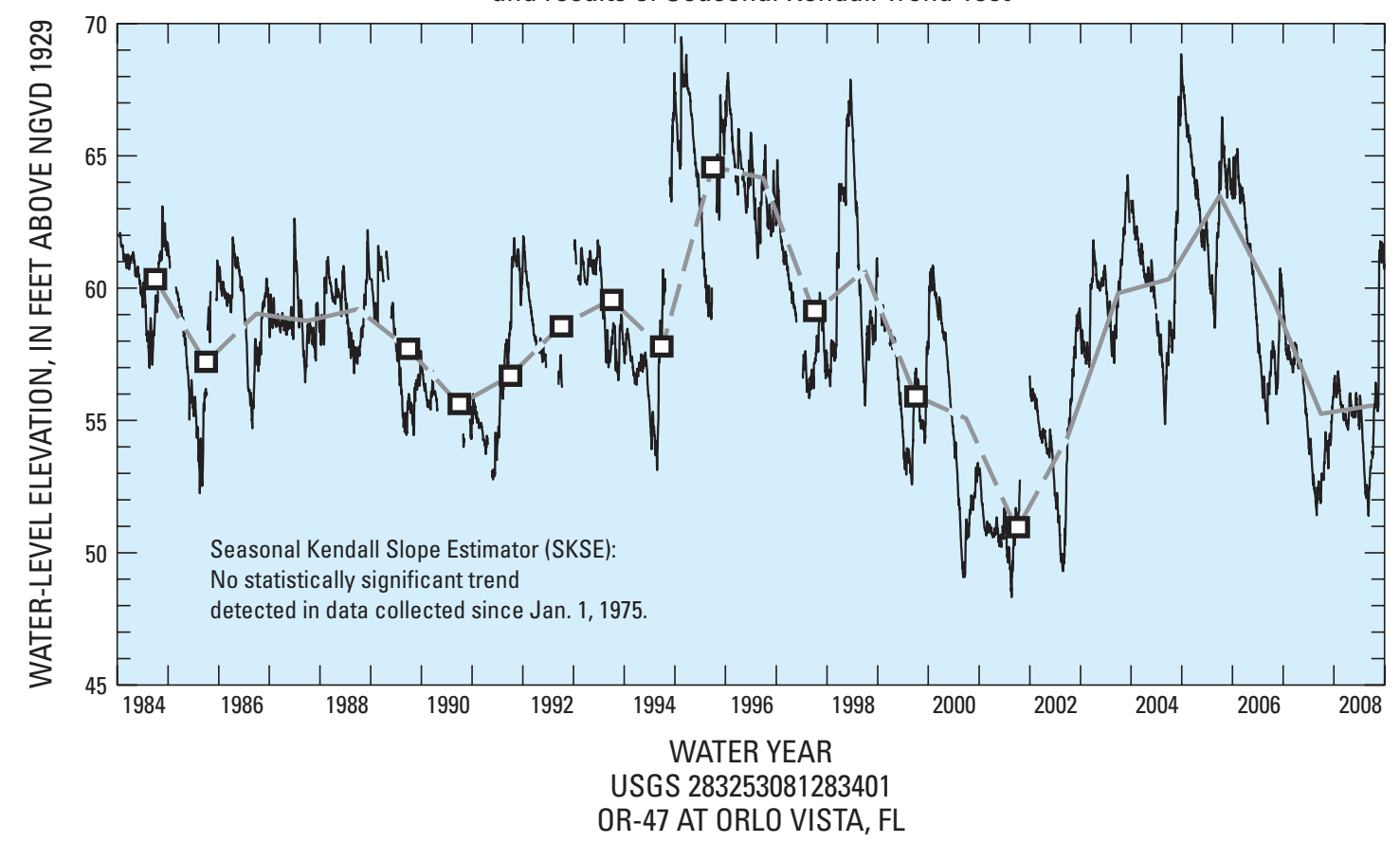

Figure 44. $\quad$ OR-47 at Orlo Vista water year 2008 daily maximum water level compared to historical water levels for the period October 1983 to September 2008, and the Seasonal Kendall Trend Test for the period October 1983 to September 2008. 


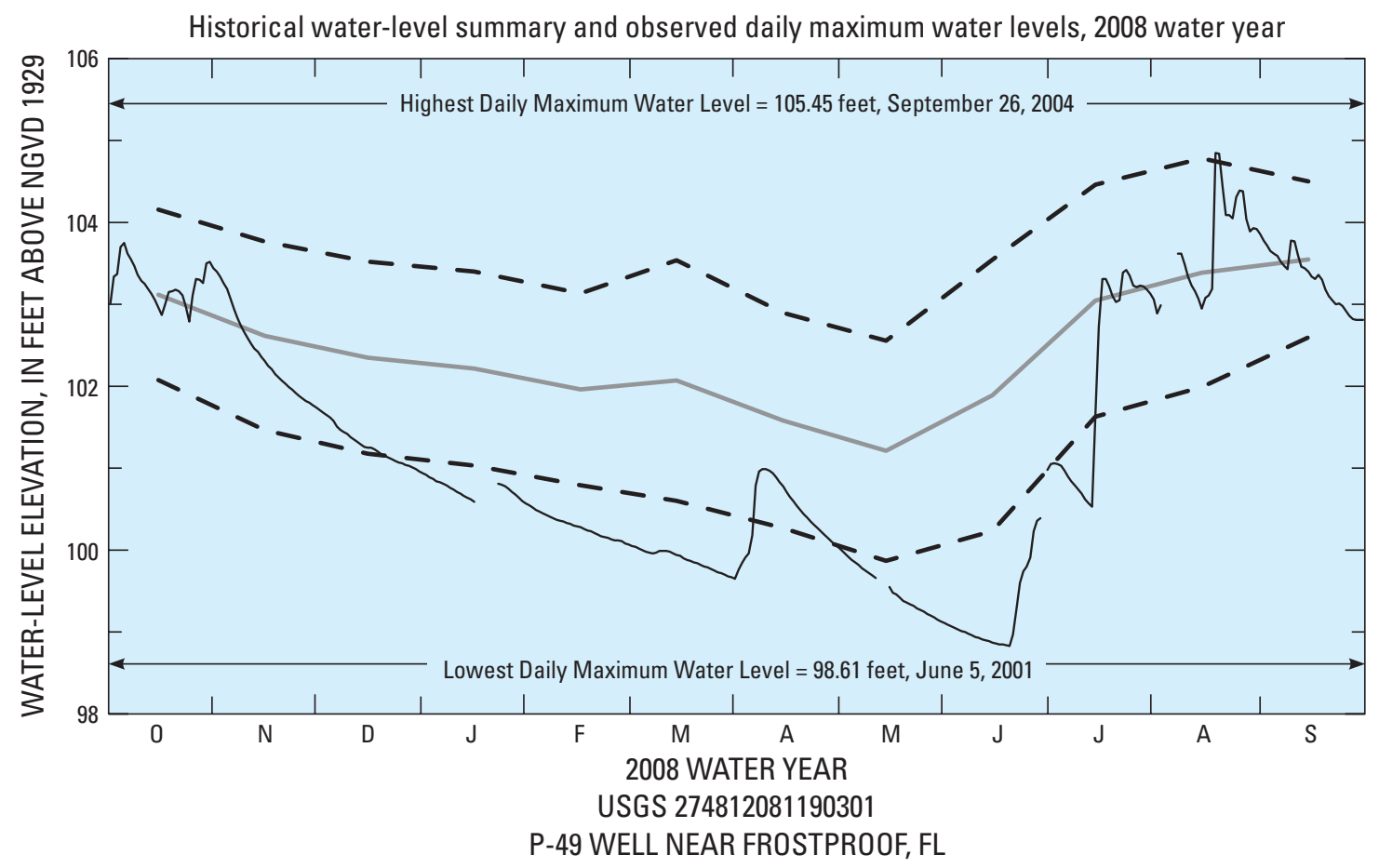

Historical daily maximum water levels, annual means of daily maximum water levels, and results of Seasonal Kendall Trend Test

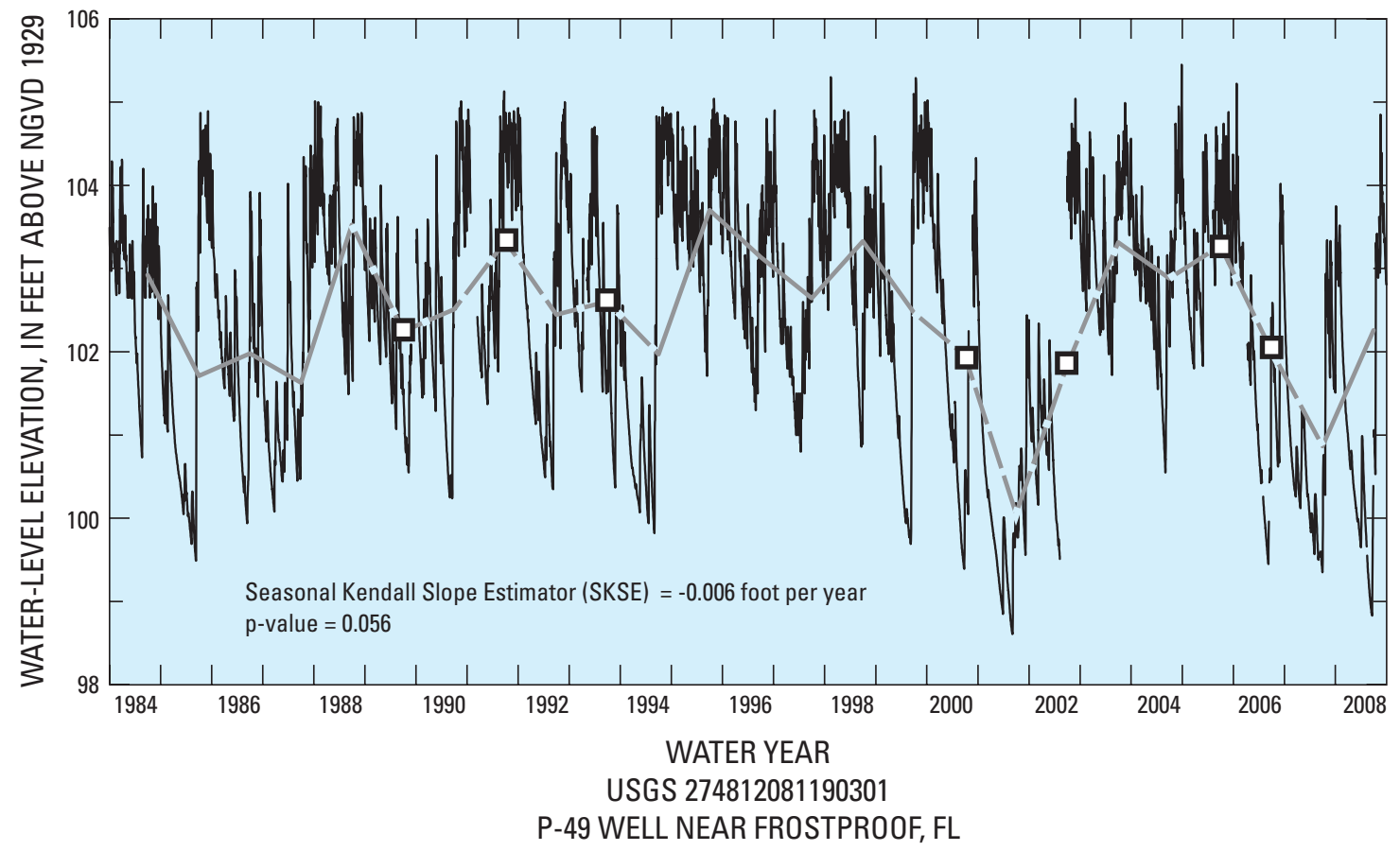

Figure 45. P-49 well near Frostproof water year 2008 daily maximum water level compared to historical water levels for the period October 1983 to September 2008, and the Seasonal Kendall Trend Test for the period October 1983 to September 2008. 

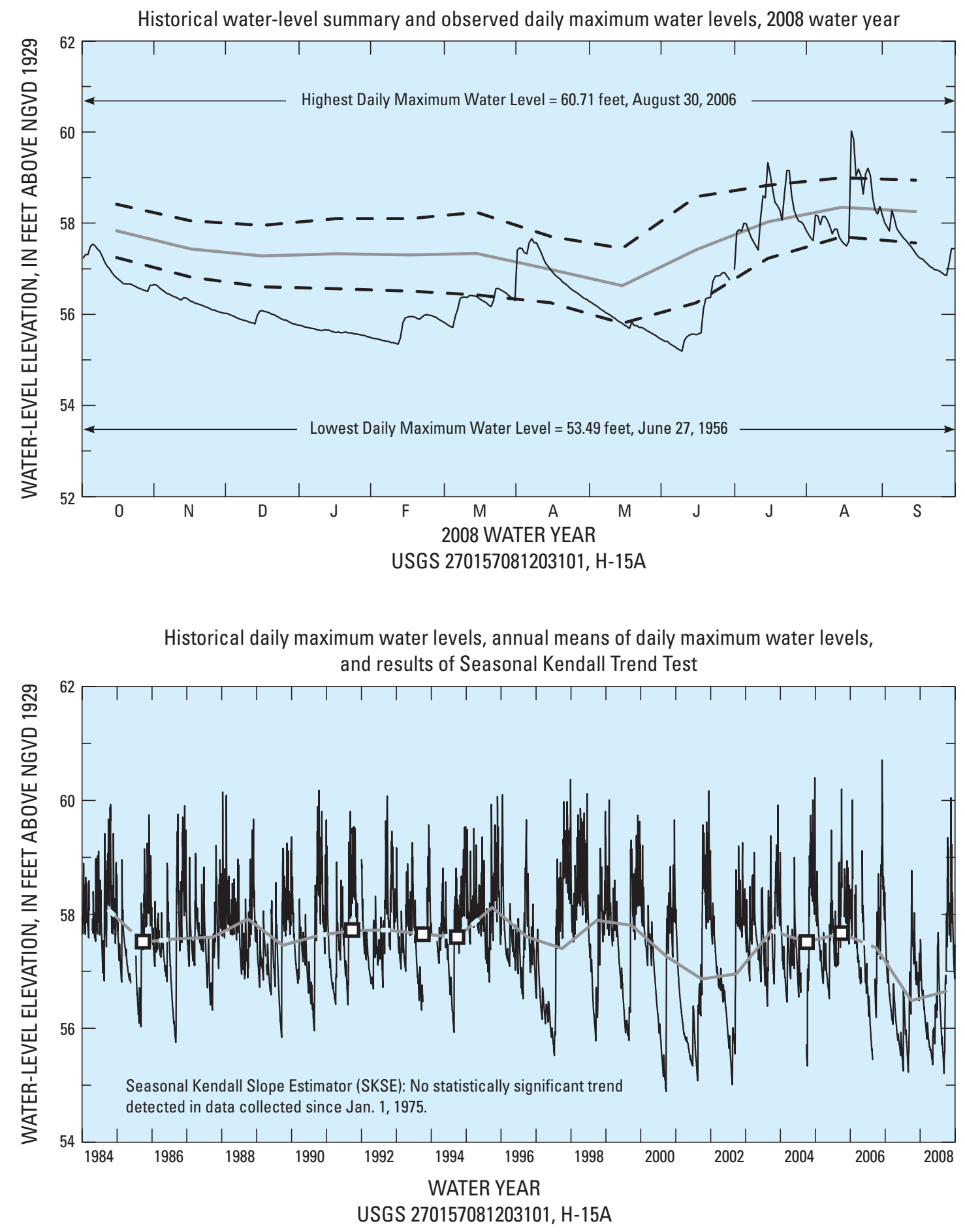

Figure 46. USGS observation well H-15A near Palmdale water year 2008 daily maximum water level compared to historical water levels for the period October 1983 to September 2008, and the Seasonal Kendall Trend Test for the period October 1983 to September 2008. 


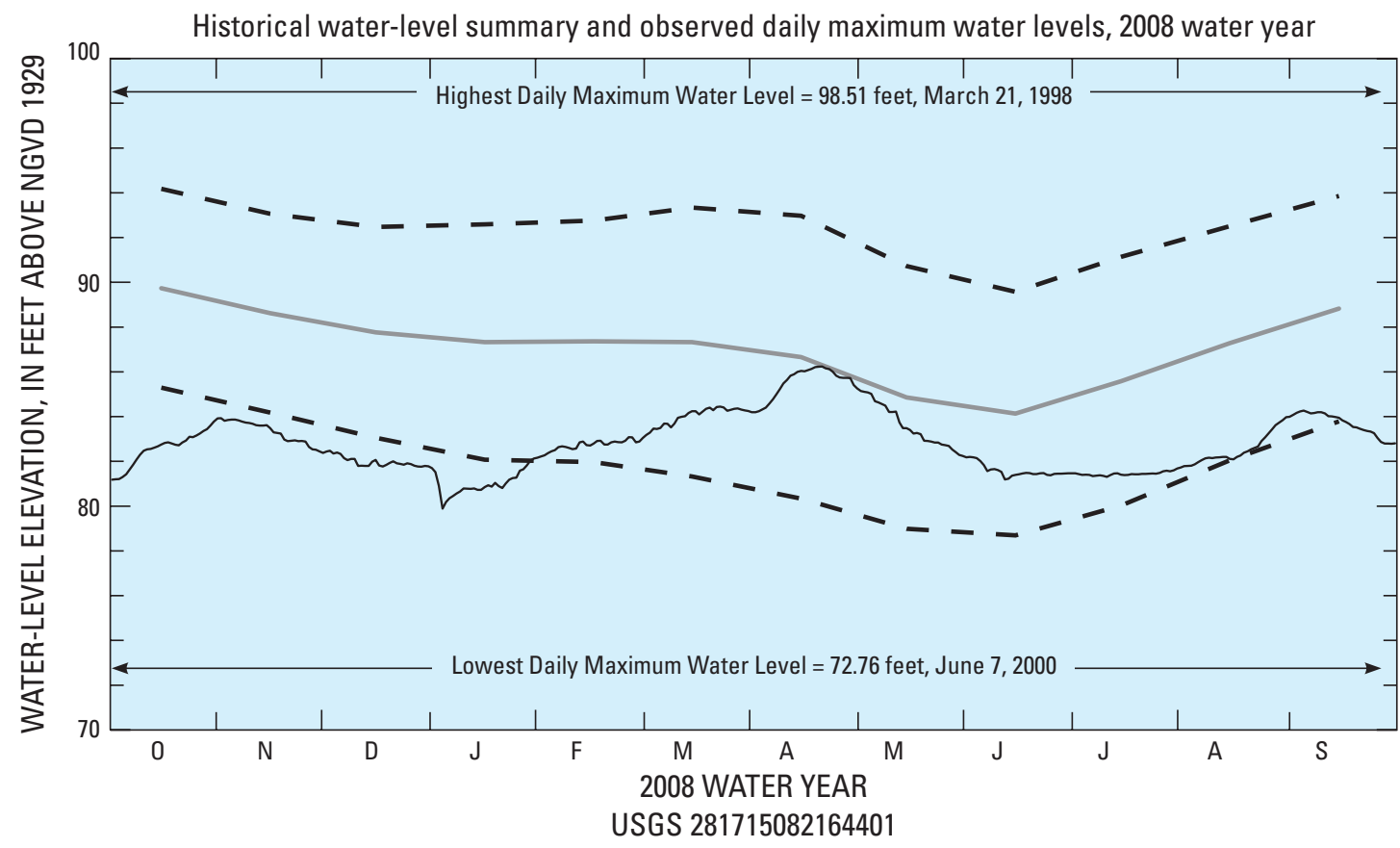

State Highway 577 Well near San Antonio, FL

Historical daily maximum water levels, annual means of daily maximum water levels, and results of Seasonal Kendall Trend Test

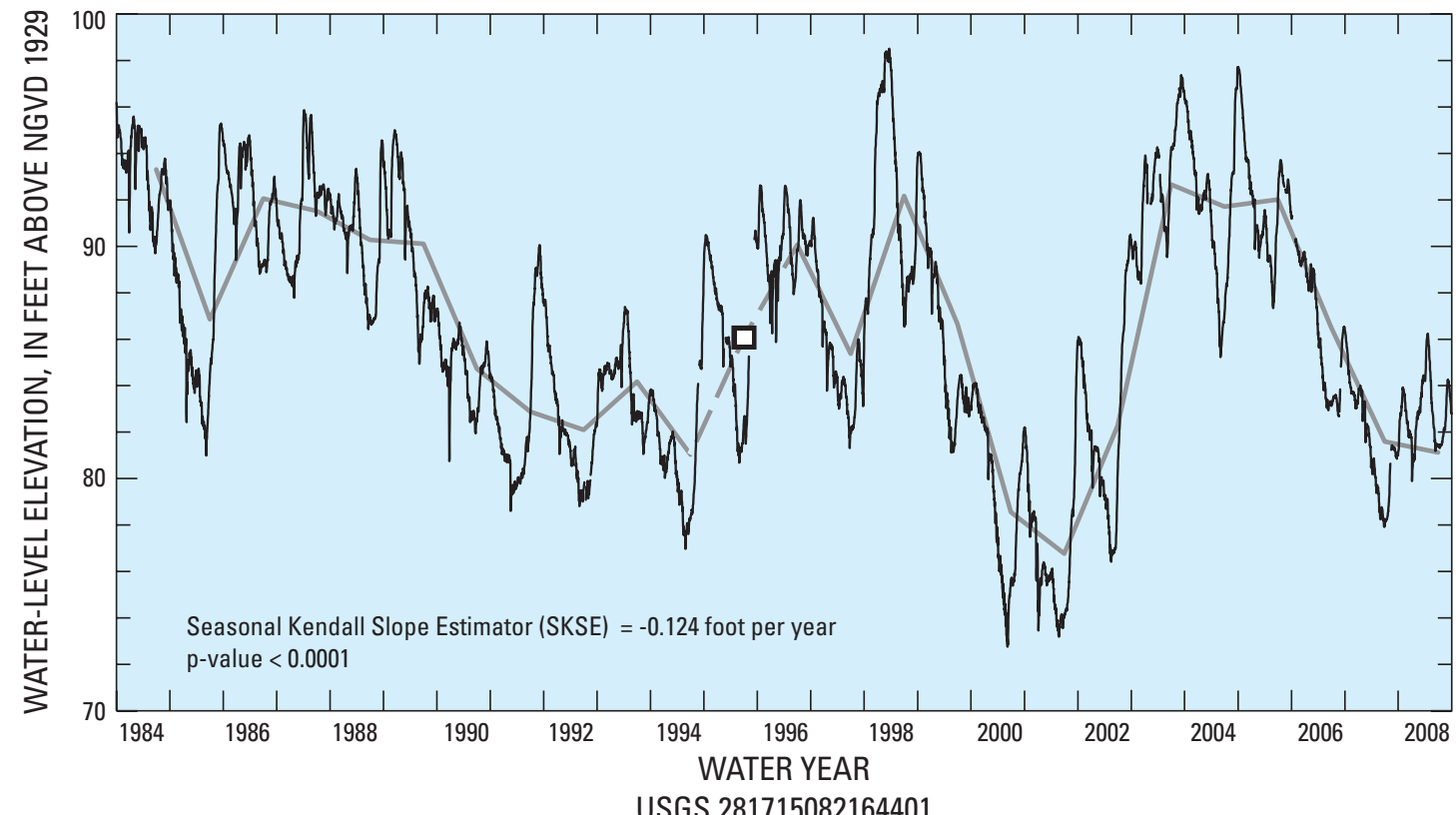

USGS 281715082164401

State Highway 577 Well near San Antonio, FL

Figure 47. State Highway 577 well near San Antonio water year 2008 daily maximum water level compared to historical water levels for the period October 1983 to September 2008, and the Seasonal Kendall Trend Test for the period October 1983 to September 2008. 


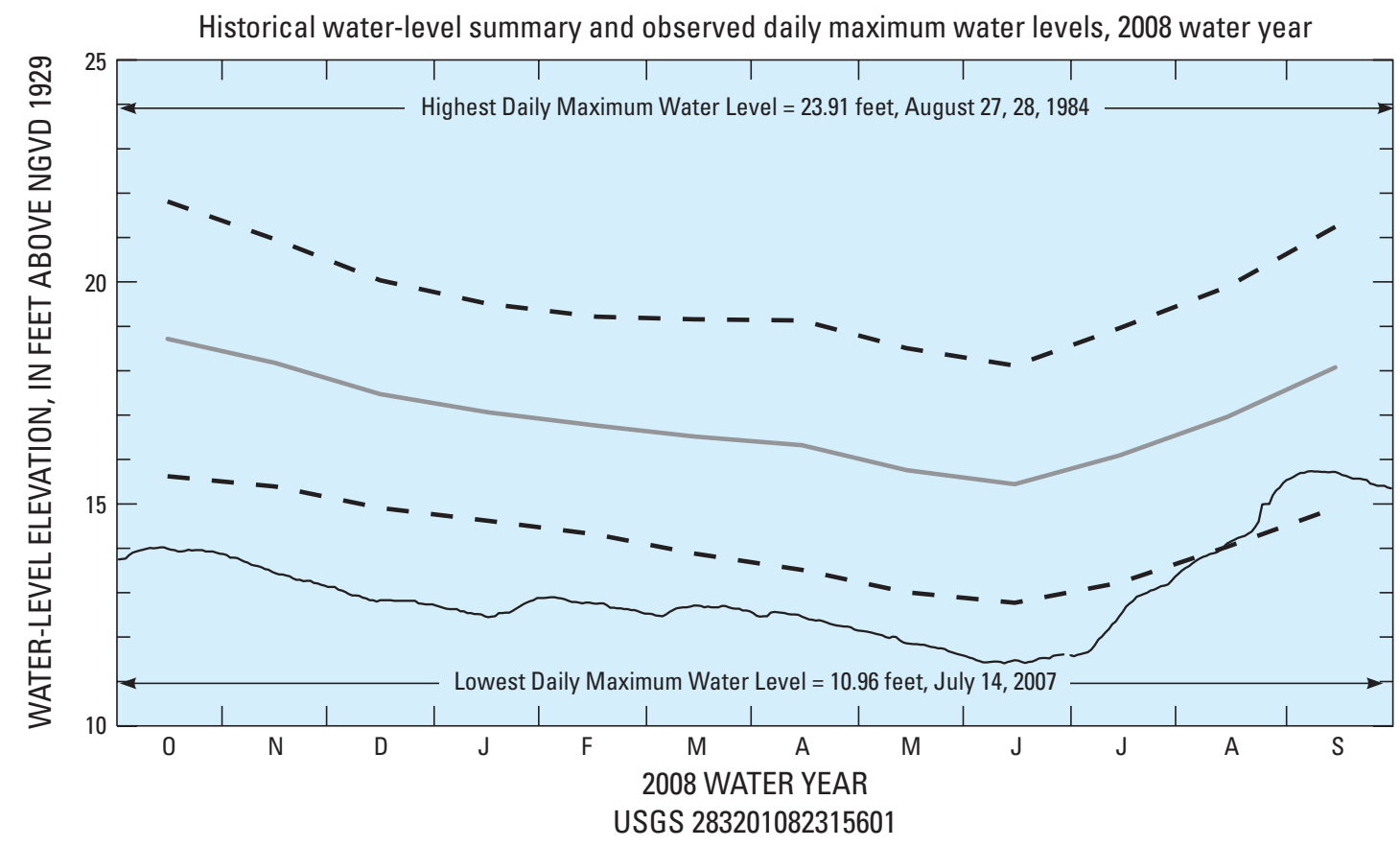

Weeki Wachee Well near Weeki Wachee, FL

Historical daily maximum water levels, annual means of daily maximum water levels, and results of Seasonal Kendall Trend Test

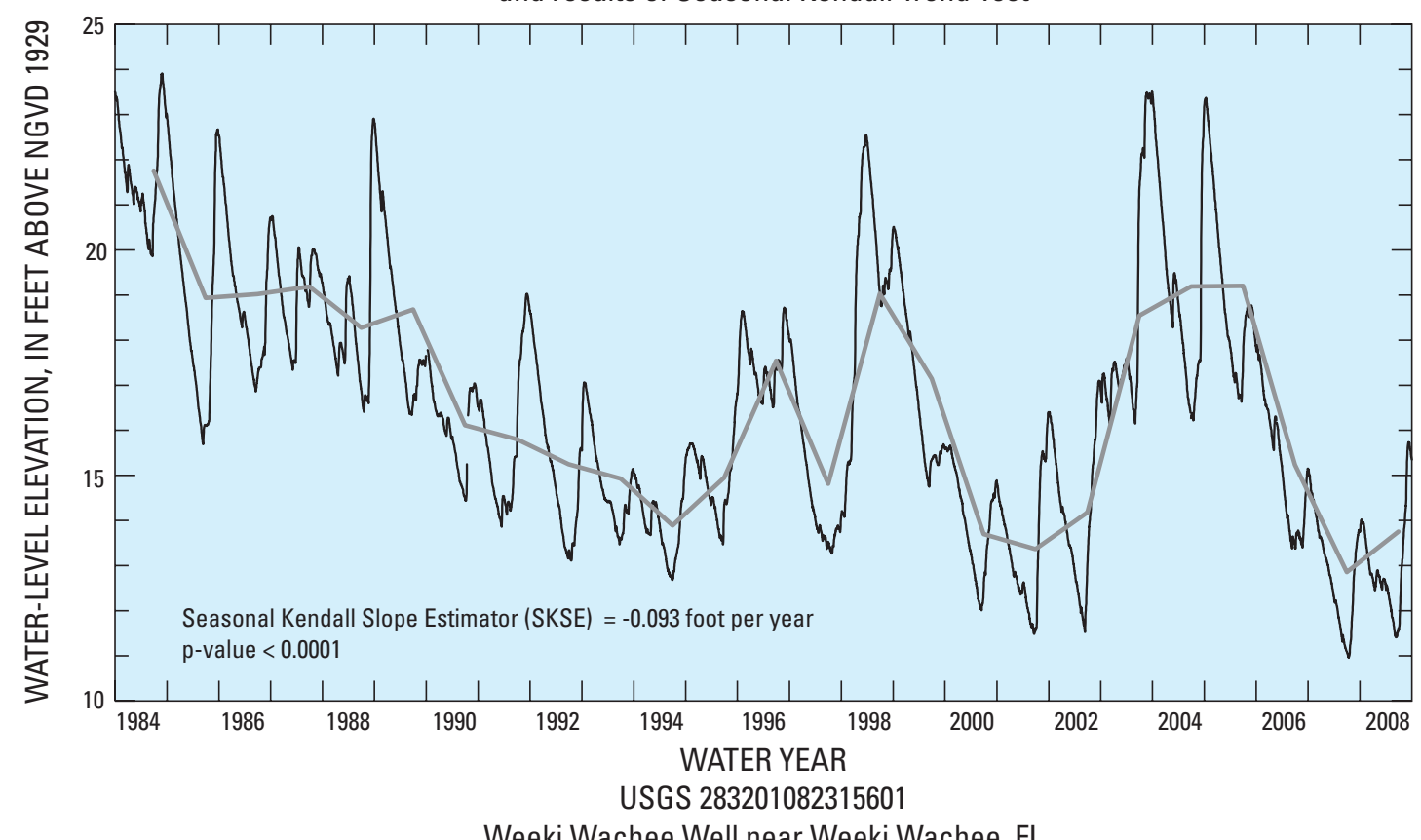

Weeki Wachee Well near Weeki Wachee, FL

Figure 48. Weeki Wachee well near Weeki Wachee water year 2008 daily maximum water level compared to historical water levels for the period October 1983 to September 2008, and the Seasonal Kendall Trend Test for the period October 1983 to September 2008. 


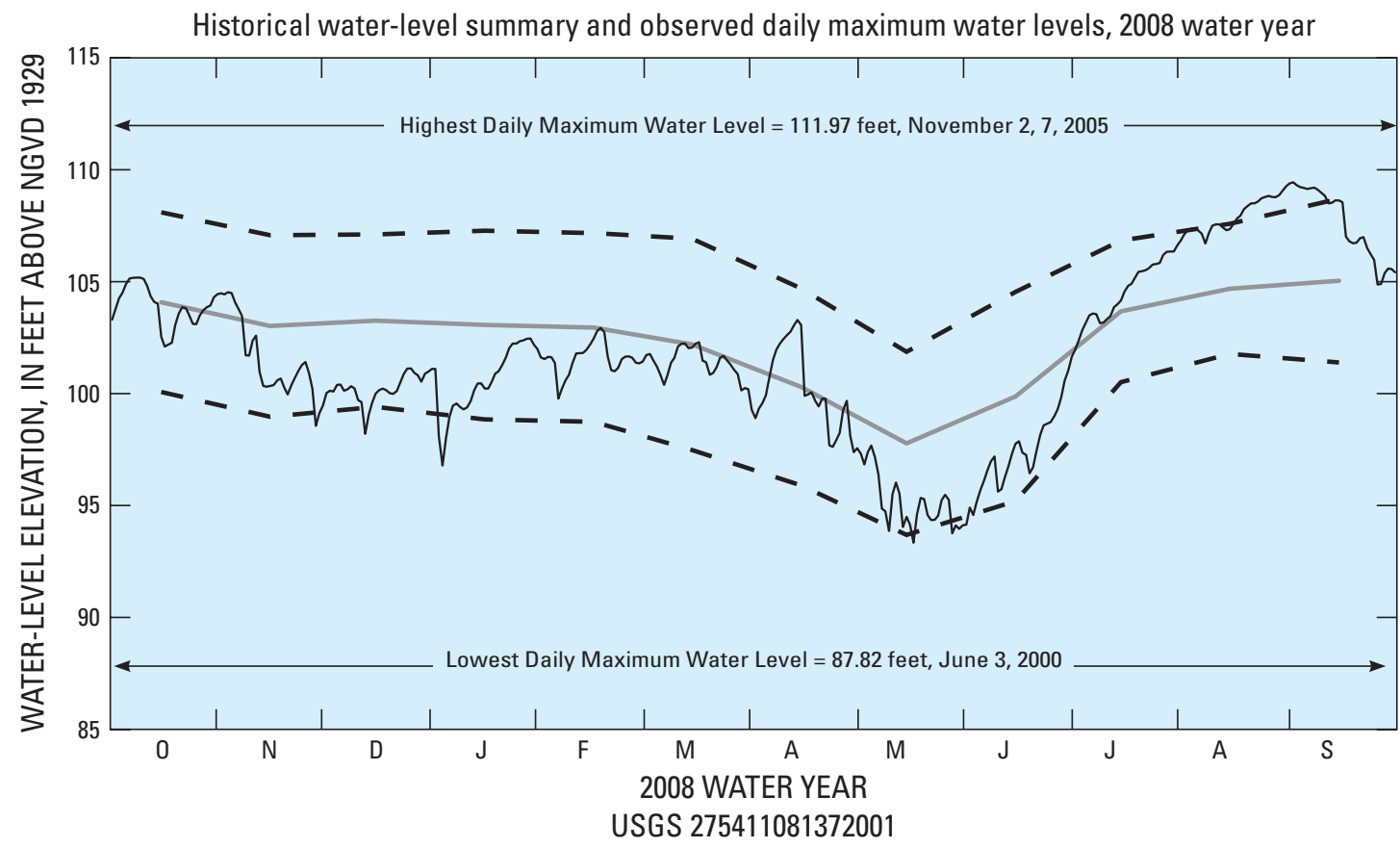

ROMP 57 Floridan Well near Lake Wales, FL

Historical daily maximum water levels, annual means of daily maximum water levels, and results of Seasonal Kendall Trend Test

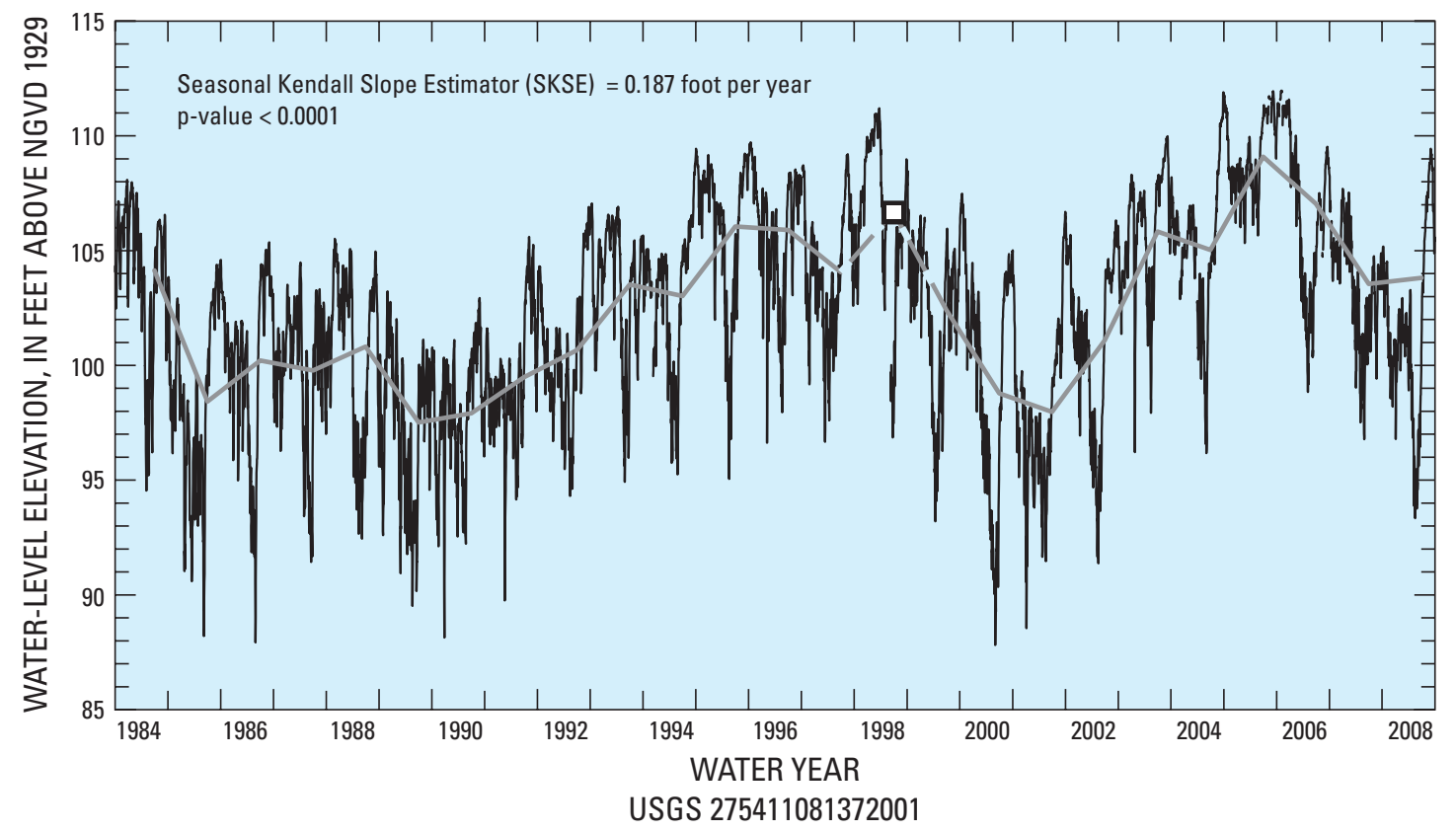

ROMP 57 Floridan Well near Lake Wales, FL

Figure 49. ROMP 57 Floridan well near Lake Wales water year 2008 daily maximum water level compared to historical water levels for the period October 1983 to September 2008, and the Seasonal Kendall Trend Test for the period October 1983 to September 2008. 


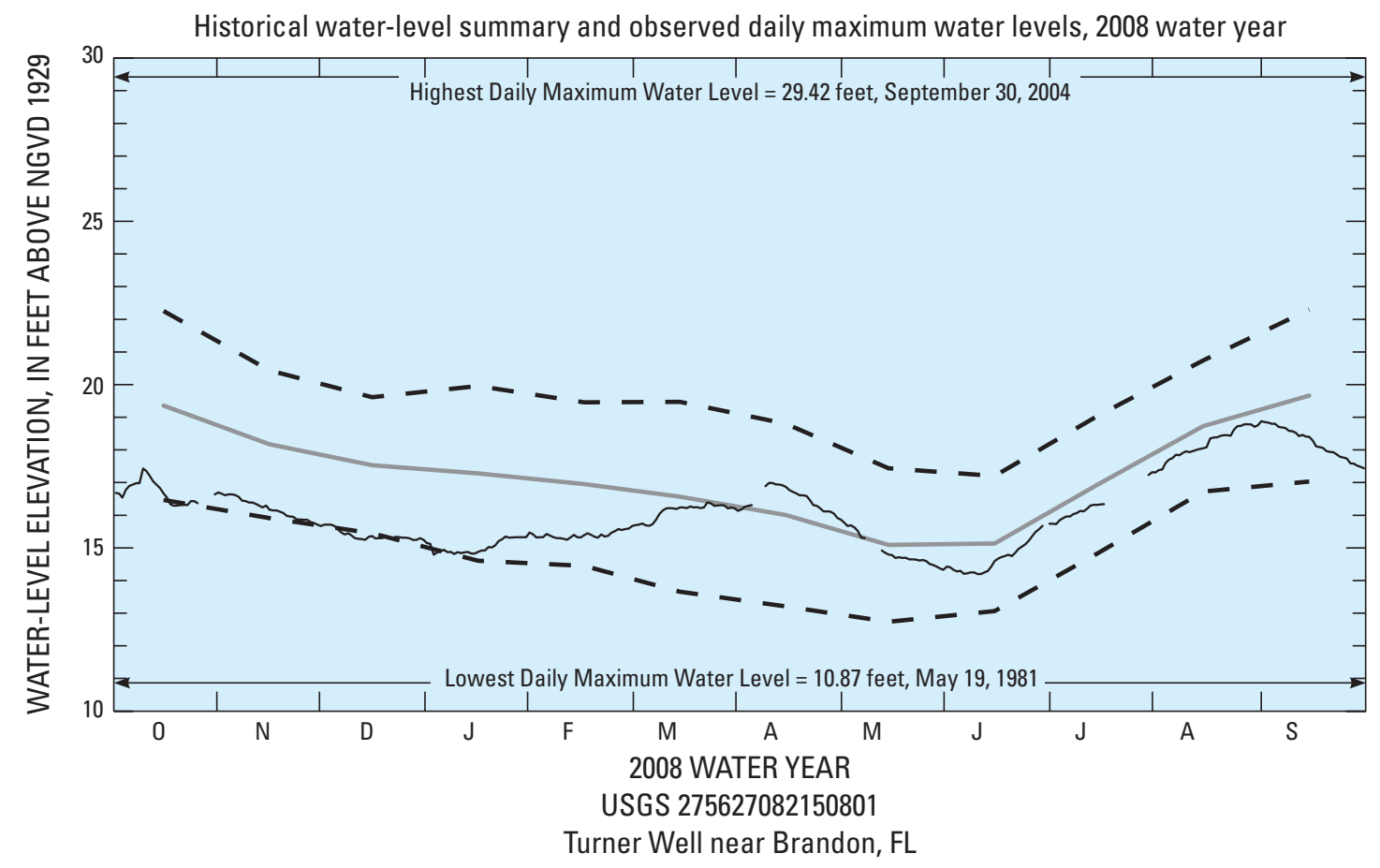

Historical daily maximum water levels, annual means of daily maximum water levels, and results of Seasonal Kendall Trend Test

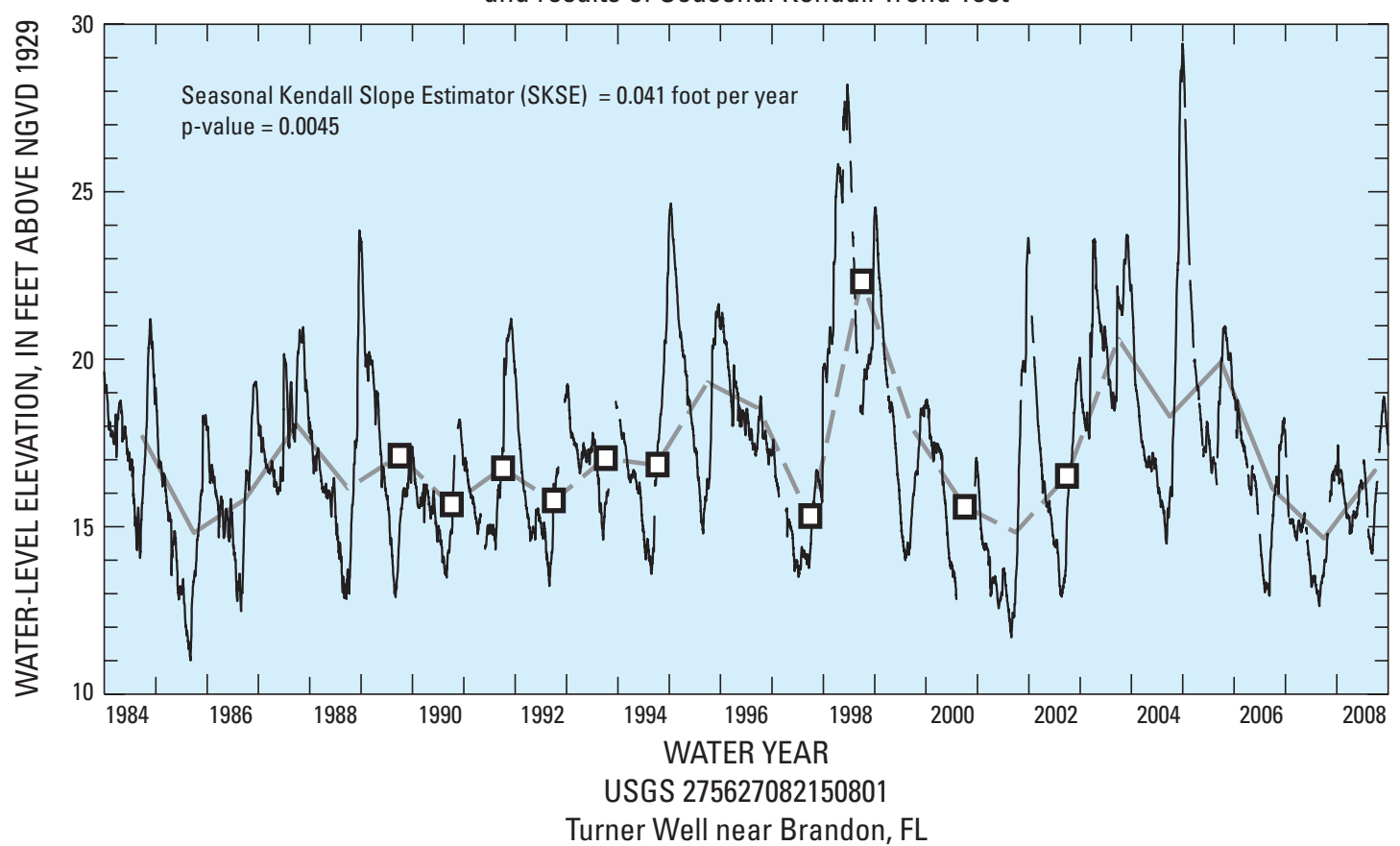

Figure 50. Turner well near Brandon water year 2008 daily maximum water level compared to historical water levels for the period October 1983 to September 2008, and the Seasonal Kendall Trend Test for the period October 1983 to September 2008. 


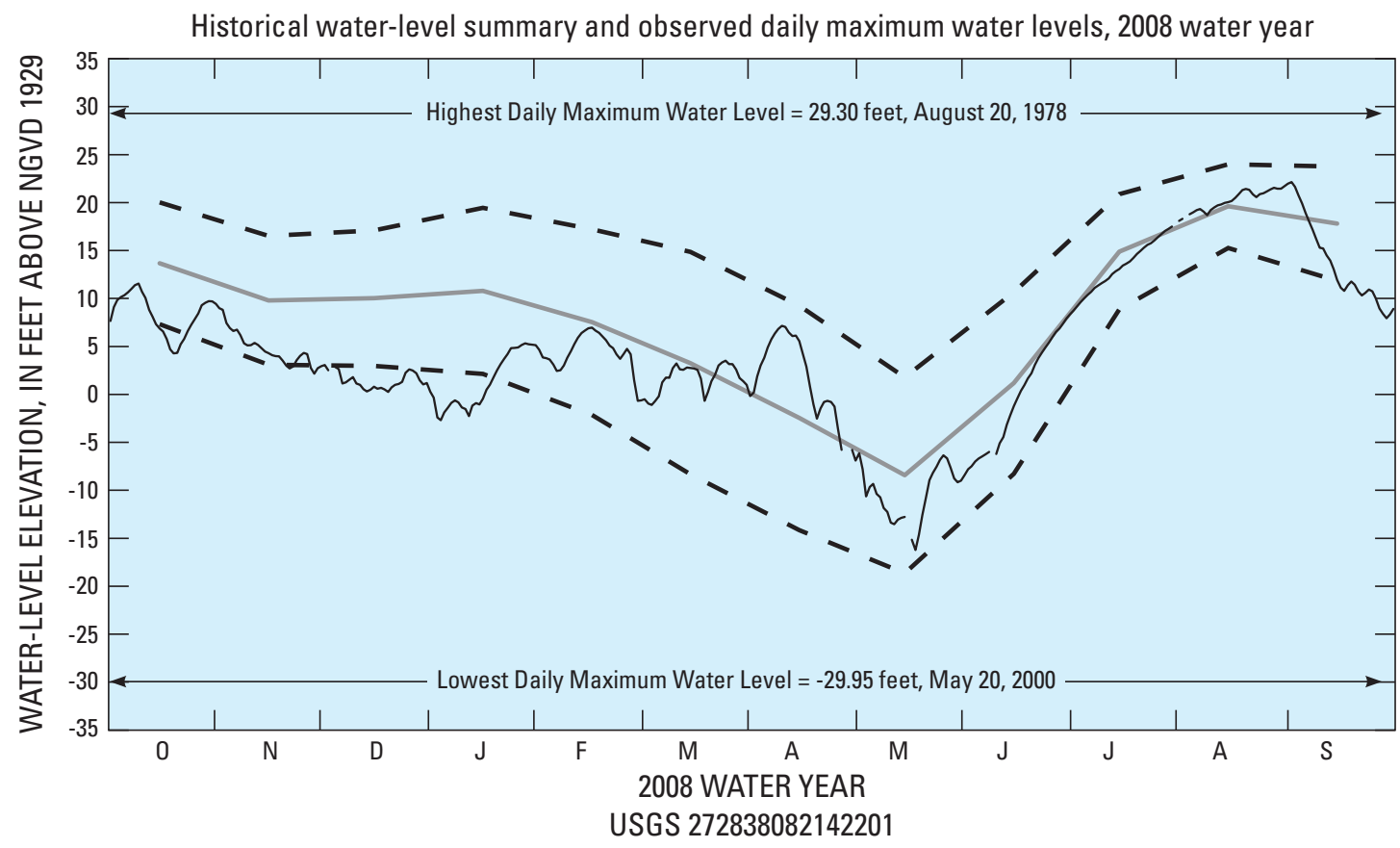

Kibler Deep Well 26B near Bethany, FL

Historical daily maximum water levels, annual means of daily maximum water levels, and results of Seasonal Kendall Trend Test

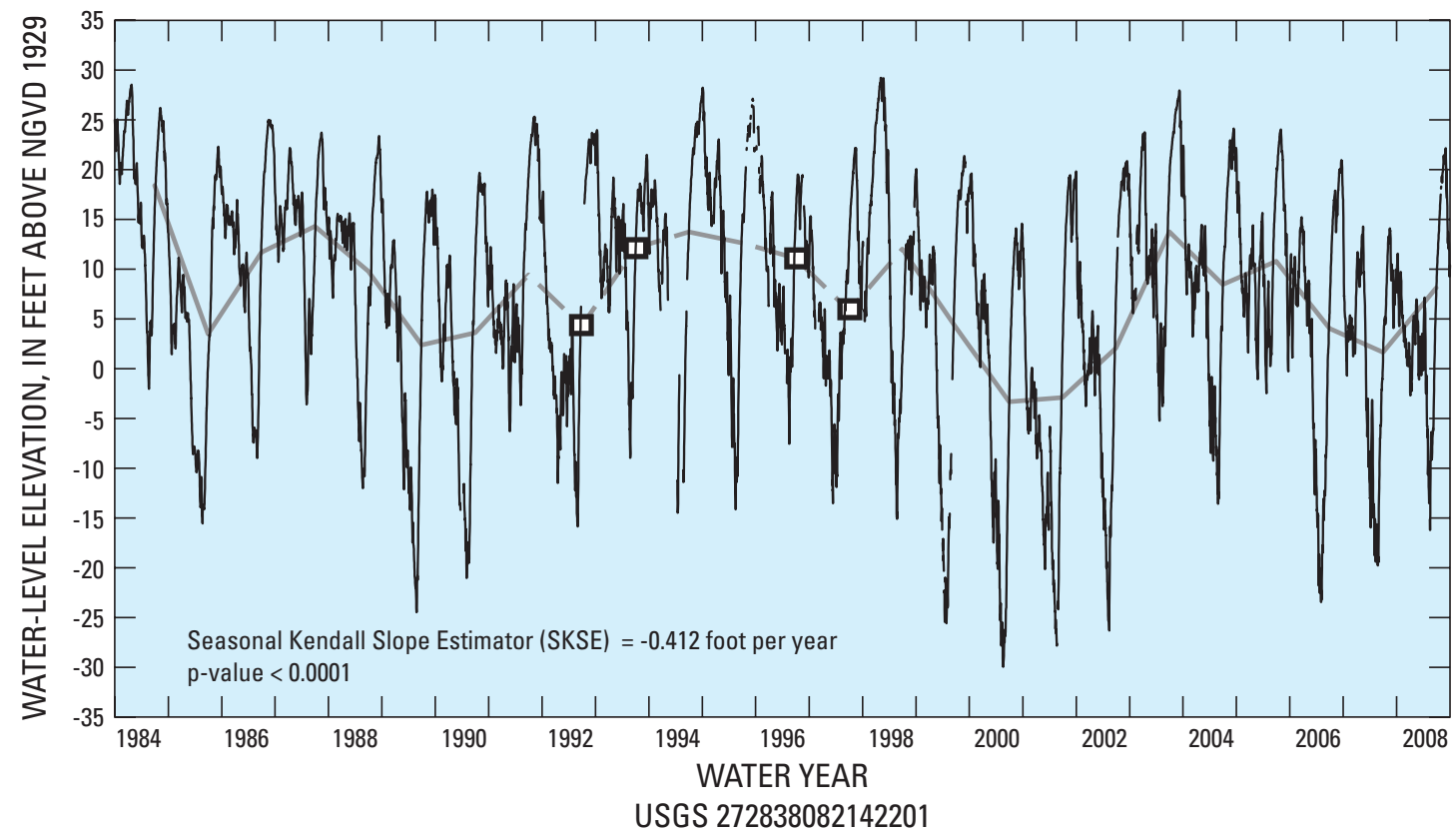

Kibler Deep Well 26B near Bethany, FL

Figure 51. Kibler deep well $26 \mathrm{~B}$ near Bethany water year 2008 daily maximum water level compared to historical water levels for the period October 1983 to September 2008, and the Seasonal Kendall Trend Test for the period October 1983 to September 2008. 


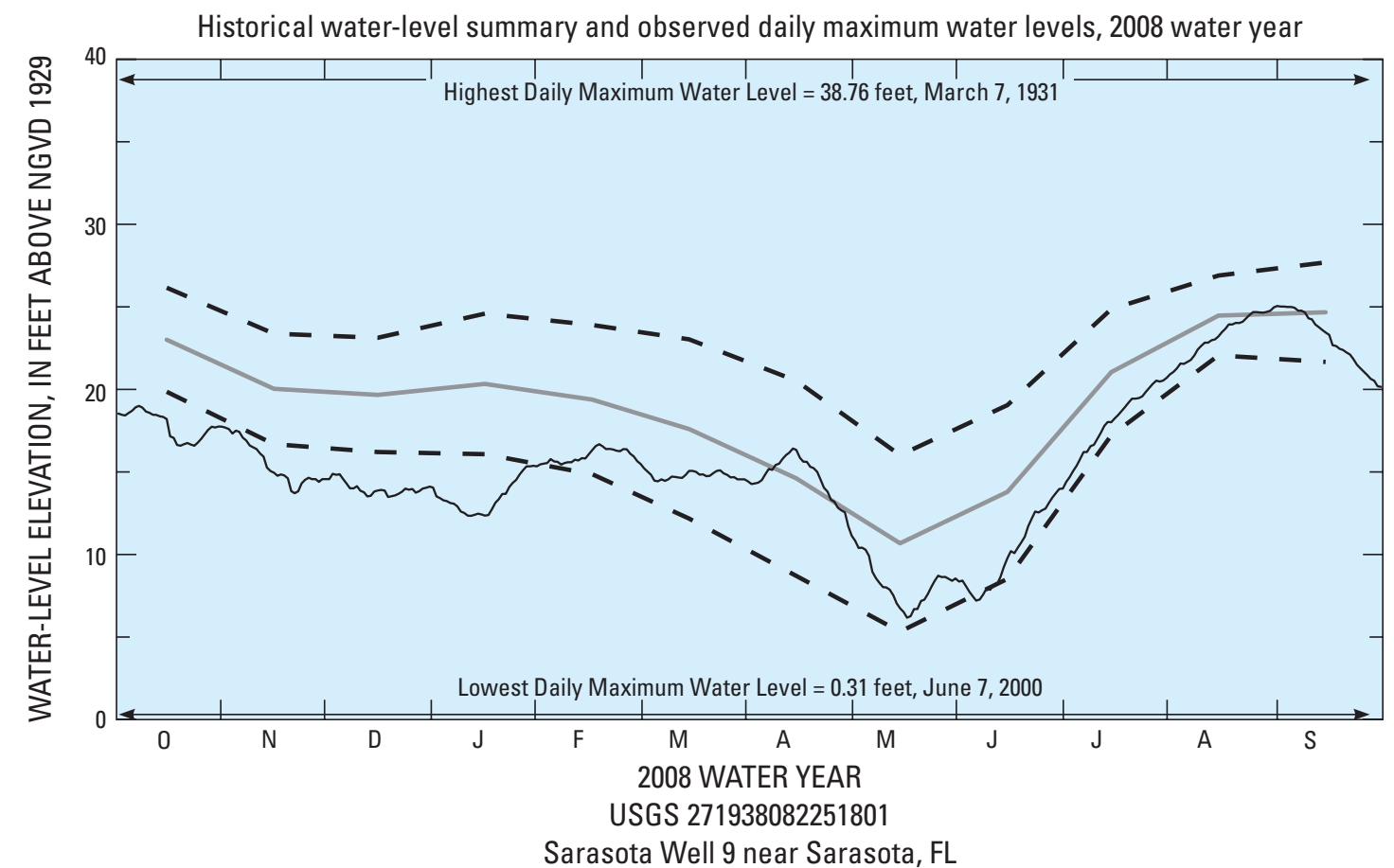

Historical daily maximum water levels, annual means of daily maximum water levels,

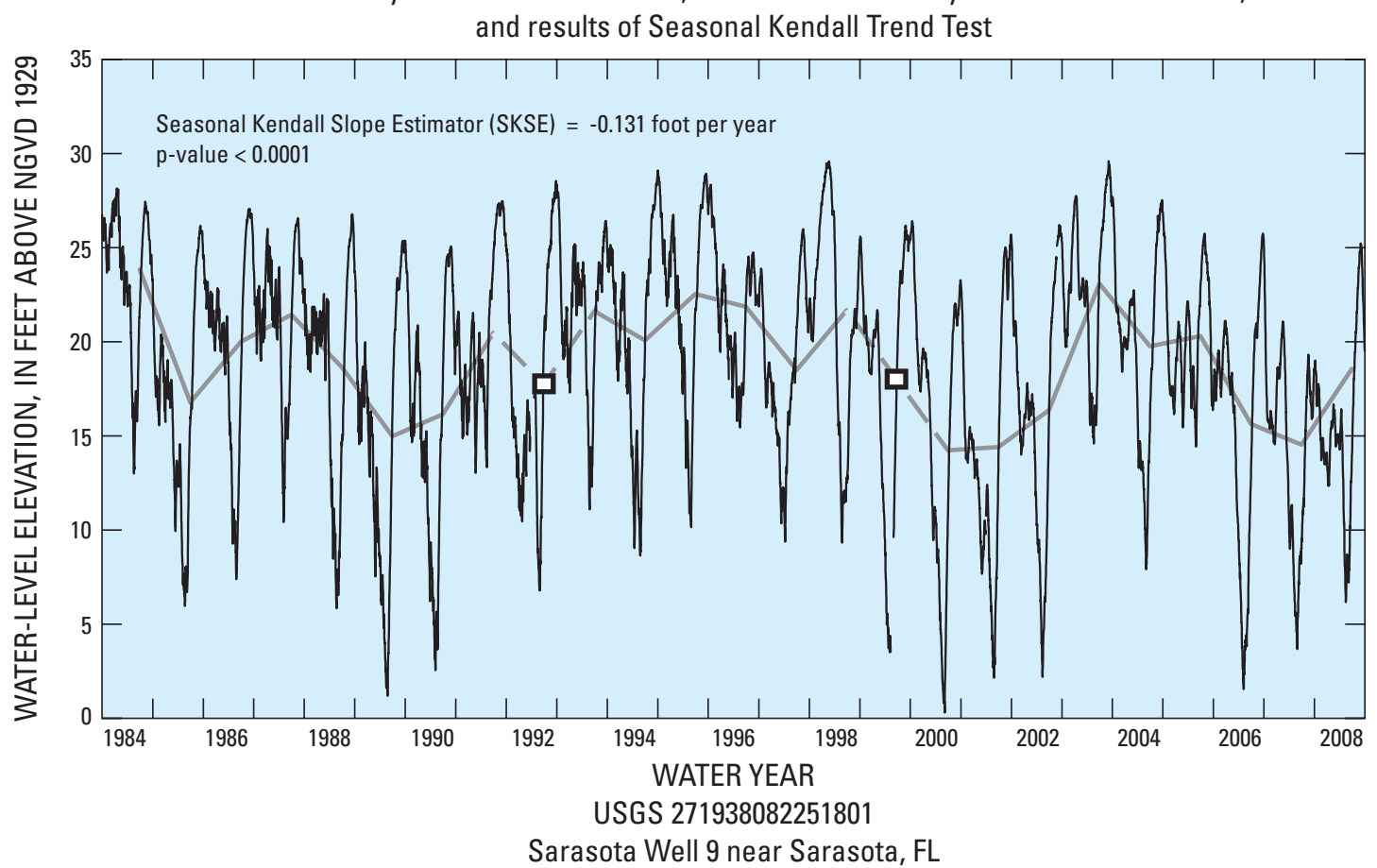

Figure 52. Sarasota well 9 near Sarasota water year 2008 daily maximum water level compared to historical water levels for the period October 1983 to September 2008, and the Seasonal Kendall Trend Test for the period October 1983 to September 2008. 


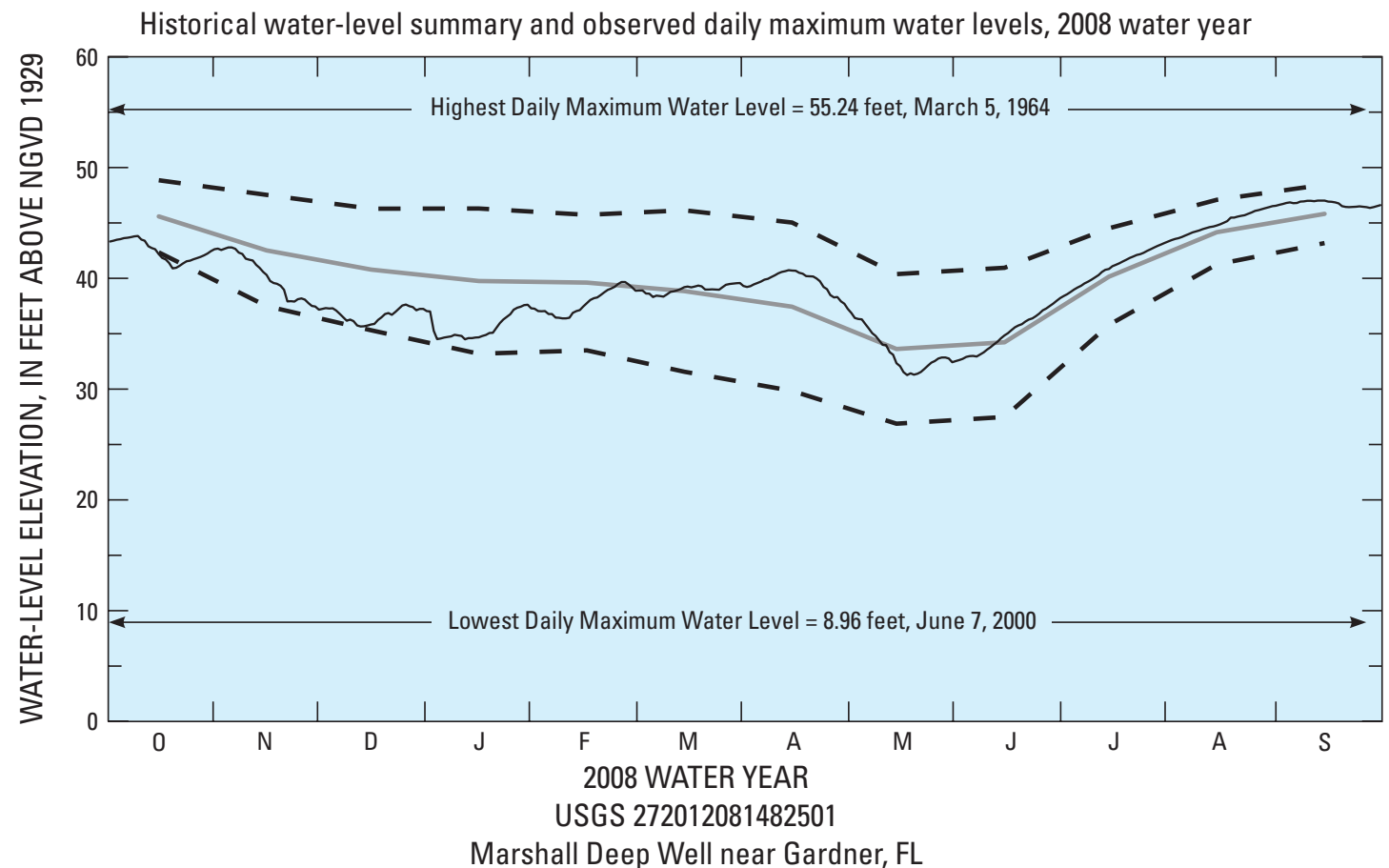

Historical daily maximum water levels, annual means of daily maximum water levels, and results of Seasonal Kendall Trend Test

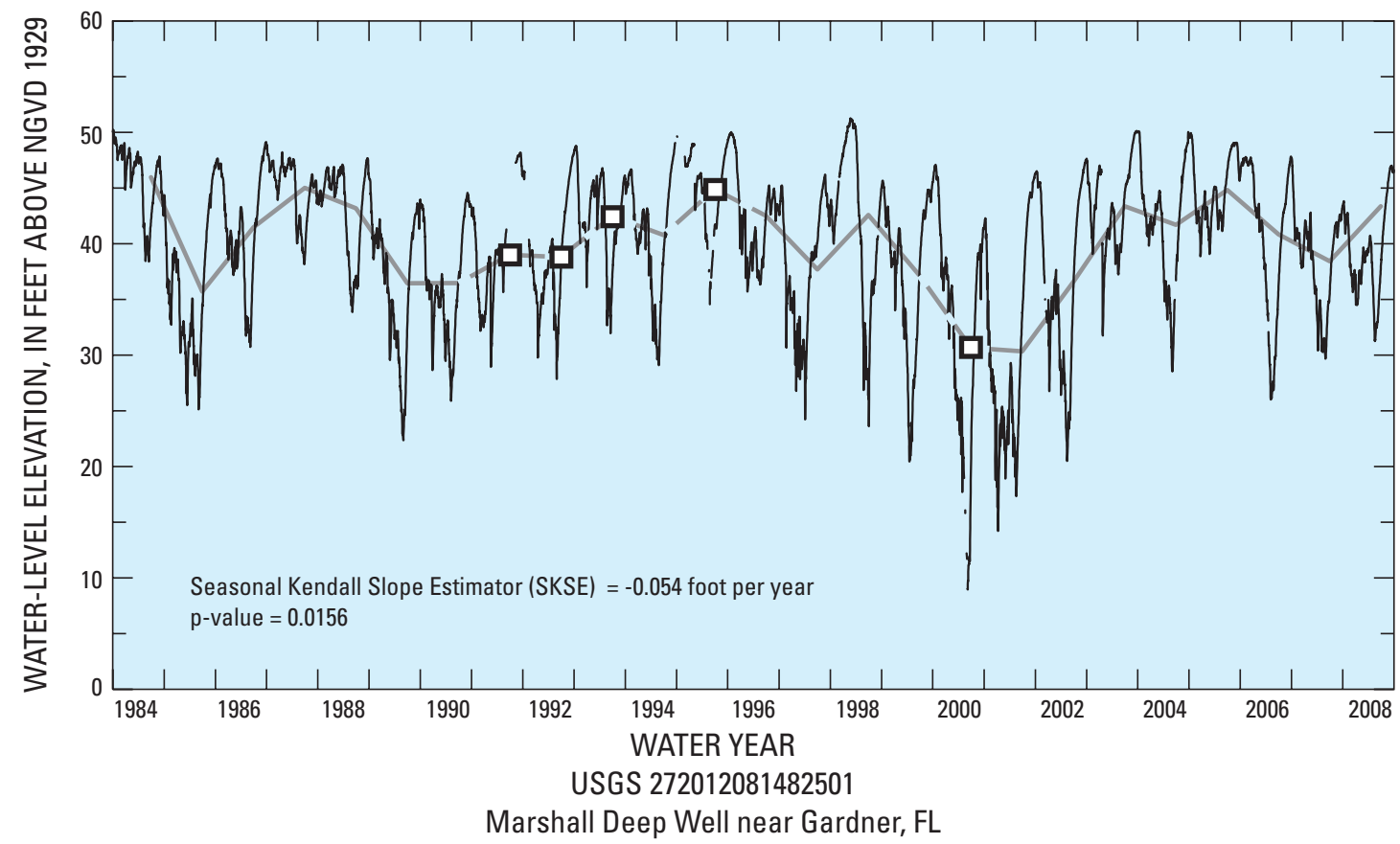

Figure 53. Marshall deep well near Gardner water year 2008 daily maximum water level compared to historical water levels for the period October 1983 to September 2008, and the Seasonal Kendall Trend Test for the period October 1983 to September 2008. 


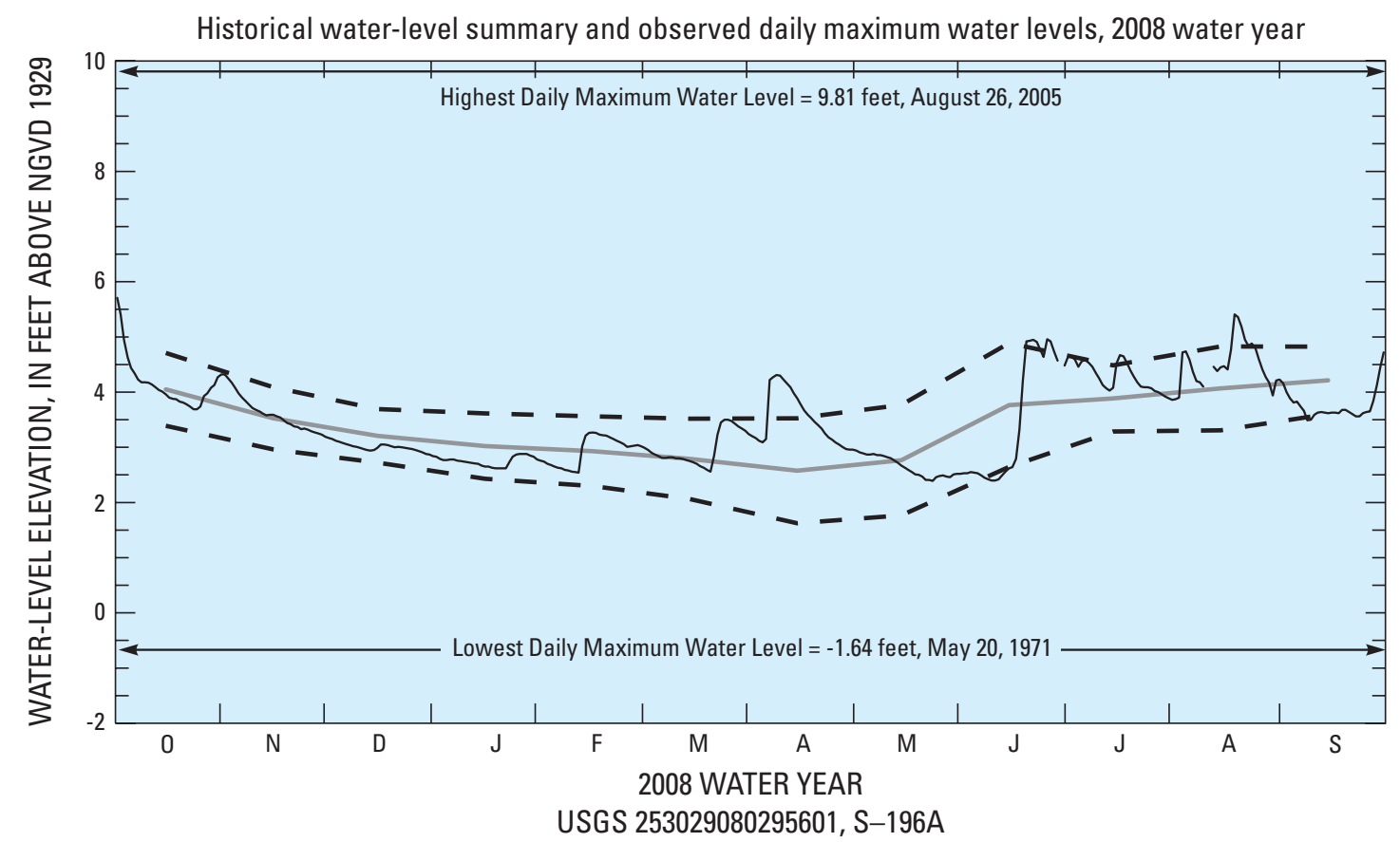

Historical daily maximum water levels, annual means of daily maximum water levels, and results of Seasonal Kendall Trend Test

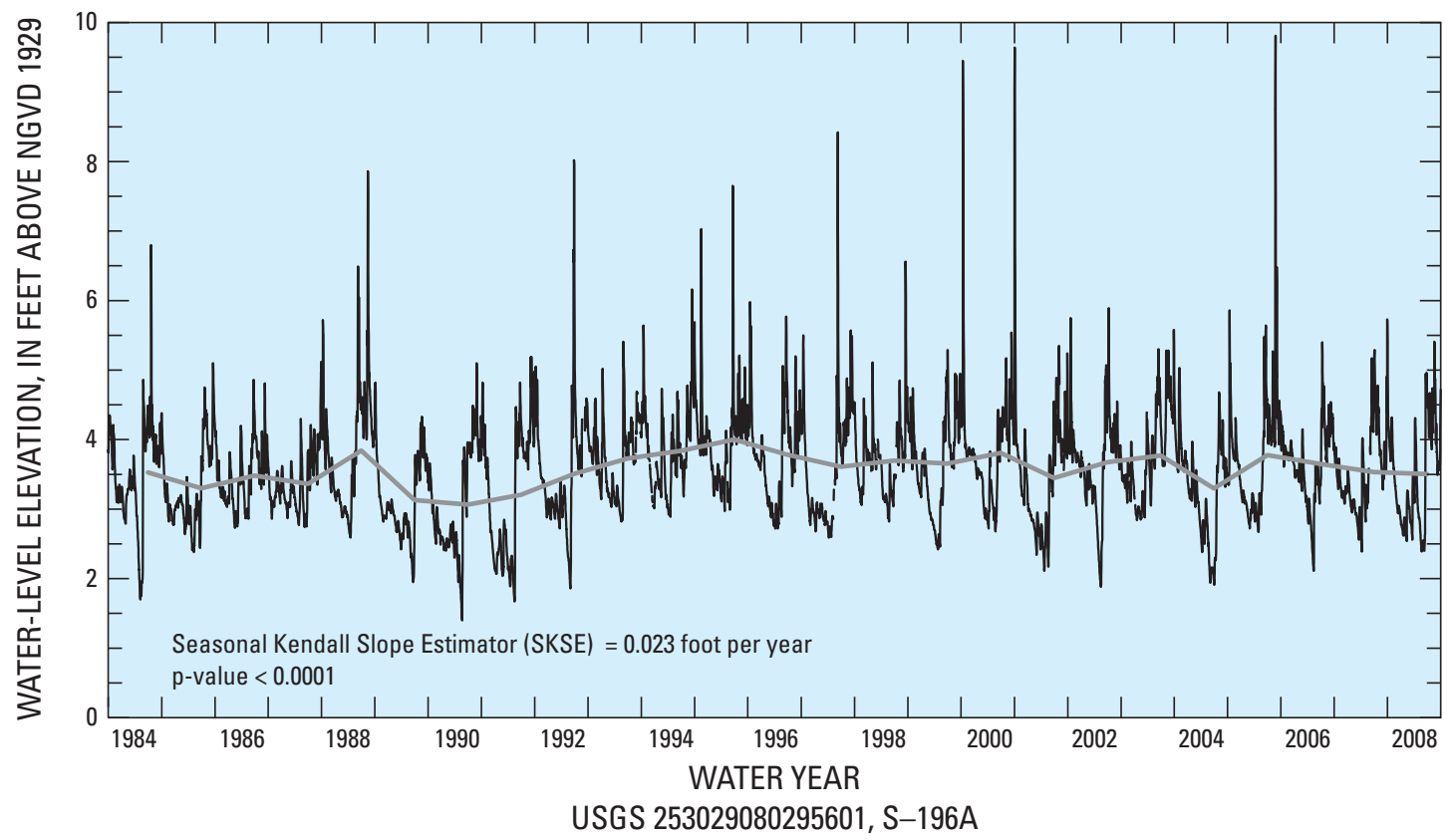

Figure 54. USGS observation well S-196A near Homestead water year 2008 daily maximum water level compared to historical water levels for the period October 1983 to September 2008, and the Seasonal Kendall Trend Test for the period October 1983 to September 2008. 


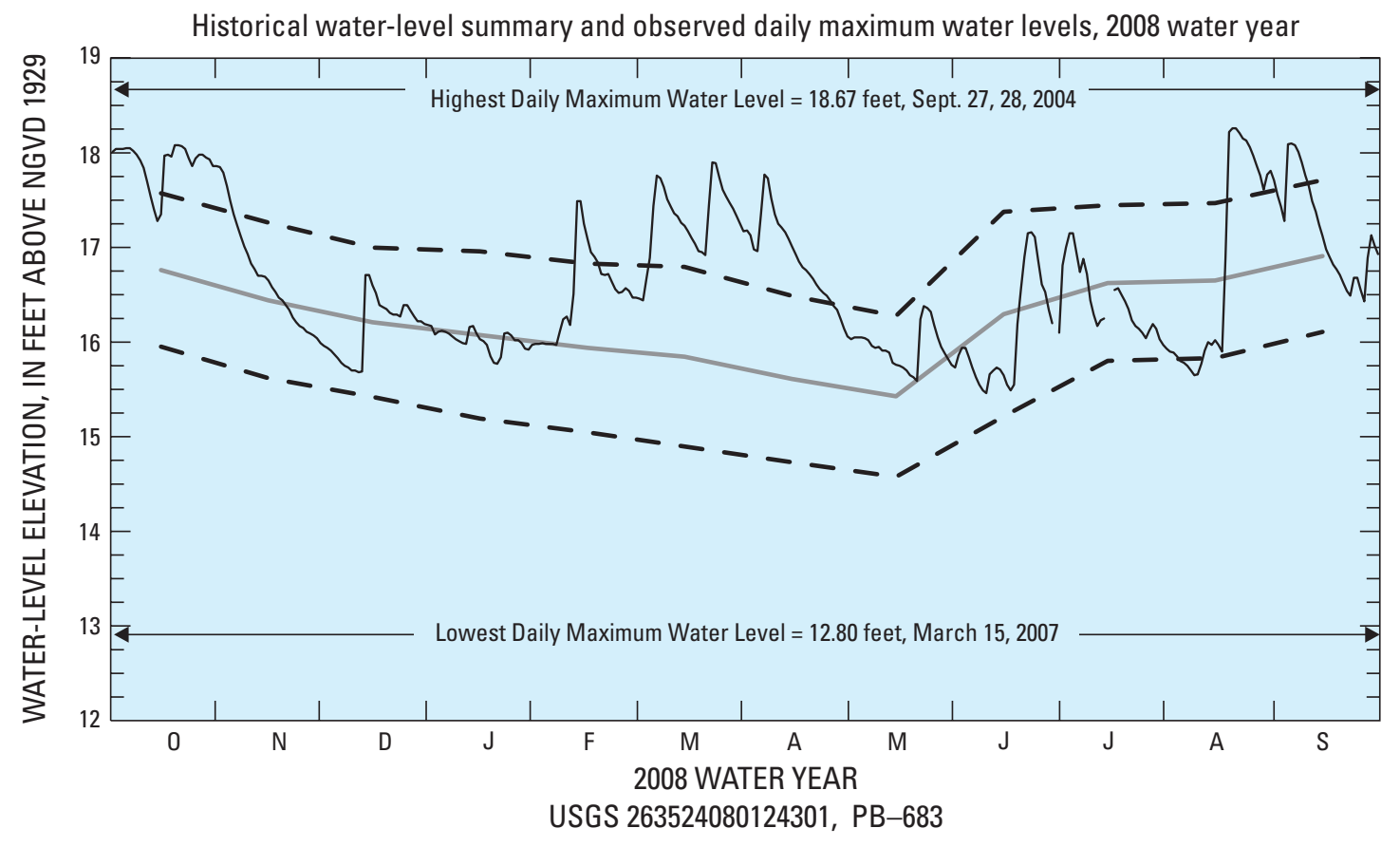

Historical daily maximum water levels, annual means of daily maximum water levels, and results of Seasonal Kendall Trend Test

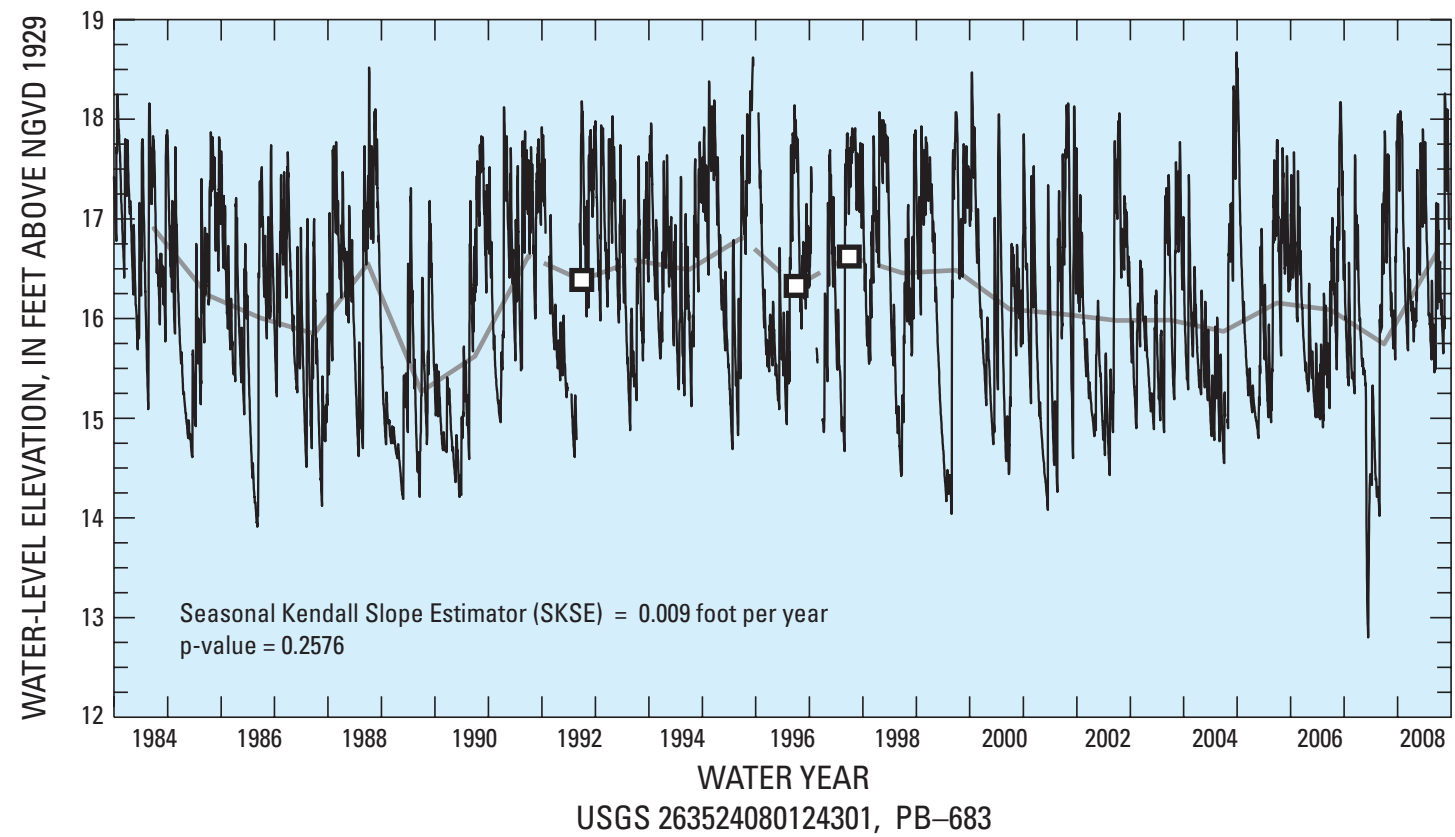

Figure 55. USGS observation well PB-683 near West Palm Beach water year 2008 daily maximum water level compared to historical water levels for the period October 1983 to September 2008, and the Seasonal Kendall Trend Test for the period October 1983 to September 2008. 


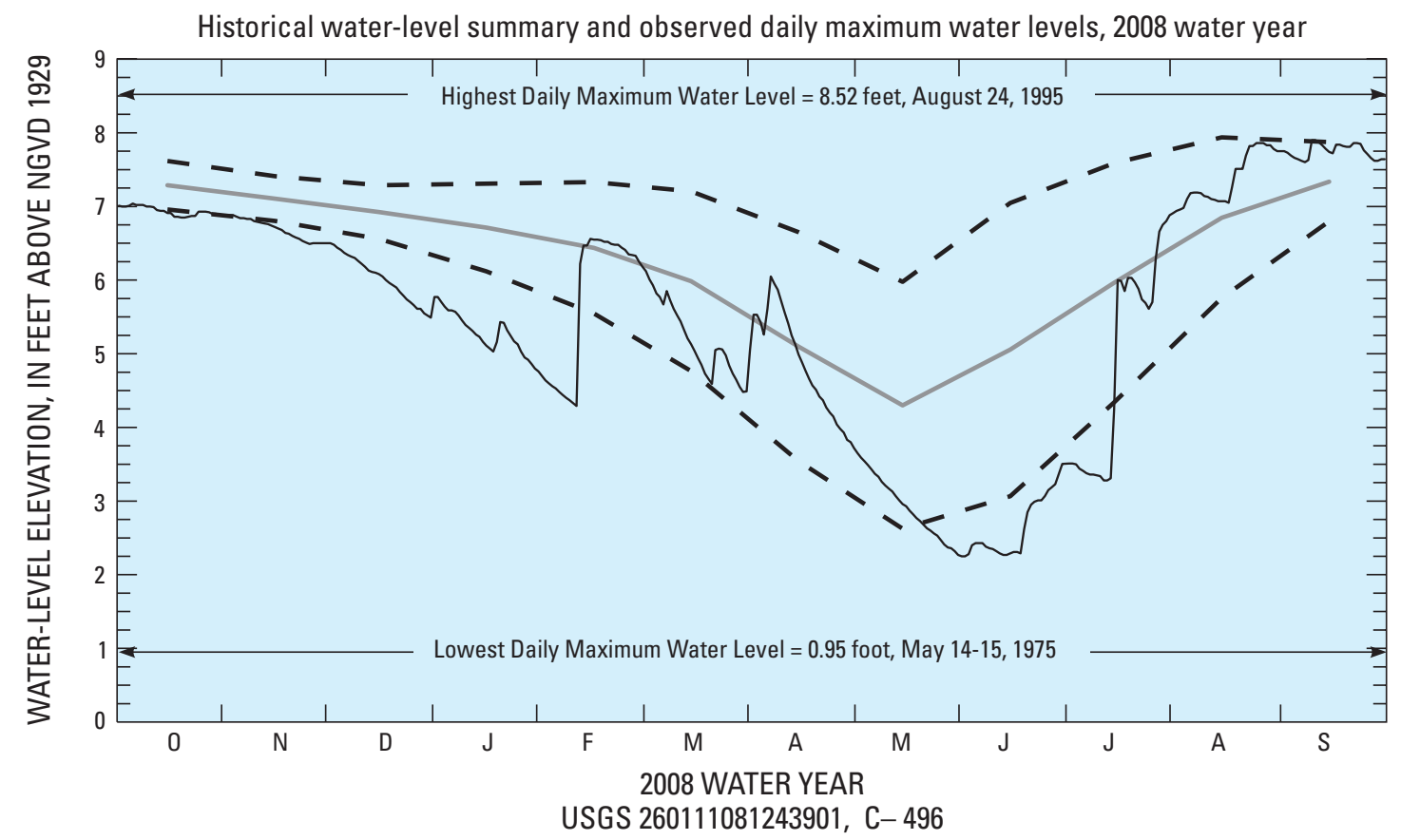

Historical daily maximum water levels, annual means of daily maximum water levels, and results of Seasonal Kendall Trend Test

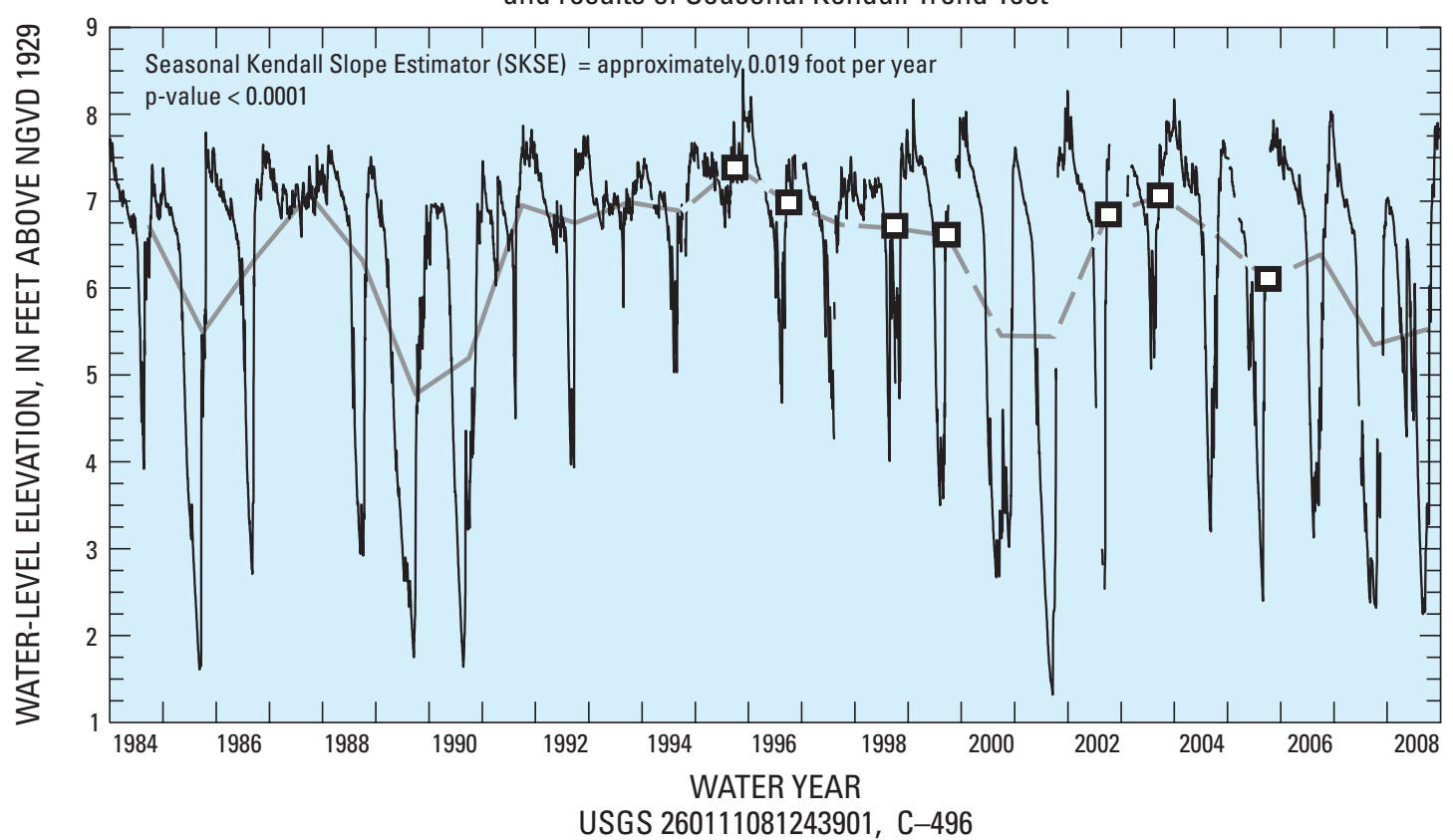

Figure 56. USGS observation well C-496 water year 2008 daily maximum water level compared to historical water levels for the period October 1983 to September 2008, and the Seasonal Kendall Trend Test for the period October 1983 to September 2008. 


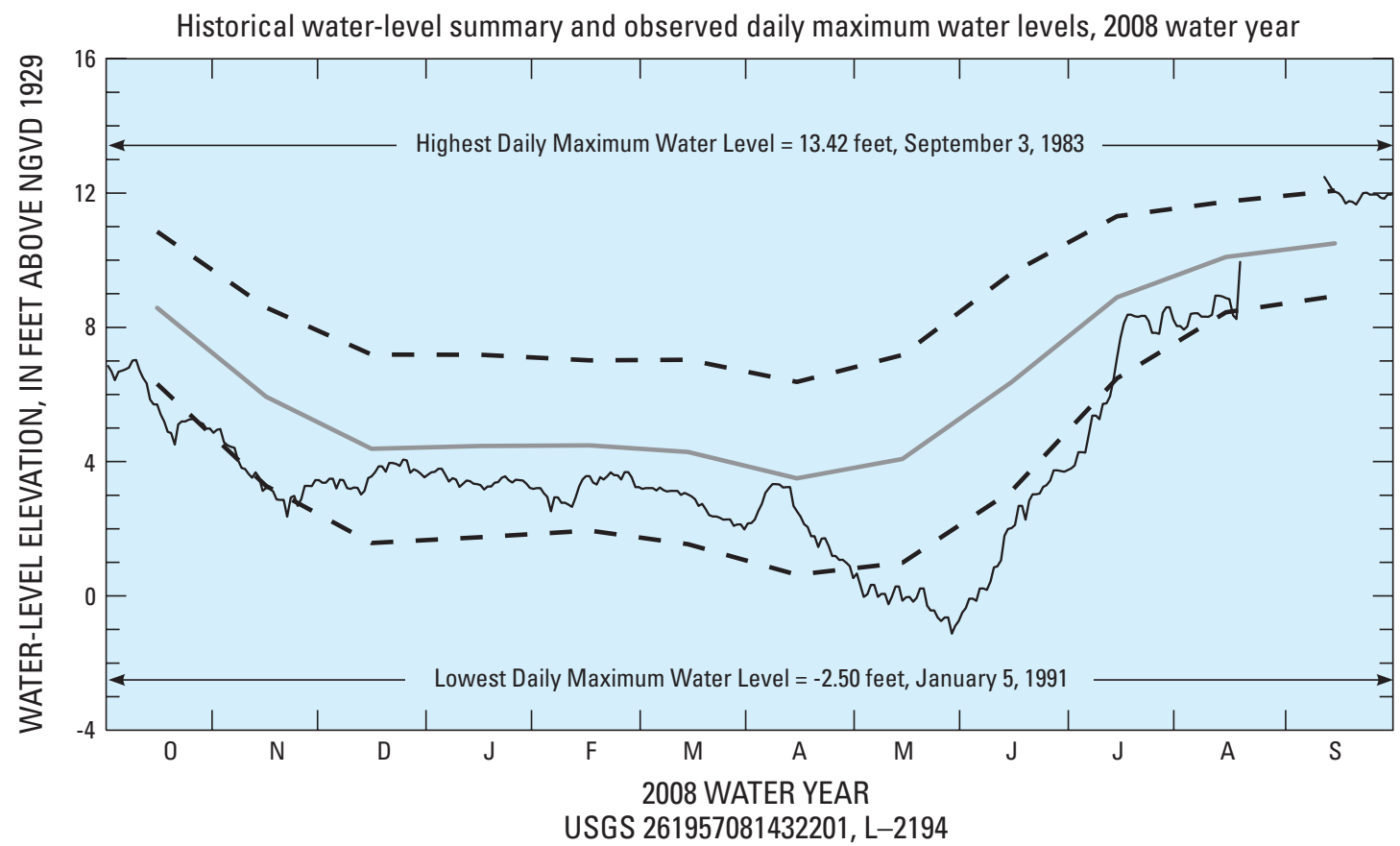

Historical daily maximum water levels, annual means of daily maximum water levels, and results of Seasonal Kendall Trend Test

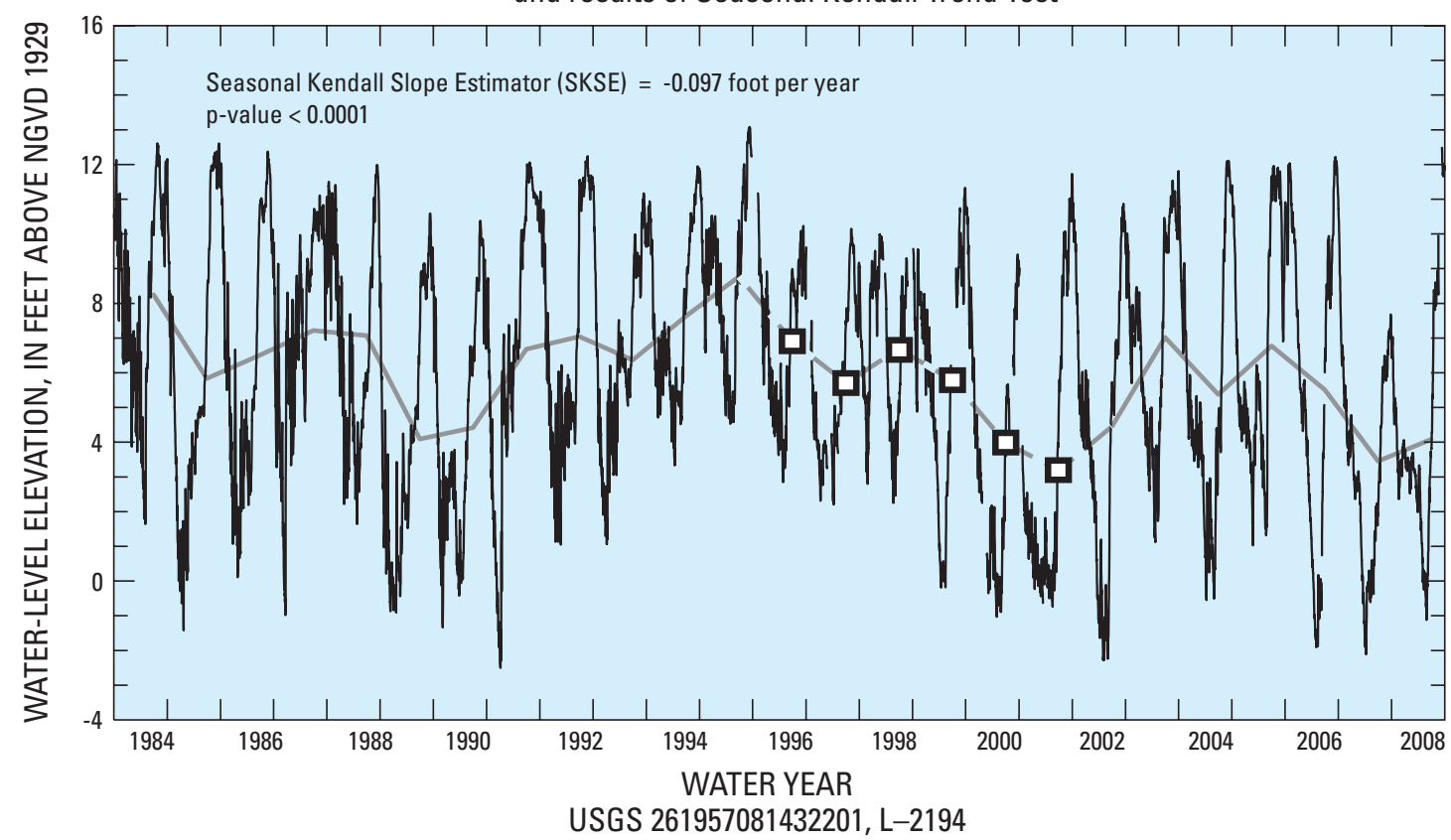

Figure 57. USGS observation well L-2194 water year 2008 daily maximum water level compared to historical water levels for the period October 1983 to September 2008, and the Seasonal Kendall Trend Test for the period October 1983 to September 2008. 


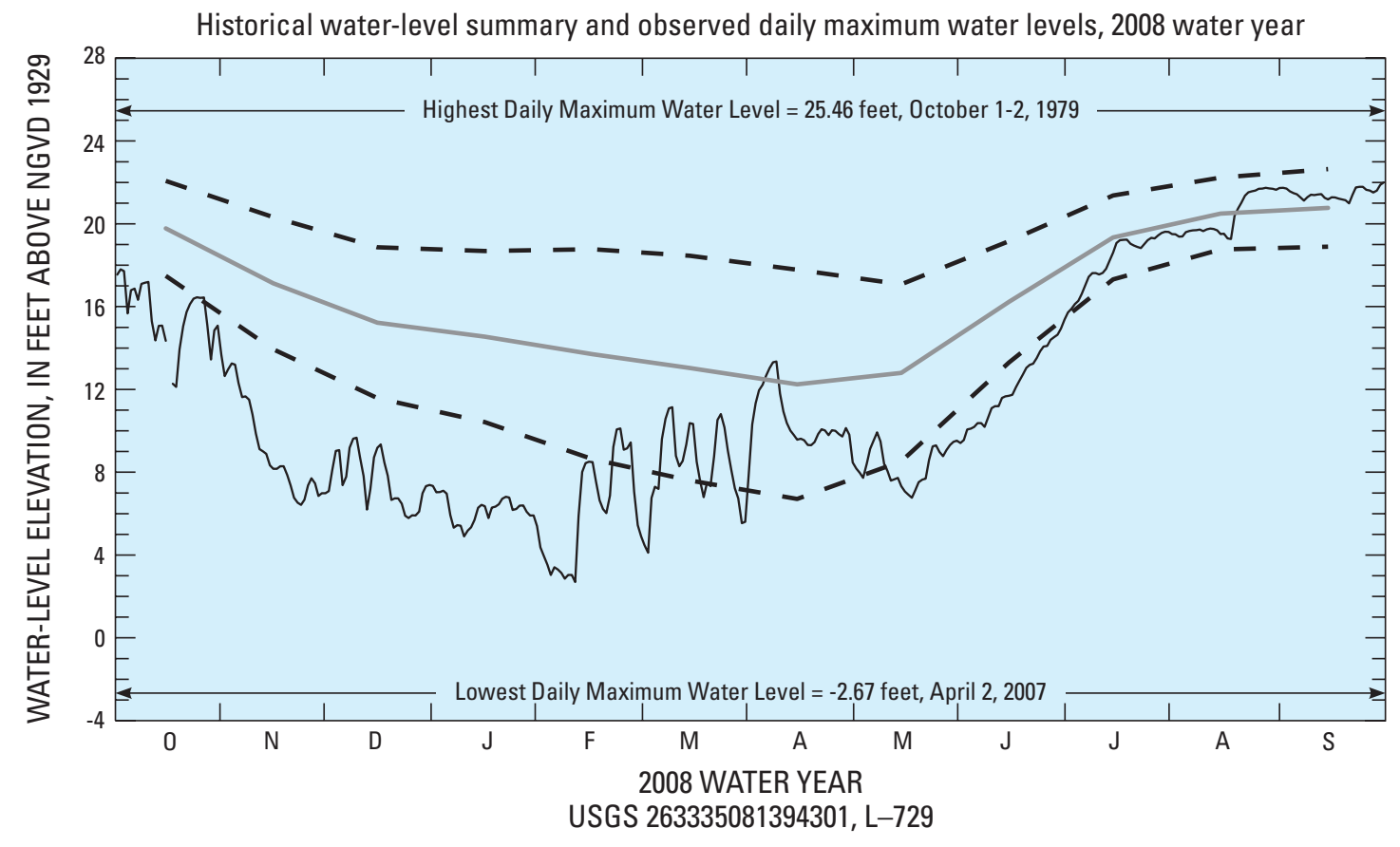

Historical daily maximum water levels, annual means of daily maximum water levels, and results of Seasonal Kendall Trend Test

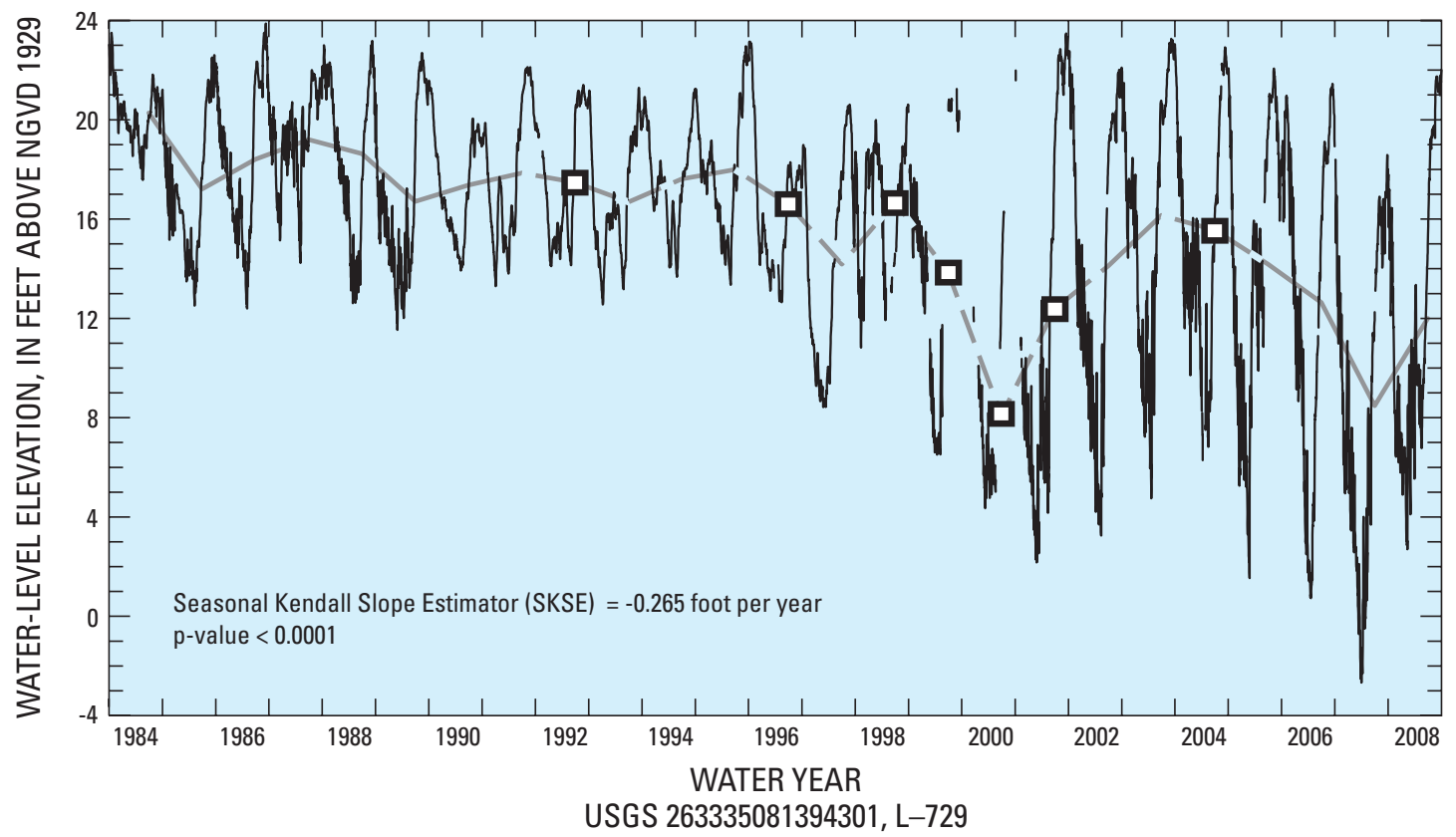

Figure 58. USGS observation well L-729 water year 2008 daily maximum water level compared to historical water levels for the period October 1983 to September 2008, and the Seasonal Kendall Trend Test for the period October 1983 to September 2008. 


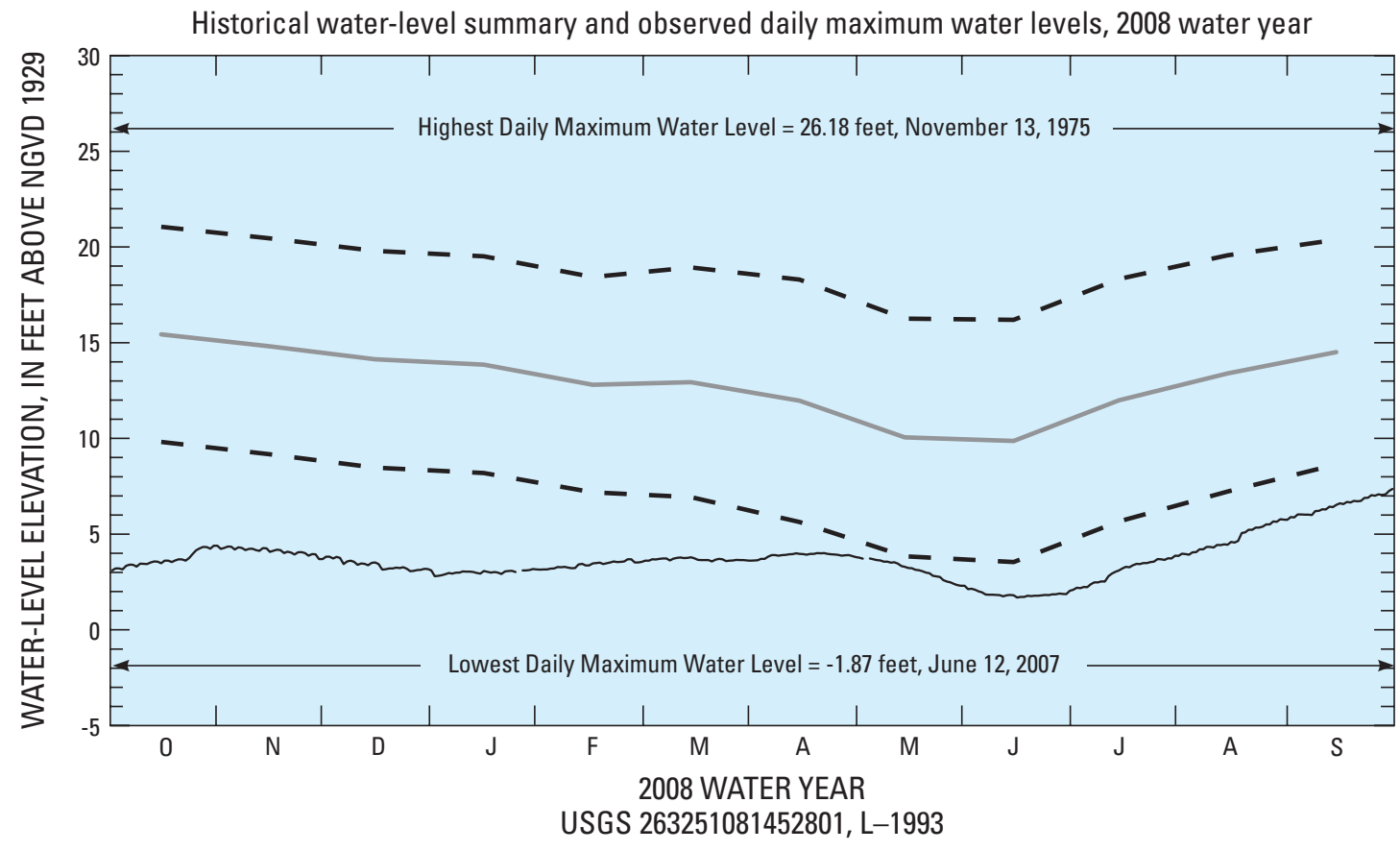

Historical daily maximum water levels, annual means of daily maximum water levels, and results of Seasonal Kendall Trend Test

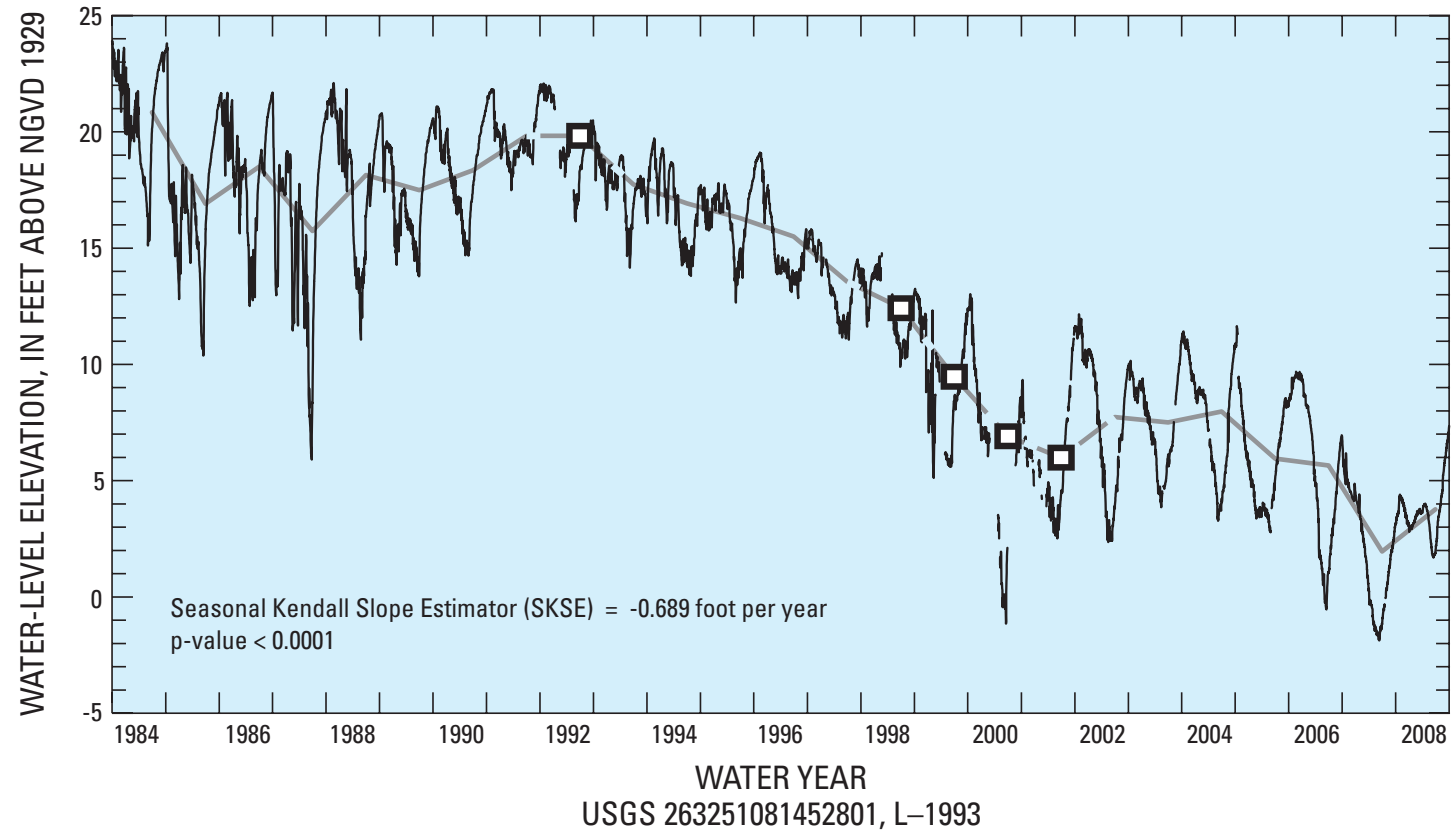

Figure 59. USGS observation well L-1993 water year 2008 daily maximum water level compared to historical water levels for the period October 1983 to September 2008, and the Seasonal Kendall Trend Test for the period October 1983 to September 2008. 


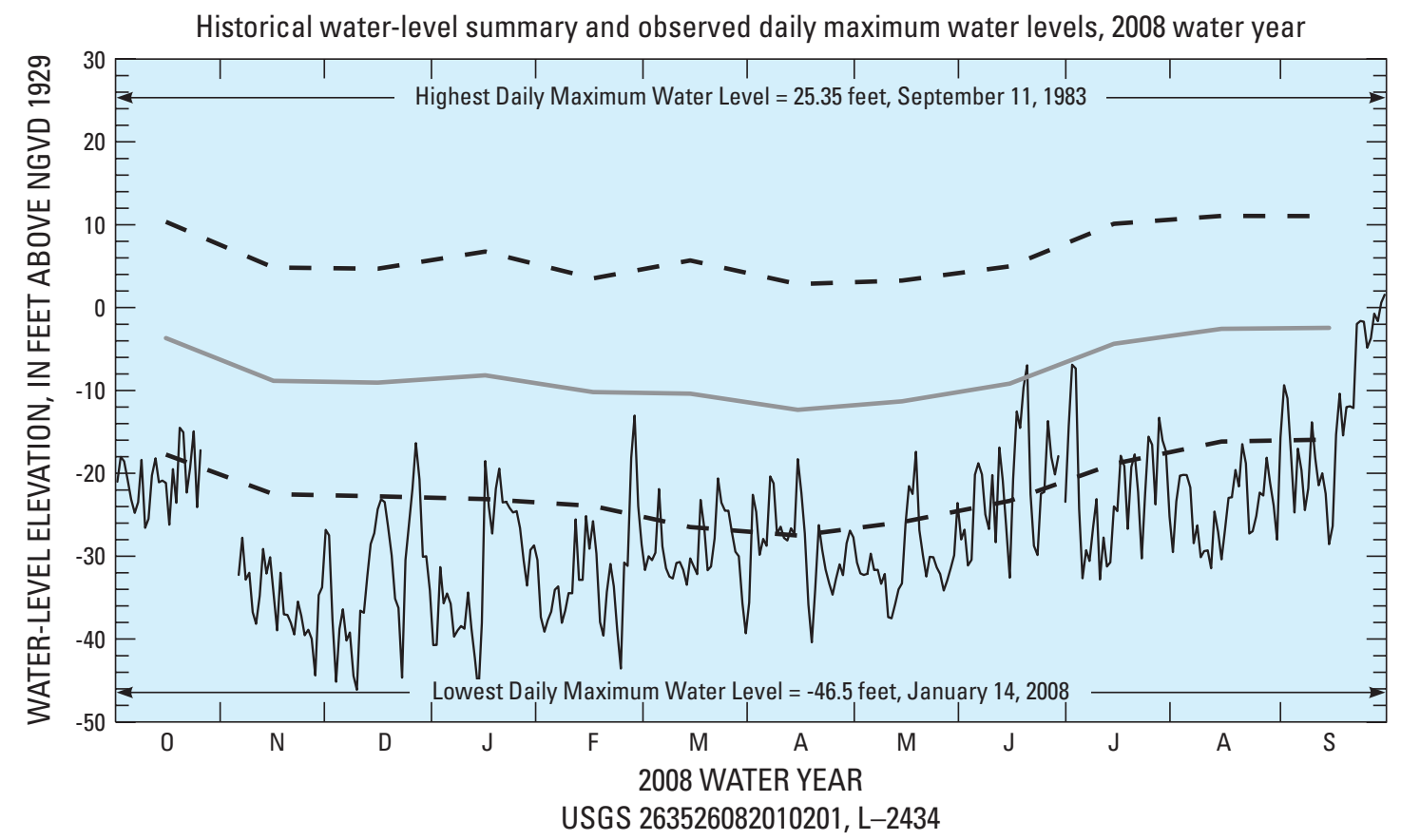

Historical daily maximum water levels, annual means of daily maximum water levels, and results of Seasonal Kendall Trend Test

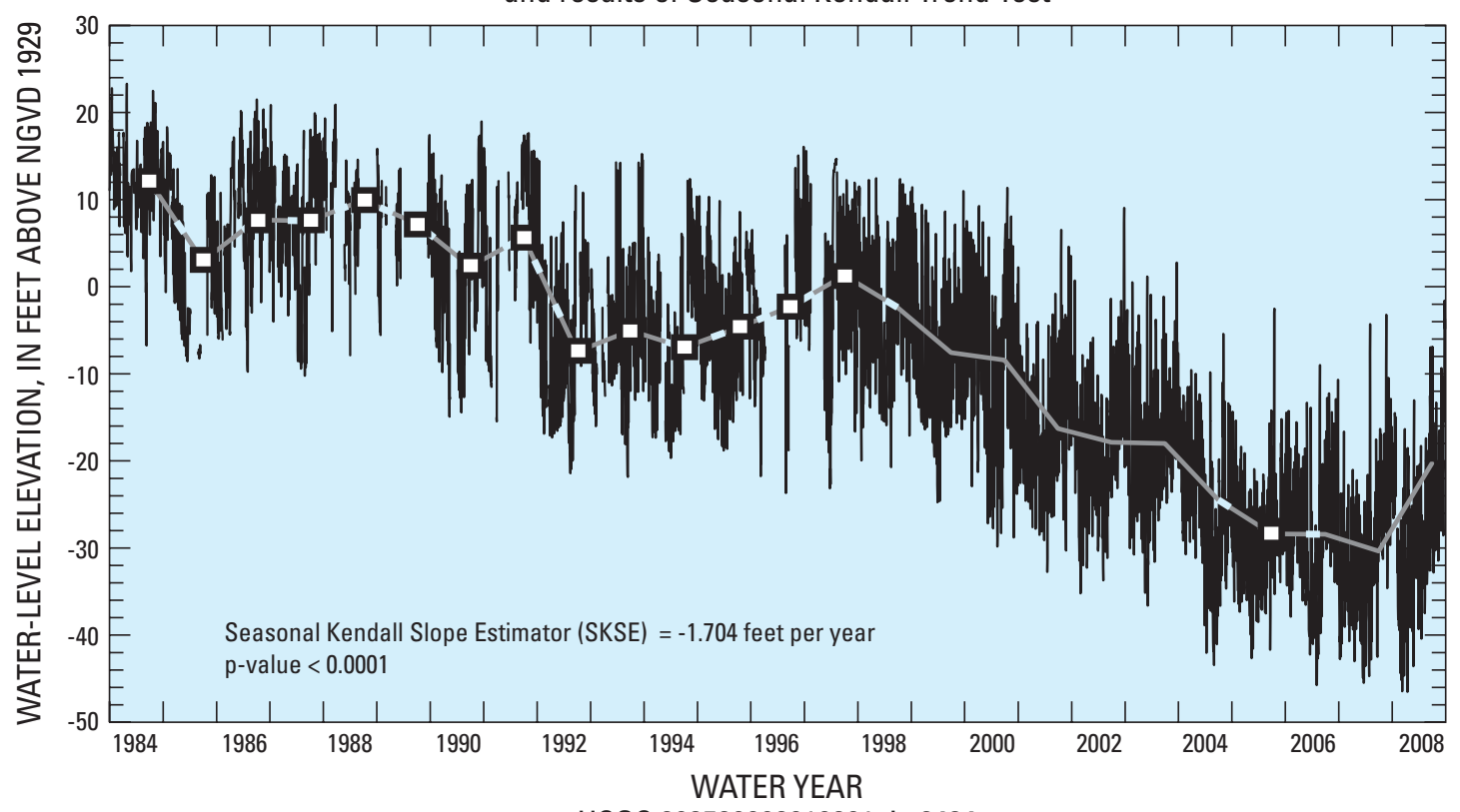

USGS 263526082010201, L-2434

Figure 60. USGS observation well L-2434 water year 2008 daily maximum water level compared to historical water levels for the period October 1983 to September 2008, and the Seasonal Kendall Trend Test for the period October 1983 to September 2008. 
The minimum daily water level for the year was recorded June 7 (60.30 ft). The maximum daily water level was recorded September $2(66.77 \mathrm{ft})$. Water levels at the Lake Oliver well (fig. 43) remained below normal throughout the entire year. The minimum daily level was recorded on June 18 (105.22 ft) and a maximum daily water level was recorded on September 1 (107.54 ft). Water-levels at the OR-47 well (fig. 44) averaged below normal from October to August, and were at a minimum on June 8-9 (51.39 ft). A significant rise in water levels in August brought levels to about normal for the remainder of the year. The maximum daily water level was recorded on September $1(61.77 \mathrm{ft})$.

Two representative wells, P-49 well near Frostproof (274812081190301; fig. 45) and H-15A well near Palmdale (270157081203101; fig. 46), each reporting water levels in the surficial aquifer system (nonartesian sand aquifer), recorded water levels below normal to above normal. Water levels in well P-49 (fig. 45) generally trended downward from about normal conditions in October and November to a minimum of $98.83 \mathrm{ft}$ on June 20, and then increased significantly to an annual maximum on August 19 of $104.85 \mathrm{ft}$, which is about normal. Well H-15A (fig. 46) water levels were below normal from October to February, and then steadily trended upward to about normal conditions in April before declining to its minimum on June 9 (55.21 ft). Water levels then rose to above normal conditions during the remainder of the year with the maximum occurring on August 19 (60.05 ft).

The significant rise in groundwater levels reported throughout northeast Florida during August and September was caused by the rainfall associated with the landfall of Tropical Storm Fay moving through the area August 19-22 (Verdi and Holt, 2010).

\section{Southwest Florida}

Groundwater levels in representative wells in southwest Florida are monitored in the Floridan aquifer system and ranged from below normal to above normal during the 2008 water year. Water levels in wells in the area were at their annual maximums in late August or early September, following the minimum levels in May or June. However, the State Highway 577 well near San Antonio (281715082164401; fig. 47) reached its minimum in January and maximum in April.

The well reporting the most daily values below normal levels was the Weeki Wachee well near Weeki Wachee (283201082315601; fig. 48), which remained below normal the entire year. The minimum daily maximum was recorded June $12(11.41 \mathrm{ft})$. The maximum daily water level occurred September 8 (15.74 ft).

ROMP 57 Floridan well near Lake Wales (275411081372001; fig. 49) reported water levels varying from below normal to above normal. The minimum daily water level at the well occurred on May 17 (93.34 ft). Maximum daily water levels occurred on September 2 (109.44 ft), and were the result of rising groundwater levels in the aquifer due to the rainfall associated with Tropical Storm Fay in August.

Water levels at the remaining five wells - State Highway 577 well near San Antonio (281715082164401; fig. 47), Turner well near Brandon (275627082150801; fig. 50), Kibler deep well 26B near Bethany (272838082142201; fig. 51), Sarasota well 9 near Sarasota (271938082251801; fig. 52), and Marshall deep well near Gardner

(272012081482501; fig. 53) all reported water levels below normal to about normal for each well. The State Highway 577 well (fig. 47) averaged below normal water levels from October through March and from late May through September. Water levels throughout April and early to mid-May were near normal. The minimum daily water level recorded during the year was on January $4(79.89 \mathrm{ft})$. The maximum daily water level recorded during the year was on April 21 $(86.24 \mathrm{ft}$ ). Turner well (fig. 50) water levels varied from below normal from October through February to about normal the remainder of the year. The maximum water level recorded occurred on September $1(18.88 \mathrm{ft})$. The minimum daily recorded water level was on June 10-11 (14.20 ft). Kibler deep well (fig 51) reported below to about normal levels during the year, with the minimum occurring in May 4 $(-1.09 \mathrm{ft})$. The maximum water level during the year was recorded on September 2 (22.15 ft) (fig. 51). Sarasota well 9 (fig. 52) averaged below normal levels most of the year, but recorded near normal levels throughout periods in April and August through September. The minimum daily water level was on May $17(6.17 \mathrm{ft})$. The maximum water level recorded during 2008 was on September 1 (25.05 ft). Marshall deep well (fig. 53) averaged near normal all year. The minimum daily water level was on May 18 (31.26 ft). The maximum water level recorded was on September 13-15 (47.01 ft).

\section{South Florida}

Groundwater levels across south Florida varied from slightly above normal to below normal, even setting new period of record lowest daily maximums at one site (figs. 54-60). Water levels at USGS observation well S-196A near Homestead (253029080295601; fig. 54) are monitored in the Biscayne limestone aquifer and were about normal during the 2008 water year. The minimum daily water level was $2.39 \mathrm{ft}$ on May 24. The maximum daily water level during the year was $5.73 \mathrm{ft}$ on October 1. Water levels in the surficial aquifer system are monitored in USGS observation well PB-683 near West Palm Beach (263524080124301; fig. 55). The minimum daily water level was below normal at $15.46 \mathrm{ft}$ on June 10. The maximum daily water level was $18.26 \mathrm{ft}$ on August 20-21. Well C-496 (260111081243901; fig. 56), which monitors water levels in the nonartesian sand aquifer of the surficial aquifer system, reported levels from below normal to near normal throughout the year. The minimum daily water level was $2.25 \mathrm{ft}$ on June 1-2. The maximum daily water level was $7.90 \mathrm{ft}$ on September 10-11. 
Water levels in the Tamiami Formation were monitored by four representative wells that recorded below normal to near normal levels during the year. USGS observation wells L-2194 (261957081432201; fig. 57), well L-729 (263335081394301; fig. 58), well L-1993 (263251081452801; fig. 59), and well L-2434 (263526082010201; fig. 60) monitor water levels in various parts of the intermediate aquifer system in south Florida. Well L-2194 (fig. 57) monitors water levels in the Tamiami Formation and recorded below normal to near normal levels during the year. The minimum daily water level was $-1.12 \mathrm{ft}$ on May 29. The maximum daily water level was $12.31 \mathrm{ft}$ on September 13. Water levels in L-729 (fig. 58), which records water levels in the sandstone aquifer, ranged from below normal to near normal throughout the year. The minimum daily maximum level was $2.70 \mathrm{ft}$ on February 11. The maximum daily level of $21.88 \mathrm{ft}$ was recorded on September 30. Well L-1993 (fig. 59), which records water levels in the Hawthorn limestone aquifer, were below normal the entire water year. The minimum daily maximum water level was $1.69 \mathrm{ft}$ on June 16 . The highest daily water level of $7.26 \mathrm{ft}$ was recorded on September 30. Water levels in the limestone aquifer in well L-2434 (fig. 60) were below normal during the year, reaching a period-of-record lowest daily water level of $-46.50 \mathrm{ft}$ on January 14 . Levels spiked to near normal conditions for a brief period in June, July, and September, recording its maximum water level of $0.60 \mathrm{ft}$ on September 30 .

\section{Summary}

This report describes hydrologic conditions for the State of Florida during the 2008 water year, including data analyses for precipitation, surface-water flow, lake elevations, and groundwater levels. Many streams in Florida recorded their record-low monthly mean discharge during the year for their periods of record, caused by a continuation of ongoing drought conditions throughout the State. For example, the Santa Fe River near Fort White, a station continuously monitored from 1927 to 1930 and 1932 to 2008, registered record-low monthly discharges in October and November. Several streams in Florida recorded their recordhigh monthly mean discharge during the year for their periods of record, caused by the landfall of Tropical Storm Fay. For example, the St. Marys River near MacClenny, a station continuously monitored since 1927, registered record-high monthly discharges in August. Lake Okeechobee, a lake monitored since 1912, reached its record-low monthly mean levels each month from October to March. Some wells across the State in various aquifers reached record-low daily maximum water levels. Well L-2434 in south Florida, which monitors the limestone aquifer, recorded its record-lowest daily maximum of $-46.50 \mathrm{ft}$ on January 14 .

\section{Selected References}

Hayes, M.J., 2008, National Drought Mitigation Center, What is Drought? Drought Indices: Web-based article accessed August 18, 2008, at http://drought.unl.edu/whatis/indicies.htm.

Helsel, D.R., and Hirsch, R.M., 1992, Statistical methods in water resources: Amsterdam, Elsevier Publishers, 529 p.

Hirsch, R.M., and Slack, J.R., 1984, A nonparametric trend test for seasonal data with serial dependence: Water Resources Research no. 20, p. 727-732.

Hirsch, R.M., Slack, J.R., and Smith, R.A., 1982, Techniques of trend analysis for monthly water quality data: Water Resources Research no. 18, p. 107-121.

Kendall, M.G., 1938, A new measure of rank correlation: Biometrika no. 30, p. 81-93.

McBride, G., 2000, Anomalies and remedies in nonparametric Seasonal Kendall trend tests and estimates: Hamilton, New Zealand, National Institute of Water \& Atmospheric Research, March 2000.

National Drought Mitigation Center, 2008, U.S. Drought Monitor, Florida: University of Nebraska Lincoln, accessed January and June 2008 http://drought.unl.edu/dm.

National Oceanic and Atmospheric Administration, Advanced Hydrologic Prediction Service, 2008 Precipitation analysis: accessed March 2009 at http://water.weather.gov/precip/

Stewart, S.R. and Beven II, J.L., 2009, Tropical Cyclone Report: Tropical Storm Fay, National Hurricane Center, accessed February 11, 2009, at http://www.nhc.noaa.gov/ pdf/TCR-AL062008_Fay.pdf.

Verdi, R.J., and Holt, S.L., 2010, Floods in Florida due to Tropical Storm Fay, August 15 through September 26, 2008: U.S. Geological Survey Open-File Report 2010-1142. 

